UNIVERSIDADE DE SÃO PAULO

FACULDADE DE ECONOMIA, ADMINISTRAÇÃO E CONTABILIDADE

DEPARTAMENTO DE ECONOMIA

PROGRAMA DE PÓS-GRADUAÇÃO EM ECONOMIA

AVALIAÇÃO DOS IMPACTOS ECONÔMICOS DE INVESTIMENTOS EM RODOVIAS SOB DIFERENTES ALTERNATIVAS DE FINANCIAMENTO

Tales Rozenfeld

Orientador: Prof. Dr. Eduardo Amaral Haddad

SÃO PAULO 
Prof. Dr. Marco Antonio Zago

Reitor da Universidade de São Paulo

Prof. Dr. Adalberto Américo Fischmann

Diretor da Faculdade de Economia, Administração e Contabilidade

Prof. Dr. Hélio Nogueira da Cruz

Chefe do Departamento de Economia

Prof. Dr. Márcio Issao Nakane

Coordenador do Programa de Pós-Graduação em Economia 


\section{AVALIAÇÃO DOS IMPACTOS ECONÔMICOS DE INVESTIMENTOS EM RODOVIAS SOB DIFERENTES ALTERNATIVAS DE FINANCIAMENTO}

Dissertação apresentada ao Departamento de Economia da Faculdade de Economia, Administração e Contabilidade da Universidade de São Paulo, como requisito para a obtenção do título de Mestre em Ciências.

Orientador: Prof. Dr. Eduardo Amaral Haddad

\section{Versão Corrigida}

(versão original disponível na Biblioteca da Faculdade de Economia, Administração e Contabilidade)

\section{SÃo PAULO}




\section{Rozenfeld, Tales}

Avaliação dos impactos econômicos de investimentos em rodovias sob diferentes alternativas de financiamento / Tales Rozenfeld. - São Paulo, 2015.

$100 \mathrm{p}$.

Dissertação (Mestrado) - Universidade de São Paulo, 2016.

Orientador: Eduardo Amaral Haddad.

1. Economia regional 2. Política de transporte 3. Equilíbrio econômico I. Universidade de São Paulo. Faculdade de Economia, Administração e Contabilidade. II. Título. 
A cachaça/Tá de graça Mas o frete/Como é que faz? (Chico Buarque) 


\section{AGRADECIMENTOS}

Existe uma série de pessoas que foram essenciais para o desenvolvimento deste trabalho. Essas pessoas mereciam diversas páginas de agradecimentos, mas, como o espaço é restrito, algumas delas serão brevemente mencionadas.

Em primeiro lugar, como não podia deixar de ser, agradeço à minha família pelo completo apoio dado ao mestrado desde os momentos iniciais, quando comecei a flertar com a ideia de mudar de área de conhecimento, guardando o recém recebido diploma de engenharia numa gaveta para mergulhar no mundo da economia. Meus pais, Cibele e Henrique, e a Tatiana, minha irmã, me deram muito suporte ao longo de toda essa empreitada.

Outro agradecimento vai à maior conquista do meu período de mestrado. A Bruna foi a paz dos meus momentos de pânico e aflição, me dando ideias quando elas me faltavam e ficando sempre ao meu lado, mesmo nos longos finais de semana que passei trabalhando enquanto o resto do mundo se divertia. Se sobrevivi a esse período, certamente foi pelo seu companheirismo, no campo pessoal, profissional, acadêmico, espiritual e qualquer outro que possa haver.

Também sou enormemente grato ao meu orientador, professor Eduardo Haddad, que foi essencial para transformar uma simples ideia em uma dissertação de mestrado. O professor Haddad esteve sempre à disposição para ouvir e discutir as minhas ideias me ajudando a selecionar os melhores caminhos para trilhar ao longo da pesquisa.

Também foram importantes para o desenvolvimento desse projeto, os professores André Chagas, Joaquim Guilhoto, Paula Pereda e Carlos Azzoni, que me deram ótimas ideias tanto para o desenvolvimento deste trabalho, quanto para suas futuras extensões dele.

Os colegas de NEREUS também foram muito importantes para o desenvolvimento deste trabalho e, em particular, agradeço enormemente ao Moisés e ao Rodrigo, que me passaram o caminho das pedras em diversas encruzilhadas e me deram ótimas dicas para a implementação deste projeto.

Também de primordial importância para a conclusão dessa empreitada foi a turma de mestrado que me acompanhou durante essa etapa da vida. Os companheiros de moradia, Bruce, Dantas e Viotti e os de parcerias em São Paulo, dentre os quais, Rafa, Ana, Bia, Artur, 
viii

Michael, Alison, Siqueira, Leo Rosa e outros, foram essenciais para tornar a experiência de mestrado muito mais divertida e agradável.

Agradeço também aos colegas da Subsecretaria de Parcerias e Inovação pela paciência durante o período de esforços paralelos entre estudos e trabalho. Em particular, agradeço enormemente a Isadora, o Rafael e a Karla pelo compartilhamento do conhecimento jurídico e sobre questões práticas da implantação de projetos de infraestrutura no Brasil. As conversas com essas pessoas foram, e continuam sendo, muito engrandecedores e agregaram bastante ao desenvolvimento deste projeto. Neste mesmo sentido, sou também muito grato à Fernanda por ter me apresentado às diversas discussões e pontos de vistas relativos às modalidades contratuais possíveis de serem utilizadas no Brasil, tendo ela, inclusive, me ajudado (mesmo sem saber) na definição inicial do escopo desse trabalho.

Por fim, agradeço a Coordenação de Aperfeiçoamento de Pessoal de Nível Superior (CAPES) pelo auxílio financeiro prestado durante o mestrado. 


\section{RESUMO}

Rozenfeld, T. (2015). Avaliação dos impactos econômicos de investimentos em rodovias sob diferentes alternativas de financiamento. Dissertação de Mestrado, Faculdade de Economia, Administração e Contabilidade, Universidade de São Paulo, São Paulo.

Este trabalho busca explorar a questão do financiamento da infraestrutura rodoviária, analisando o impacto de se financiar um projeto de melhorias em uma rodovia por meio da cobrança de pedágios vis-à-vis seu financiamento pelo incremento da alíquota do imposto sobre os salários ou do imposto sobre as vendas do setor de transportes. Utilizando um modelo de transportes sequencialmente integrado a um modelo inter-regional de equilíbrio geral computável foram simuladas as alternativas de financiamento de investimentos na rodovia BR-040, rodovia recém concedida pelo Governo Federal que figurou como estudo de caso para a presente pesquisa. Os resultados indicam que a escolha da alternativa de financiamento é relevante para os impactos regionalmente distribuídos do projeto, sendo determinante na definição das regiões beneficiadas pelas melhorias. Sob a perspectiva dos impactos agregados do país, a situação que apresenta o maior impacto no crescimento do PIB nacional é o investimento financiado pelo próprio usuário da rodovia por meio do pagamento de pedágios. Sob a perspectiva regional, percebe-se uma clara área de influência da rodovia que se beneficia de suas melhorias e, quando os custos para a execução de tais melhorias são compartilhados por todo o país por meio de uma elevação tributária, acentuam-se ainda mais os benefícios observados nessas regiões.

Palavra-chave: economia regional, política de transporte, equilíbrio econômico. 


\begin{abstract}
Rozenfeld, T. (2015). Economic impacts of road investments under different financing alternatives. Master Thesis, Faculdade de Economia, Administração e Contabilidade, Universidade de São Paulo, São Paulo.
\end{abstract}

This study explores the issue of road infrastructure funding, analyzing the impact of financing a road improvement project through tolls tariff charged from the final users vis-a-vis the financing through an increase in the country's payroll tax rate or in the tax rate on the sales of the transport sector. Using a transport model integrated to an interregional computable general equilibrium model this research simulated alternative arrangements for financing investments made at BR-040, Brazilian road recently granted by the Federal Government and which figured as the case study for this Master thesis. The results indicate that the way the investment is financed is relevant to the regionally distributed impacts of the project, being decisive in defining which regions are benefited by the improvement project. Analyzing the country's aggregated results, the situation that has the greatest impact on the Brazilian's GDP growth is the investment financed by the road users through the payment of a toll tariff. From a regional perspective, a clear area of influence that benefits from the improvements on the road can be identified and, when the costs for executing such improvements are shared with the whole country through a tax increase, these benefits are accentuated.

Keywords: regional economics, transport policy, economic equilibrium. 


\section{SUMÁRIO}

1 INTRODUÇÃ

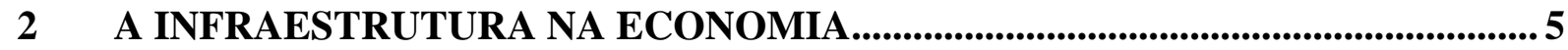

2.1 Aspectos teóricos do setor de infraestrutura ...................................................................................... 6

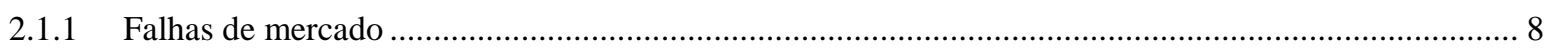

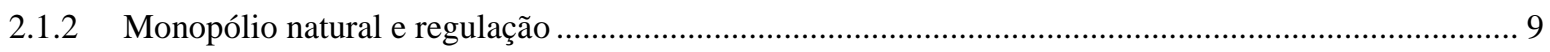

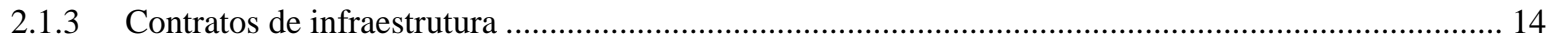

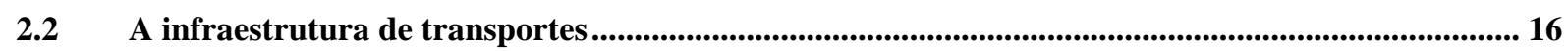

$2.3 \quad$ O setor de infraestrutura no Brasil ........................................................................................................ 19

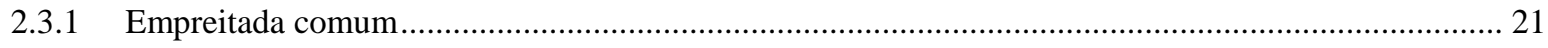

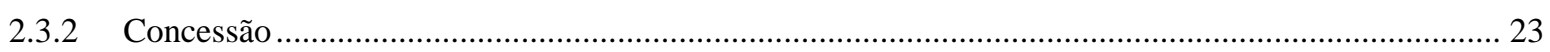

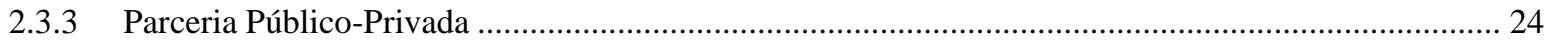

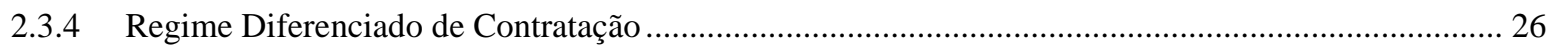

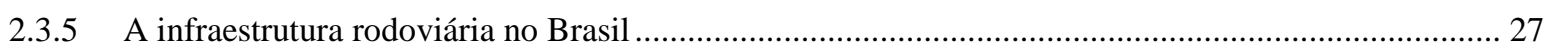

2.4 Seleção da modalidade de contratação........................................................................................................... 34

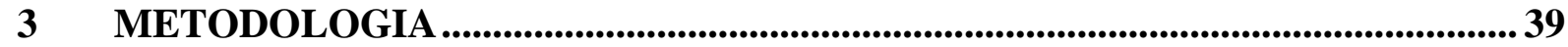

3.1 Modelo Inter-regional de Equilíbrio Geral Computável para a economia brasileira....................... 40

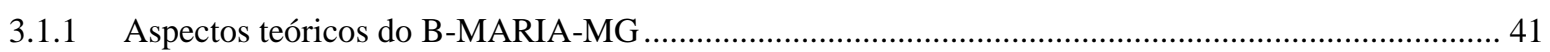

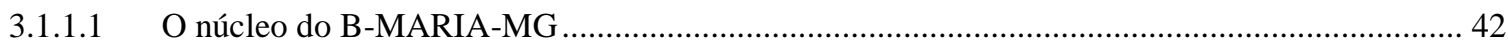

3.1.1.2 Acumulação de capital e investimento....................................................................... 47

3.1.1.3 Os custos de transporte e a demanda por bens margem ..................................................... 47

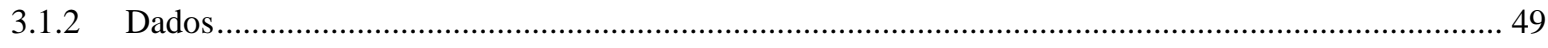

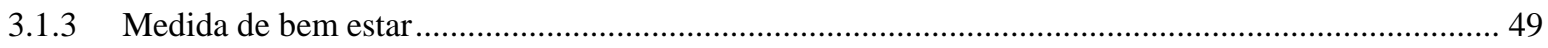

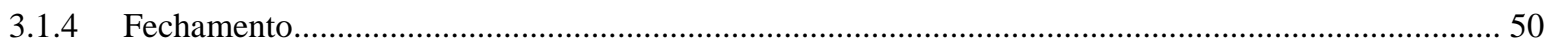

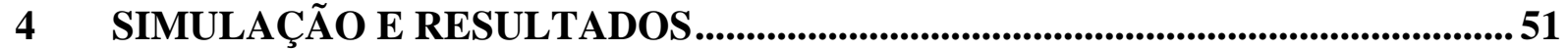

4.1 Objeto de estudo, a Rodovia BR-040...................................................................................................5 51

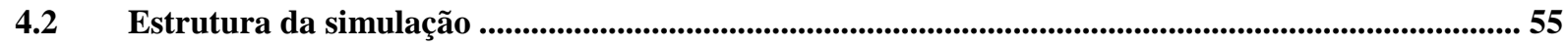

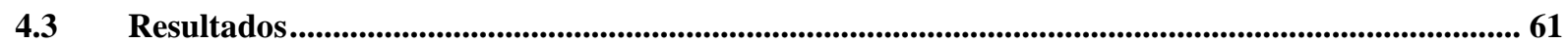

4.3.1 Relações advindas da estrutura teórica do modelo .................................................................62 62

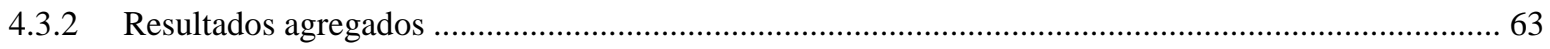

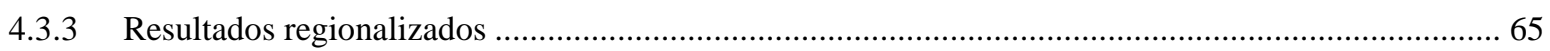

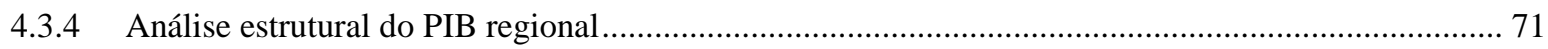

5 CONSIDERAÇÕES FINAIS .............................................................................. 73

APÊNDICE A - Crescimento por região ............................................................................85 


\section{LISTA DE TABELAS}

Tabela 1 - Classificação da infraestrutura

Tabela 2 - Contratos de concessão do PROCROFE ................................................................. 33

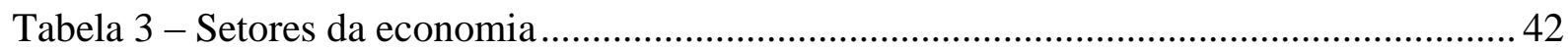

Tabela 4 - Trechos da Rodovia BR-040 entre Brasília (DF) e Juiz de Fora (MG) .................53

Tabela 5 - Incremento de custo de rodagem por tipo de rodovia ..........................................59

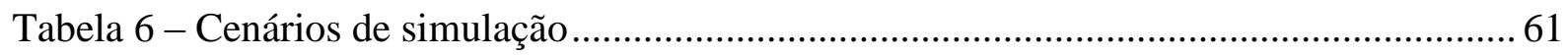

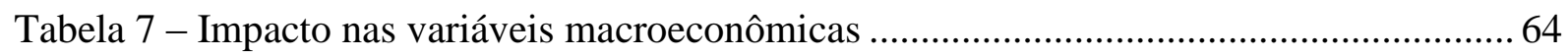

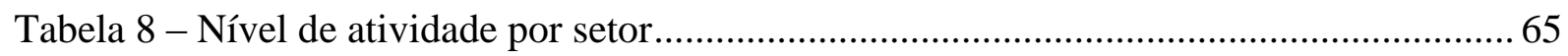

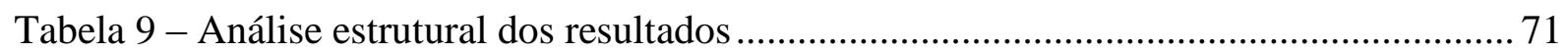

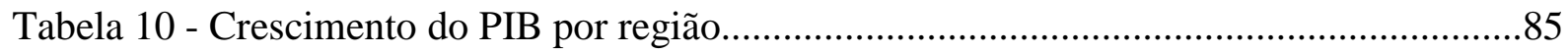




\section{LISTA DE FIGURAS}

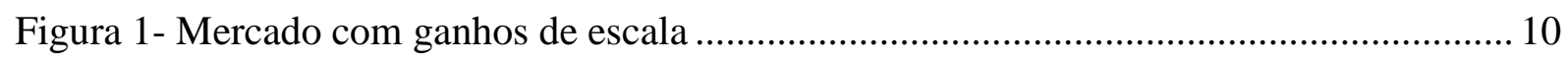

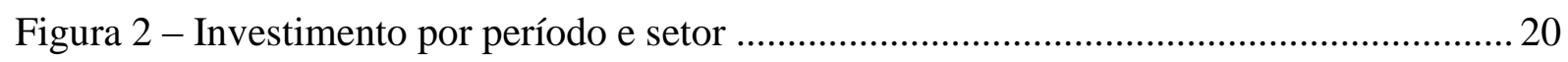

Figura 3 - Investimento recente anual por setor .......................................................... 21

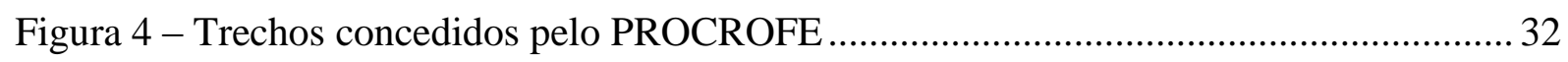

Figura 5 - Estrutura aninhada de produção .................................................................. 44

Figura 6 - Função de utilidade aninhada das famílias ......................................................... 45

Figura 7 - Estrutura de otimização dos investidores.......................................................... 46

Figura 8 - Localização da rodovia BR-040 com as praças de pedágio e Belo Horizonte em

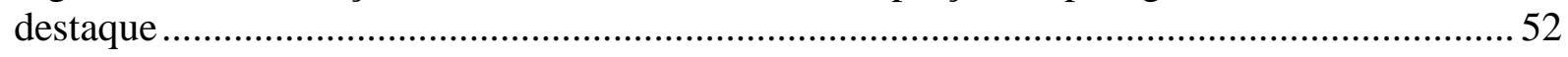

Figura 9 - Estrutura acionária e controladas da Invepar em 2013 ......................................... 55

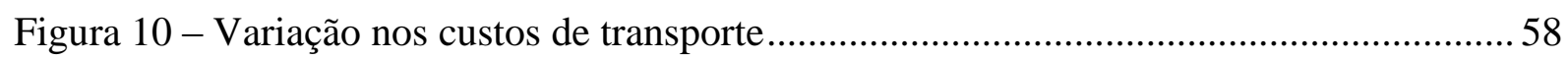

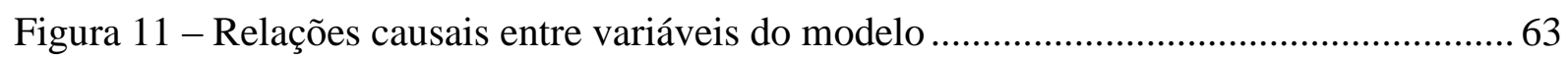

Figura 12 - Índice de variação na eficiência dos transportes sem considerar pedágio .............66

Figura 13 - Índice de variação na eficiência dos transportes considerando pedágio............... 67

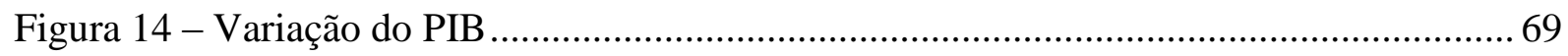

Figura 15 - Variação do consumo real das famílias .......................................................... 70 


\section{LISTA DE ABREVIAÇÕES}

ADP: Administração Pública

AGP: Agricultura

ANTT: Agência Nacional de Transportes Terrestres

B-MARIA: Brazilian Multisectoral And Regional-Interregional Analysis Model

BNDES: Banco Nacional de Desenvolvimento Econômico e Social

CES: Constant Elasticity of Substitution

CIDE: Contribuição de Intervenção no Domínio Econômico

CME: Comércio

CNT: Confederação Nacional do Transporte ou setor de Construção

DNER: Departamento Nacional de Estradas de Rodagem

DNIT: Departamento nacional de Infraestrutura de Transportes

EBP: Estruturadora Brasileira de Projetos

EGC: Equilíbrio Geral Computável

EUA: Estados Unidos da América

FND: Fundo Nacional de Desenvolvimento

FRN: Fundo Rodoviário Nacional

FOB: Free on Board

IBGE: Instituto Brasileiro de Geografia e Estatística

ICMS: Imposto sobre a Circulação de Mercadorias e Serviços

IEGC: Inter-regional de Equilíbrio Geral Computável

IND: Indústria

IPVA: Imposto sobre a Propriedade de Veículos Automotores

IUCLLG: Imposto Único sobre Combustíveis e Lubrificantes Líquidos e Gasosos

MNG: Mineração

NGE: Nova Geografia Econômica

NSW: New South Wale

O-D: Origem-Destino

OTS: Outros Serviços

PAC: Programa para Aceleração do Crescimento

PELT-MG: Plano Estratégico de Logística de Transportes de Minas Gerais

PELT-PA: Plano Estratégico de Logística de Transportes do Pará

PIB: Produto Interno Bruto 
PNLT: Plano Nacional de Logística e Transportes

P\&D: Pesquisa e Desenvolvimento

PIL: Programa de Infraestrutura Logística

PPP: Parceria Público-Privada

PROCROFE: Programa de Concessões de Rodovias Federais

RDC: Regime Diferenciado de Contratação

SNV: Sistema Nacional de Viação

SPE: Sociedade de Propósito Específico

SUS: Sistema Único de Saúde

TRN: Transportes 


\section{INTRODUÇÃO}

A literatura econômica tem mostrado que a adequada disponibilidade de infraestrutura desempenha um importante papel no desenvolvimento econômico e social de determinada região, impactando o custo dos insumos e a produtividade das firmas e do trabalho, o que tem efeito no crescimento econômico e nas desigualdades regionais. Em particular, a infraestrutura de transportes é recorrentemente indicada entre as que têm maior impacto no desenvolvimento (ASCHAUER, 1989; FERREIRA e MALLIAGROS, 1998; MUSSOLINI e TELES, 2010; CALDERÓN e SERVÉN, 2010a; CALDERÓN e SERVÉN, 2010b; GÓMEZANTONIO e FINGLETON, 2012).

Apesar de a evidência empírica apontar para a importância da infraestrutura no desenvolvimento econômico, no Brasil, esse setor permanece muito defasado para um país que figura entre as 10 maiores economias do globo. Levantamento do Fórum Econômico Mundial sobre a competitividade de 144 países em 2014 (SALA-I-MARTÍN et al., 2014) aponta que, no quesito "infraestrutura",, o Brasil encontra-se na $76^{\mathrm{a}}$ colocação, o que contribui negativamente para sua $57^{\mathrm{a}}$ posição no índice geral. No caso da infraestrutura rodoviária de transportes, o cenário brasileiro é ainda mais preocupante, uma vez que as rodovias do país ocupam a $122^{\mathrm{a}}$ posição segundo esse mesmo levantamento.

A deficiência da infraestrutura brasileira se explica, em grande parte, pelo baixo investimento, público e privado, do país nesse ativo. A partir dos anos 90, esse valor tem se situado em torno de $2 \%$ do PIB, enquanto pesquisas mostram que o investimento mínimo recomendado seria de cerca de 3\% (FAY e MORRISON, 2005). Tendo em vista a restrição orçamentária do setor público e buscando reverter o cenário de desabastecimento de infraestrutura, o marco regulatório do Brasil tem se desenvolvido no sentido de permitir uma participação cada vez maior do capital privado, o que fica evidente a partir da edição das leis de Concessões e de Parcerias Público-Privadas, em 1995 e 2004, respectivamente.

\footnotetext{
${ }^{1}$ O levantamento se baseia na análise de 12 distintos quesitos, sendo eles: (i) instituições; (ii) infraestrutura; (iii) ambiente macroeconômico; (iv) saúde e educação primária; (v) educação superior e treinamentos; (vi) eficiência no mercado de bens; (vii) eficiência do mercado de trabalho; (viii) desenvolvimento do mercado financeiro; (ix) desenvolvimento tecnológico; (x) tamanho de mercado; (xi) sofisticação dos negócios; e (xii) inovação.
} 
Um dos setores em que a participação privada é mais evidente é no transporte rodoviário, no qual a iniciativa privada já opera quase $10 \mathrm{mil} \mathrm{km} \mathrm{de} \mathrm{rodovias} \mathrm{federais} \mathrm{e} \mathrm{a} \mathrm{União} \mathrm{anunciou}$ que pretende conceder cerca de 6 mil km adicionais nos próximos anos. No modelo de concessões rodoviárias, uma concessionária fica responsável pela manutenção, operação e por determinados investimentos, sendo remunerada diretamente pelo usuário final da rodovia, mediante a cobrança de tarifas de pedágio. Além de remunerar um operador privado pelos custos de operação e manutenção infringidos pelos veículos que utilizam as rodovias, a cobrança de pedágio pode ser considerada um instrumento para onerar os usuários pelas externalidades negativas que eles provocam na sociedade, como, por exemplo, o custo de congestionamento provocado por mais um carro na rodovia, o custo da poluição, um maior risco de acidente, etc. (DE RUS e ROMERO, 2004; NEWBERY, 2005).

Assim como em diversos países, a concessão de rodovias para a iniciativa privada tem se tornado cada vez mais comum no Brasil, surgindo como uma tendência do Governo Federal para a expansão, recuperação, operação e manutenção da infraestrutura rodoviária, dessa forma, torna-se essencial avaliar os diversos impactos econômicos desse tipo de iniciativa. Muito embora a questão central avaliada na concessão de rodovias refere-se à capacidade da receita de pedágios remunerar um investidor privado, uma questão muito relevante, que, por vezes, é pouco explorada, é se o benefício social líquido dessa política justifica a cobrança de pedágios na rodovia (NEWBERY, 2000 apud DE RUS e ROMERO, 2004).

Quando os custos de investimento, operação e manutenção de determinada rodovia são financiados mediante a cobrança de tarifas de pedágio, o usuário da estrada, maior beneficiário de sua boa condição de rodagem, se responsabiliza pelo financiamento. Em oposição, na situação em que o governo financia tais custos com recursos orçamentários, todo contribuinte acaba pagando parte desse custo, usufruindo ele da rodovia ou não. O interesse do presente estudo é avaliar os impactos econômicos dessas diferentes fontes de recursos para o financiamento de melhorias nas condições de rodagem de uma rodovia.

A construção, operação e manutenção de rodovias pelo setor privado pode trazer uma série de diferenças em relação à provisão pública dos mesmos serviços. Dentre essas diferenças, destacam-se: (i) a eficiência construtiva e de operação; (ii) a utilização de fundos privados, sem onerar o orçamento público; (iii) a rentabilidade dos projetos selecionados; (iv) o custo do financiamento; (v) a fonte dos recursos que financiam as diferentes etapas do projeto 
(projeto básico e executivo, construção, operação, manutenção, etc.); entre outros. Neste trabalho, o único ponto analisado relaciona-se ao último levantado, qual seja, a fonte dos recursos que custeiam cada etapa do projeto rodoviário. Nesse sentido, o objetivo deste trabalho é comparar um modelo de concessão, em que o usuário direto é quem arca com os custos de melhorias na rodovia, com um modelo em que os custos são todos financiados por recursos orçamentários de um governo central. Uma vez que não se pretende analisar outros aspectos que diferenciam o fornecimento público ou privado dos serviços rodoviários, a alternativa ao modelo de concessão sendo avaliada neste trabalho se aproxima de um modelo de financiamento por meio de pedágio sombra (shadow toll), bastante comum em alguns países europeus. Neste modelo, um operador privado é remunerado conforme a demanda da rodovia, porém, ao invés de cobrar pedágio do usuário direto, cobra tal tarifa diretamente do poder público.

Para comparar os impactos econômicos espacialmente distribuídos advindos das diferentes fontes de recursos para o financiamento de melhorias rodoviárias, o presente estudo se vale do modelo inter-regional de equilíbrio geral computável desenvolvido em Haddad (2004), já bastante testado para a avaliação de políticas de transporte, tanto no Brasil, quanto em outros países. A avaliação será feita com base em um estudo de caso de uma rodovia recém concedida para a iniciativa privada pelo Governo Federal, a saber, um trecho da rodovia BR040 que liga Brasília ao Rio de Janeiro. ${ }^{2}$

Após essa introdução, o próximo capítulo traz uma revisão da literatura, tanto sob uma perspectiva teórica, quanto empírica, dos impactos da infraestrutura na economia. Em seguida, no terceiro capítulo, apresenta-se o modelo inter-regional de equilíbrio geral. No quarto capítulo, apresenta-se o estudo de caso que será trabalhado, a estratégia de simulação e os principais resultados encontrados. O quinto capítulo, traz as considerações finais do trabalho com algumas sugestões de continuidade para a presente pesquisa.

\footnotetext{
${ }^{2}$ A rodovia BR-040 liga Brasília ao Rio de Janeiro, porém o trecho que será estudado parte da capital do país e vai apenas até Juiz de Fora (MG), pois este é o trecho que foi recentemente concedido. O trecho de Juiz de Fora ao Rio de Janeiro já é operado pela iniciativa privada desde 1995.
} 


\section{A INFRAESTRUTURA NA ECONOMIA}

Aschauer (1989) foi pioneiro em sugerir que a produtividade de um país está relacionada ao seu estoque de infraestrutura, e, a partir desse trabalho, diversos autores passaram a buscar os impactos econômicos da infraestrutura. Calderón e Sérven (2010a) avaliam que, durante os anos 1980 e 1990, abriu-se uma lacuna entre o estoque de infraestrutura dos países latino americanos e o de outros países em desenvolvimento. O baixo investimento nos países da América Latina no período é parcialmente explicado pelos desequilíbrios macroeconômicos e pelas necessidades de ajuste fiscal. Avaliando o caso brasileiro, o estudo de Ferreira e Malliagros (1998) encontra uma forte relação entre a infraestrutura e produto de longo prazo, e, em particular, avaliam que, apesar de o estoque de capital no setor de transportes como um todo apresentar uma alta elasticidade-renda de longo prazo $(0,57)$, o impacto do capital rodoviário parece ser menor que o de ferrovias e portos. Em relação aos investimentos, os autores estimam que o setor de transportes é o mais significativo, apresentando uma elasticidade-renda de 0,463, seguido pelo investimento em energia e as telecomunicações.

Ao elaborar uma meta-análise da elasticidade-produto encontrada por diversos trabalhos, Melo et al. (2013) avaliam o impacto que a infraestrutura exerce na economia. Avaliando 563 elasticidades obtidas em 33 estudos diferentes, os autores concluem que algumas escolhas do pesquisador são relevantes nas elasticidades encontradas, entre elas, destacam-se: método econométrico, correção de causalidade reversa por variáveis instrumentais, possível viés de variável omitida (urbanização, transbordamento espacial, congestionamento), especificação do modelo, nível de agregação, medida de transporte, modal de transporte, país e período analisado, setor específico e o período de tempo avaliado.

Para melhor contextualizar o objeto de estudo deste trabalho, este capítulo está dividido em quatro seções. Inicialmente são tratados os principais aspectos teóricos desenvolvidos pela ciência econômica que caracterizam o setor de infraestrutura. Neste momento, aborda-se o tema dos monopólios naturais e a necessidade da regulação de mercado. Em seguida, apresentam-se trabalhos que tenham avaliado especificamente o impacto do setor de transportes na economia, com foco no desenvolvimento da Nova Geografia Econômica. Na terceira parte, aponta-se a evolução da infraestrutura no Brasil, destacando seus gargalos e trazendo um breve histórico do financiamento no setor de transportes. Além disso, dado o interesse em aspectos contratuais da infraestrutura, são expostos os principais modelos de 
contratação atualmente permitidos aos gestores públicos do Brasil, destacando algumas de suas vantagens e desvantagens. Por fim, são apresentados trabalhos que têm discutido as diferentes alternativas contratuais para a contratação e financiamento de projetos de infraestrutura.

\subsection{Aspectos teóricos do setor de infraestrutura}

O setor de infraestrutura apresenta um vasto campo de exploração das teorias econômicas, porém, antes de se aprofundar no debate sobre os aspectos teóricos que permeiam esse setor, é importante definir apropriadamente o que é infraestrutura. Tentando definir o investimento na infraestrutura, Grimsey e Lewis (2004) apontam que distintas definições ressaltam o potencial desse investimento de prover serviços básicos para a indústria, para as famílias e a sua importância para a atividade e o crescimento econômico. Tecendo uma definição mais elaborada, Argy et al. (1999, apud GRIMSEY e LEWIS, 2004) distinguem duas classificações para a infraestrutura, a saber, a infraestrutura pode ser econômica ou social, e pode ser, também, hard ou soft. A infraestrutura econômica é aquela que provê serviços intermediários essenciais para o desenvolvimento da produtividade e eficiências para os negócios e indústrias do país, enquanto a social volta-se mais para a provisão de serviços básicos para as famílias, focando na melhoria da qualidade de vida e do bem estar das comunidades. Já infraestrutura chamada de hard é aquela que envolve a construção física de ativos ou equipamentos públicos, enquanto a soft" está mais ligada à gestão ou questões institucionais. A Tabela 1 a seguir classifica alguns tipos de infraestrutura conforme essa classificação. 
Tabela 1 - Classificação da infraestrutura

\begin{tabular}{lll}
\cline { 2 - 3 } & "Hard” & "Soft” \\
\hline Econômica & $\bullet$ Rodovias & $\bullet$ Treinamento vocacional \\
& $\bullet$ Estradas & $\bullet$ Instituição financeira \\
& $\bullet$ Pontes & $\bullet$ Institutos de P\&D \\
& $\bullet$ Portos & $\bullet$ Transferência de tecnologia \\
& $\bullet$ Aeroportos & \\
& $\bullet$ Telecomunicação & \\
& $\bullet$ Energia & \\
\hline Social & $\bullet$ Hospitais & $\bullet$ Seguridade social de exportação \\
& $\bullet$ Escolas & $\bullet$ Agências ambientais \\
& $\bullet$ Suprimento de água & \\
& $\bullet$ Habitação & \\
& $\bullet$ Esgotamento sanitário & \\
& $\bullet$ Creches & \\
& $\bullet$ Prisões & \\
& $\bullet$ Asilo & \\
\hline
\end{tabular}

Fonte: Grimsey e Lewis (2004)

É importante ressaltar que esta classificação é apenas um indicativo do impacto e das características de cada infraestrutura, porém, na prática, essas diferenças são mais difusas. Pode-se argumentar, por exemplo, que a educação, escolas ou esgotamento também impactam a produtividade das firmas, o que, segundo a definição apresentada, as classificariam como infraestrutura econômica e não social. Dentro dessa definição apresentada, o presente trabalho avalia principalmente a infraestrutura econômica do tipo "hard", porém, as diversas questões que serão analisadas ao longo desse estudo, surgem, em maior ou menor intensidade, também nos outros tipos de infraestrutura.

As seções a seguir apresentam alguns aspectos teóricos relacionados à infraestrutura. Inicialmente descrevem-se algumas falhas de mercado presentes no setor, em seguida abordase o tema de monopólios naturais e, por fim, discute-se o papel dos contratos para projetos de infraestrutura e a questão de seus incentivos. 


\subsubsection{Falhas de mercado}

As falhas de mercado descrevem algumas das situações em que as forças naturais dos mercados não são capazes de alocar os recursos da maneira mais eficiente. As externalidades e assimetrias de informação são duas falhas de mercado muito presentes no setor de infraestrutura e na estruturação de seus contratos, de forma que essas situações merecem uma análise mais aprofundada, que será elaborada ao longo desta seção.

É dito que um mercado possui externalidades quando eventos internos a ele afetam indiretamente outros mercados a sua volta. A externalidade pode ser negativa, por exemplo, uma fábrica que polui um rio pode diminuir a disponibilidade de peixes que sustentam um pescador rio abaixo, ou pode ser positiva, como uma nova estação de metrô que atrai novas oportunidades de negócios para determinada região aumentando o preço dos aluguéis (NICHOLSON e SNYDER, 2005).

$\mathrm{Na}$ presença de externalidades os preços do mercado não mais refletirão os custos sociais, mas sim os custos individuais da firma produtora. Nessa situação, o retorno privado do investimento irá diferir do seu retorno social. As externalidades podem levar os mercados a uma alocação ineficiente dos recursos, pois cada firma maximiza seu próprio lucro desconsiderando os impactos indiretos de suas ações nos demais agentes da economia.

Outra falha de mercado típica do setor de infraestrutura é a assimetria de informações entre as partes envolvidas em contratos. Nesta situação, uma das partes possui informações privadas não compartilhadas com a outra e a alocação de mercado não mais será eficiente. O principal modelo para estudar as assimetrias de informação é o modelo de agente-principal, onde duas partes interagem para firmar um contrato: (i) o principal é aquele que está contratando, no caso do setor de infraestrutura, o principal é, em geral, o setor público que deseja construir uma nova obra estruturante; e (ii) o agente é aquele que está sendo contratado para executar o serviço, ou seja, a empreiteira ou grupo privado que deverá executar a obra ou operar o projeto sendo contratado. Neste modelo, o agente é quem possui informações privadas não compartilhadas com o principal (NICHOLSON e SNYDER, 2005).

As duas assimetrias de informação mais estudadas são a seleção adversa e o risco moral. No primeiro caso, a informação privada retida pelo agente refere-se a suas características intrínsecas como sua produtividade, eficiência ou preferências (a característica vai depender 
do problema em análise). Na infraestrutura pode-se observar a seleção adversa quando o setor público está selecionando uma empresa para executar e/ou operar algum projeto. Neste caso, o setor público (principal) desconhece a produtividade, a estrutura de custos, a qualidade dos projetos e a eficiência das empresas proponentes, porém deve propor, no momento da licitação, um contrato comum para todas elas. No risco moral, o principal pode observar um resultado correlacionado com as ações do agente, porém a ação em si trata-se de uma ação oculta do agente, a qual o principal não tem informações. Assim, ao contratar uma empresa para construir determinada obra, o principal sabe que a qualidade da obra está relacionada ao esforço da empreiteira, porém, ele não é capaz de observar esse esforço, podendo observar apenas a qualidade final da obra.

\subsubsection{Monopólio natural e regulação}

Um monopólio é caracterizado pela situação em que uma única firma atende sozinha a todo um mercado (NICHOLSON e SNYDER, 2005). Segundo Brauetingam (1989), a explicação tradicional para a existência dos monopólios naturais sustenta-se na existência de retornos crescentes de escala em determinadas indústrias. Nesta situação, o custo médio de se produzir uma unidade do produto diminui à medida que a quantidade produzida aumenta. Assim, torna-se mais eficiente que uma única firma atenda a todo mercado do que diversas firmas competindo por ele, pois, a firma monopolista seria capaz de atingir o menor custo médio de produção. Uma abordagem mais recente para explicar a existência de monopólios naturais baseia-se na existência de custos subaditivos para firmas produzindo mais de uma mercadoria (BRAUETINGAM, 1989). Esse conceito caracteriza-se pela situação em que uma única firma é capaz de produzir um vetor de produtos a um preço mais baixo do que diversas firmas produzindo conjuntamente o mesmo vetor. Esse conceito é mais abrangente que a explicação tradicional do monopólio, porém, quando as firmas analisadas produzem um único produto, os dois conceitos convergem para a mesma coisa, qual seja, o ganho de escala faz com que uma firma produza para todo o mercado de forma mais eficiente que diversas firmas.

As firmas monopolistas, por atenderem a todo o mercado, enfrentam uma curva de demanda decrescente no preço. Ao buscarem maximizar seu lucro, essas firmas irão igualar seu custo marginal de produção não à demanda, mas à sua própria receita marginal. Nesta situação o 
preço cobrado é no mínimo igual ao custo médio de produção, de forma que a firma poderá auferir um lucro acima de zero (NICHOLSON e SNYDER, 2005).

Para se tratar de questões de regulação de mercados monopolistas é importante discutir a questão da alocação ótima do mercado, o que é feito por meio do exemplo discutido a seguir. ${ }^{3}$ Supondo que a estrutura de custos de uma determinada firma seja composta por um custo fixo positivo $F$ e um custo variável $m$, de forma que, o custo para produzir uma quantidade $y$ é:

$$
\mathrm{C}(\mathrm{y})=\mathrm{F}+\mathrm{my}
$$

Como pode ser observado na Figura 1, o custo marginal de produzir y é constante na quantidade produzida, porém, o custo médio será decrescente.

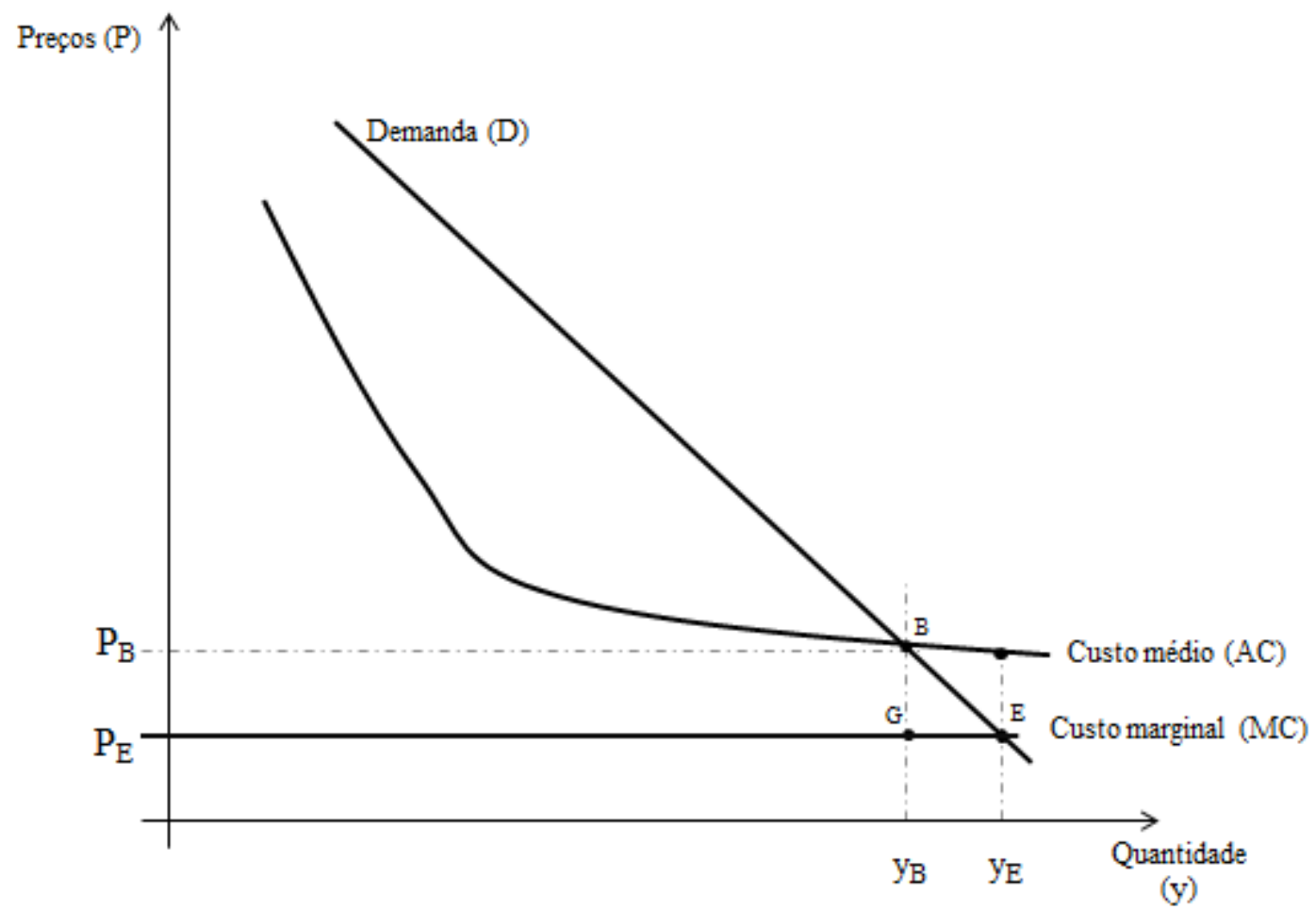

Figura 1- Mercado com ganhos de escala

Fonte: Elaboração própria baseado em Brauetingam (1989)

\footnotetext{
${ }^{3}$ Exemplo tirado de Brauetingam (1989).
} 
De acordo com Brauetingam (1989), o benefício econômico líquido é maximizado quando a quantidade produzida iguala o custo marginal de produção com a demanda (ponto E). Nesse ponto, todo consumidor que estiver disposto a pagar pelo menos o custo marginal de produção poderá consumir o produto. Por maximizar os benefícios líquidos, essa situação é conhecida como first-best, porém, na presença de um custo fixo, essa não é uma alocação factível, uma vez que a firma estaria incorrendo em prejuízo por vender a um preço $\left(\mathrm{P}_{\mathrm{E}}\right)$ mais baixo que seu custo médio de produção (curva AC).

Devido ao custo fixo $\mathrm{F}$, o ponto que iguala preço ao custo marginal (ponto E) trará prejuízos para a firma. Dessa forma, o ponto conhecido como second-best será aquele que maximiza o benefício social líquido, permitindo que a firma produtora não tenha prejuízo. Nessa situação, o preço de mercado se igualará ao custo médio de produção (ponto B). A situação de secondbest traz uma perda líquida de bem estar para a sociedade em relação à situação ótima (firstbest), o que, nesta figura é representado pela área do triangulo BGE (BRAUETINGAM, 1989). Brauetingam (1989) discute que, nos monopólios naturais, sem a intervenção do governo não é possível que o mercado atinja a situação de first-best, porém, em determinados casos se pode atingir uma eficiência econômica próxima ao second-best, como se verá adiante.

Demsetz (1968) sugere que mercados caracterizados pelos monopólios naturais deveriam ser atendidos por uma única firma que conquiste o direito de fornecimento por meio de um leilão de menor preço. Nessa situação as firmas estariam competindo pelo direito de fornecer para o mercado, em oposição à competição dentro do mercado. Demsetz aponta que em monopólios naturais, a competição pelo mercado leva a um equilíbrio próximo ao second-best caso duas hipóteses sejam atendidas, a saber: (i) insumos para a produção no mercado em questão devem estar disponíveis para todos os participantes do leilão; e (ii) o custo de cartelização deve ser muito elevado para todos os participantes.

Demsetz (1968) ainda aponta outra vantagem nos mecanismos de competição pelo mercado por meio de leilões pelo menor preço. Em um contexto de assimetria de informação, um leilão com muitas firmas competindo gera incentivos para que as firmas revelem seus respectivos custos médios de produção e a firma vencedora será aquela mais eficiente, pois será capaz de oferecer o menor custo. Como uma única firma atenderá a todo o mercado, uma firma que 
proponha um valor acima de seu custo médio de produção pode perder a disputa para outra firma disposta a cobrar menos pelos serviços.

Williamsom (1976) critica o modelo sugerido por Demsetz, alegando que nos contratos de longo prazo o poder público seria incapaz de se comprometer ex-ante com o menor preço proposto pela firma vencedora do leilão, o que gera incentivos perversos para as firmas em disputa. Uma empresa com mais habilidade política poderia sugerir um preço unitário menor do que seu custo médio apostando em uma renegociação favorável após vencer o certame. Os altos custos de realizar um novo leilão e o elevado custo irrecuperável do investimento em obras estruturantes diminuem a capacidade do poder público de se comprometer com os preços vencedores do leilão tornando-o menos avesso a renegociações futuras.

Estudando estes efeitos, Guasch (2004) avalia a renegociação dos contratos de concessão. Neste estudo, foram analisados mil contratos de concessão nos setores de transporte, energia, telecomunicações e saneamento para países da América Latina e do Caribe entre meados dos anos 1980 e $2000 .{ }^{4} \mathrm{O}$ autor encontra que $30 \%$ das concessões tiveram significativas alterações contratuais. No setor de transportes e saneamento, o problema é mais grave, com renegociações acontecendo em 55\% e 74\% dos casos, respectivamente. Além disso, analisando o tempo transcorrido entre a assinatura do contrato e sua renegociação, o autor encontra que no setor de transporte, a renegociação demora em média 3,1 anos para acontecer, enquanto no saneamento levam em média 1,6 anos. Para os dados brasileiros, o autor encontra que nas concessões de transportes, $56 \%$ dos contratos foram renegociados, enquanto no saneamento esse número sobe para $84 \%$.

Com base em fatos estilizados da teoria dos contratos, o autor estima um modelo probabilístico para avaliar os principais determinantes das renegociações. Entre as variáveis que impactam na ocorrência de reajustes contratuais destacam-se: choques macroeconômicos, critério de seleção baseado em menor tarifa, exigência de investimentos, nível de competição, aparato regulatório, ambiente político e o ciclo eleitoral.

Avaliando notificações e reajustes de 12 contratos de concessões rodoviárias do estado de São Paulo, Cardoso et al. (2012) concluem que as principais renegociações contratuais referem-se

\footnotetext{
${ }^{4}$ Os países avaliados são: Argentina, Bolívia, Brasil, Chile, Colômbia, Costa Rica, Equador, Guatemala, Jamaica, México, Panamá, Peru, Trinidad e Tobago, Uruguai e Venezuela
} 
ao cronograma de obras ou à expansão do escopo do contrato. Entre o período de 1999 e 2006 os autores analisam 144 termos de ajustes contratuais que haviam sido validados ou estavam sendo analisados. A maioria desses termos $(31 \%)$ pleiteava um reajuste no cronograma físicofinanceiro do projeto, $29 \%$ referiam-se a não aplicação na data prevista dos índices de reajuste tarifários e $21 \%$ referiam-se às alterações no escopo do projeto.

A competição pelo mercado, proposta por Demsetz (1968), extinguiria a necessidade de regulação dos serviços públicos, visto que a disputa entre proponentes levaria o mercado a tarifas próximas ao custo médio da firma mais eficiente. Contradizendo esta tese, Mougeot e Naegelen (2011) apontam que na teoria da regulação moderna esse mecanismo de seleção de firmas é visto como forma de aperfeiçoar o sistema regulatório e não como forma de substituí-lo. Os autores destacam três pontos para justificar a moderna regulação de setores com retornos crescentes: (i) não se pode especificar em contrato todas as dimensões de desempenho e qualidade dos serviços prestados; (ii) contratos devem acomodar incertezas que podem surgir ao longo de sua duração, que pode ser o não cumprimento de alguma cláusula por parte da firma ou o comportamento oportunista da incumbente após conquistar o direito de servir o mercado; e (iii) produtores potenciais podem ficar relutantes em incorrer em custos de investimento caso acreditem que esses valores não serão recuperados (por exemplo, caso o custo de elaborar uma proposta seja muito elevado, muitas firmas serão desencorajadas a participar do certame).

Duas formas são usualmente utilizadas para regular a prestação de serviços públicos com carácter monopolistas, a saber, a regulação por taxa de retorno e por preço teto. No primeiro caso, a agência reguladora fixa uma taxa de retorno para o setor e a tarifa é ajustada de forma a manter fixo esse retorno sobre o capital. Já na regulação por preço teto, o regulador ajusta o preço cobrado pelo serviço a cada ano por meio de um índice de preços (acrescido, ou não, por um fator pré-determinado relativo à eficiência). Na regulação por preço teto, a firma regulada tem maiores incentivos para diminuir seus custos, uma vez que ela poderá reter o excedente de preços, o que não acontece na regulação por taxa de retorno, onde o regulador reajusta a tarifa para compensar variações nos custos (ALEXANDER e IRWIN, 1997).

Sob a regulação por taxa de retorno, o risco suportado pela empresa regulada é consideravelmente menor do que o risco suportado pela regulada por preço teto, isso porque, no primeiro caso, o retorno do capital está garantido, enquanto no segundo não. O menor risco 
suportado sob a regulação por taxa de retorno reflete-se em um menor custo de capital da firma regulada, que impacta diretamente no custo total do empreendimento (ALEXANDER e IRWIN, 1997). Em seu estudo sobre concessões na América Latina e Caribe, Guasch (2004) encontrou que nos casos regulados por meio de um preço teto, as renegociações contratuais, em particular aquelas induzidas pela concessionária, são mais comuns do que nos casos de regulação por taxa de retorno.

\subsubsection{Contratos de infraestrutura}

Teoria dos contratos geralmente refere-se à teoria dos incentivos, informações e a instituições econômicas (BOLTON e DEWATRIPONT, 2005). Agentes com diferentes objetivos e motivações assinam contratos para benefício mútuo e buscam extrair a maior utilidade possível do acordo firmado. No início do século passado, a teoria econômica preocupava-se, primordialmente, com a alocação eficiente de recursos entre agentes da economia sem considerar cenários de incerteza e assimetrias de informação.

Com trabalho de von Neumann e Morgenstern (1944 apud BOLTON e DEWATRIPONT, 2005), surge a ideia de escolha sob incerteza, em que agentes fazem escolhas com base na expectativa de utilidade auferida. Bolton e Dewatripont (2005) apontam que transações mais complexas passaram a ser avaliadas com a introdução da ideia de estados contingentes elaboradas por Arrow (1964, apud BOLTON e DEWATRIPONT, 2005) e Debreu (1959 apud BOLTON e DEWATRIPONT, 2005). Intuitivamente, a ideia de estados contingentes está atrelada a um evento que irá trazer resultados desconhecidos para o ambiente de contratação. Os agentes não sabem ao certo qual evento ocorrerá e nem qual o estado do ambiente decorrente de tal evento, porém, podem classificar as diversas possibilidades de resultados em estados contingentes. Ao firmarem um contrato ex-ante a ocorrência do evento, os agentes combinam quais os respectivos deveres e obrigações para cada um dos possíveis estados. Uma vez que o evento ocorreu e seu resultado é conhecido, passam a valer as cláusulas negociadas para aquela situação. Por vezes, os custos de mapear e avaliar todos os possíveis cenários resultantes de um evento tornam-se muito altos, impossibilitando a criação de contratos contingentes para todas as possibilidades. Nestas situações diz-se que os contratos 
são incompletos e muitas decisões sobre o contrato devem ser tomadas já em um estágio avançado das negociações.

A partir dos anos 60, surge o conceito de assimetrias de informações e os contratos passam a avaliar incentivos para mitigar os problemas de informação privada e ação oculta. Restrições de incentivo e de participação passam a fazer parte dos desenhos contratuais para as situações de risco moral e seleção adversa. Neste cenário, parte da remuneração do agente sendo contratado está atrelada aos resultados observados pelo principal. Nos anos 80 e 90, contratos dinâmicos e de longa duração passam a ser avaliados, trazendo para a discussão problemas associados ao comprometimento do principal com o contrato negociado ex-ante e à renegociação contratual ex-post. Avanços mais recentes na teoria dos contratos também avaliam contratos incompletos de longo prazo, analisando o impacto da distribuição acionária e de propriedade entre os participantes do certame (BOLTON e DEWATRIPONT, 2005).

Apesar de a teoria dos contratos ter avançado bastante principalmente a partir do século $\mathrm{XX}, \mathrm{o}$ conceito de parceria entre o setor púbico e privado para a execução de projetos e obras de infraestrutura é bastante antigo. Na França, a primeira concessão data do século XVII e refere-se à construção e ao financiamento do Canal Briare, e também, grande parte da rede de trilhos, instalações para o fornecimento de água e iluminação de ruas do país foram desenvolvidos sob alguma forma de Parcerias Público-Privada (RIBAULT, 2001 apud GRIMSEY e LEWIS 2004). Ao longo dos anos, diversos modelos foram sendo usados e testados por diferentes governos para tentar suprir suas necessidades de capital e de expertise em setores específicos. As formas de atração do capital privado para investimentos em infraestrutura são diferenciadas pelo nível dos riscos, deveres e obrigações que ficam sob responsabilidade do parceiro privado.

Em um extremo da distribuição de responsabilidades está a privatização completa de determinado serviço. Nesta situação, o setor privado torna-se proprietário dos ativos necessários à prestação dos serviços, cabendo a ele gerenciar todos os riscos envolvidos na operação. No outro extremo da distribuição, existe o fornecimento público dos serviços, onde o estado torna-se responsável pelos investimentos, operação e manutenção de todas as etapas do empreendimento. Entre os extremos dessa distribuição, existem diversos modelos 
institucionais pelos quais o setor público e o setor privado podem interagir para a provisão de serviços públicos. ${ }^{5}$

É difícil acordar qual a exata definição de cada modelo de contratação, pois nuances podem surgir para se adaptar às regras e realidades de cada país, região, contexto político e econômico, etc. De forma geral, essas modalidades diferem entre si no que diz respeito às responsabilidades pelo projeto, construção, financiamento, operação, gestão, manutenção da infraestrutura e mesmo a propriedade dos ativos.

Pela classificação usual da literatura internacional Parceria Público-Privada (PPP) caracteriza uma série de arranjos institucionais entre o setor público e o privado para a provisão de serviços públicos. No entanto, no restante deste trabalho, o termo PPP será usado em seu sentido mais restrito, ou seja, aquele que designa uma modalidade específica de contratação brasileira com regras bastante claras e definidas em Lei Federal (Lei n $\left.{ }^{\circ} 11.079 / 2004\right)$ e com regramentos estaduais e municipais. Porém, é importante salientar que diversos autores utilizam o termo Parceria Público-Privada em seu sentido mais amplo, remetendo às diversas formas de alinhar interesses entre o setor público e o privado em prol de um objetivo comum.

\subsection{A infraestrutura de transportes}

A questão da infraestrutura logística ganhou novo destaque com o advento da Nova Geografia Econômica (“NGE”), que, segundo Krugman (1998), introduziu novas estratégias de modelagem do problema locacional da atividade econômica. Segundo o autor, o efeito de aglomeração em cidades é fruto do equilíbrio entre duas forças opostas, a força centrípeta, que age no sentido de concentrar a atividade econômica, e a força centrífuga, que age no sentido contrário, dispersando a atividade. Puga (2002) ressalta que a grande contribuição da NGE é

\footnotetext{
${ }^{5}$ Grimsey e Lewis (2004) listam diversos modelos de interação entre setor público e privado em ordem crescente de responsabilidades do parceiro privado: (i) public provision of collective goods; (ii) service provision contracts; (iii) Outsourcing/contracting; (iv) Design and construct ( $D \& C$ ); (v) sale and leaseback; (vi) operate and maintain $(O \& M)$; (vii) Operate maintain and manage (OM \& M); (viii) Build Transfer Operate (BTO); (ix) Build Operate Transfer (BOT); (x) Build Lease Transfer (BLT); (xi) Build Lease Transfer Maintain (BLTM); (xii) Build Own Operate Remove (BOOR); (xiii) Build Own Operate Transfer (BOOT); (xiv) Lease Renovate Operate Transfer (LROT); (xv) Design Build Finance Operate (DBFO); (xvi) Design Construct Manage Finance (DCMF); (xvii) Design Build Finance Operate Manage (DBFOM); (xviii) Build Own Operate (BOO); (xix) Franchise; (xx) Concession; (xxi) Joint Venture (JV); (xxii) Regeneration partnership; e (xxiii) Outright privatization.
} 
justamente analisar o balanço entre essas duas forças por meio de uma estratégia comum de modelagem, permitindo avaliar a interação entre estes dois efeitos.

Duas estratégias de modelagem mostram-se primordiais para a existência de um equilíbrio locacional segundo a NGE, são elas, o custo de transporte entre distintas regiões e as economias de escala na produção (KRUGMAN, 1998; FUJITA e THISSE, 2002; OTTAVIANO, 2008). A economia de escala faz com que as firmas de grandes aglomerados urbanos sejam mais produtivas do que aquelas em relativo isolamento. Fujita e Thiesse (2002) destacam dois pontos da literatura, dentre vários existentes, que buscam explicar esse efeito da aglomeração na produtividade: a diversidade de bens intermediários para a produção e um matching facilitado no mercado de trabalho, ou seja, vagas são preenchidas por trabalhadores adequados com mais facilidade. Já o custo de transporte é essencial para que a dimensão espacial ganhe qualquer relevância na análise econômica. Variações nos custos de transporte entre distintas regiões podem fazer com que as firmas localizadas em aglomerados urbanos possam explorar, em maior ou menor intensidade, os efeitos de escala advindos da concentração da atividade econômica. Puga (2002) salienta que, se de um lado, a maior integração permite que regiões mais pobres tenham acesso a mercadorias produzidas nas regiões mais desenvolvidas, do outro lado, as firmas localizadas em regiões ricas, que usufruem de economia de escala devido à aglomeração, poderão ofertar seus produtos nas regiões mais pobres e distantes, o que pode prejudicar a industrialização dessa periferia.

Puga (1999) avalia que, na Europa, cerca de $25 \%$ da população mora em regiões cujo PIB per capita é inferior a 75\% da média da União Europeia, enquanto nos Estados Unidos apenas 2\% da população vive em regiões com PIB per capita é inferior a $75 \%$ da média americana. $\mathrm{O}$ autor destaca que, se por um lado a disparidade de renda entre as regiões americanas é inferior a essa disparidade entre as regiões da Europa, por outro, a produção dos Estados Unidos está mais concentrada em menores regiões. Partindo desse problema e pautando-se no arcabouço teórico da NGE, o autor busca entender a relação entre integração econômica (barreiras comerciais ou custos de transporte), migração de trabalhadores e a distribuição da atividade econômica.

O trabalho (PUGA, 1999) avalia que, na presença de ganhos de escala, pode surgir uma relação não monotônica entre integração econômica e aglomeração da produção. Quando os custos de transação são muito elevados (alto custo de transporte e baixa integração) a 
produção tende a ficar distribuída no espaço, de forma a se aproximar do consumidor final. Na medida em que o custo de transação cai, os ganhos de escala passam a atuar no sentido de concentrar a produção em aglomerados. Se os trabalhadores migram em busca dos maiores salários da região industrializada, a tendência de aglomeração se intensifica, eliminando o diferencial de salários entre as distintas regiões. Na ausência de migração, atenua-se o efeito de aglomeração, persistindo uma diferença de salários entre os trabalhadores de cada região. Nesse caso, uma queda ainda mais acentuada nos custos de transação leva a produção a se dispersar novamente em busca do custo mais baixo da força de trabalho. $\mathrm{O}$ autor argumenta que a diferença entre o grau de migração pode explicar as diferenças na concentração da produção e da renda entre Estados Unidos e Europa. Por essa lógica, nos EUA existe uma facilidade maior de migração o que diminui a diferença salarial entre as diferentes regiões e aumenta a concentração da produção devido às maiores possibilidades de explorar efeitos de escala devido à aglomeração.

Utilizando o arcabouço teórico da NGE, Gómez-Antonio e Fingleton (2002) buscam estimar a relação entre a produtividade e o estoque de infraestrutura em províncias espanholas no período de 1985 a 2004. Utilizando o nível de salários como proxy para o nível de produtividade, os autores concluem que, enquanto o estoque de infraestrutura tem impacto positivo na produtividade de uma região (o crescimento de $1 \%$ no estoque de infraestrutura aumenta em aproximadamente $0,08 \%$ a produtividade), um aumento no estoque de infraestrutura das regiões vizinhas tem impacto negativo na produtividade da região em análise, caracterizando um spillover negativo entre as províncias, tal resultado está alinhado com outros estudos da literatura (BOARNET, 1998). Os autores discutem que isso pode ser interpretado como o efeito de competição entre os vizinhos.

O efeito de spillover negativo da infraestrutura não é consenso na literatura. Avaliando diferentes trabalhos sobre o impacto da infraestrutura de transporte na economia, Berechman et al. (2006) estão interessados no fato de que, quanto mais se restringe a região de análise, menor se torna o impacto econômico observado da infraestrutura. Com dados de municípios, de distritos (counties) e de estados americanos entre os anos de 1990 e 2000, os autores avaliam uma função de produção aumentada pelo estoque de rodovias, tanto da própria região, quanto das regiões vizinhas. Ao observar que o impacto da infraestrutura na economia diminui à medida que se restringe a região de análise, os autores concluem que existem spillovers positivos entre regiões vizinhas. Isso implica que, por mais que os benefícios da 
infraestrutura pareçam pequenos para um município, eles podem ser relevantes para a região de forma agregada.

Também baseados na NGE, Roberts et al. (2010) elaboram um modelo inter-regional de equilíbrio geral para avaliar os impactos de curto prazo de um programa chinês que visa a construção de cerca de $41 \mathrm{mil} \mathrm{km}$ de rodovias, conectando todas as cidades com mais de 200 mil habitantes do país. Os autores trabalham com um modelo com dois setores (rural e urbano) e com 331 regiões distintas. Os custos de transporte são calculados por meio de dados georreferenciados das rodovias e regiões do país. Os autores encontram que o programa tem impacto positivo no produto agregado do país (incremento de aproximadamente $6 \%$ no PIB em 2007), porém, parece que a melhoria na rede de transportes não foi capaz de diminuir as disparidades regionais, nem a diferença de renda entre o setor urbano e rural, de forma que as regiões mais beneficiadas foram as que já eram mais produtivas. Conforme discussão do estudo, no longo prazo, tais disparidades regionais tendem a ceder devido à migração regional da população.

Nesta seção foram apresentados os efeitos esperados de uma redução nos custos de transportes à luz da NGE. A seguir, discutem-se questões práticas da estruturação de projetos de infraestrutura no Brasil, com especial foco para o transporte rodoviário, assim como um breve histórico do desenvolvimento desse setor no país.

\subsection{O setor de infraestrutura no Brasil}

Grandes obras de infraestrutura geram um relevante impacto econômico, ambiental e social no seu entorno. O Brasil é relativamente novo na construção desse tipo de obra em um ambiente democrático, uma vez que muitas das experiências com esses tipos de projetos vêm do período militar. Os baixos níveis de investimento em infraestrutura são claramente perceptíveis a partir do final do regime militar e da Constituição de 1988. Neste novo cenário, Souza et al. (2010) apontam que os gastos produtivos (saúde e saneamento, educação e cultura, habitação e urbanismo, comunicação, ciência e tecnologia, agricultura, indústria, 
comércio e serviços, energia e recursos minerais, transporte e defesa e segurança) ${ }^{6}$ do Governo Federal tiveram uma acentuada queda. O governo viu-se obrigado a expandir gastos improdutivos (assistência e previdência social, trabalho, direitos da cidadania, organização agrária, gestão ambiental e desporto e lazer ${ }^{7}$ que, numa situação de limitado orçamento, acabaram canibalizando recursos investidos anteriormente de maneira produtiva. Neste movimento, o investimento em infraestrutura foi particularmente prejudicado, conforme pode ser observado na Figura 2 abaixo.

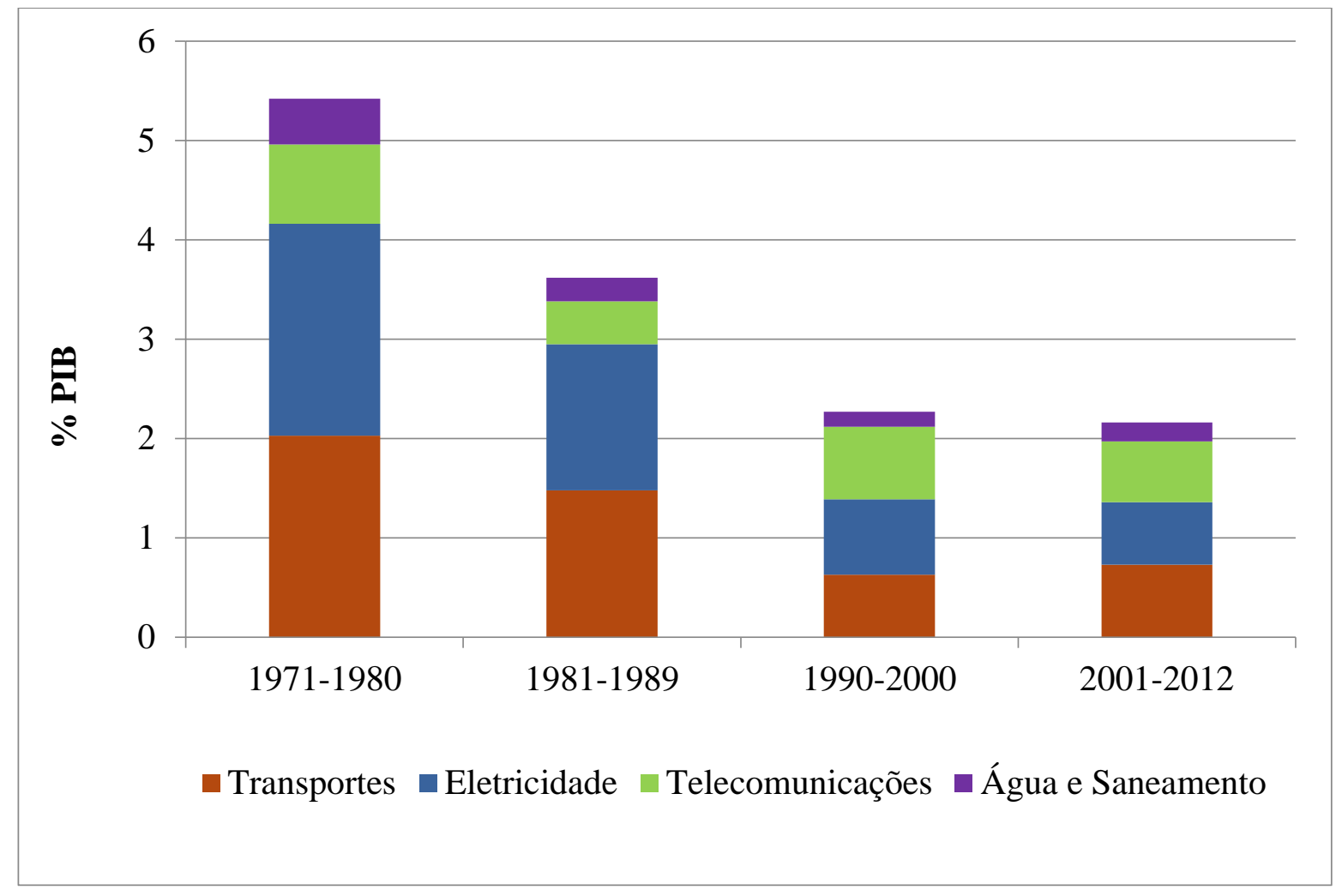

Figura 2 - Investimento por período e setor

Fonte: Frischtak e Davies (2014)

Nesta figura (Figura 2) de Frischtak e Davies (2014) é possível observar o alto patamar de investimentos em infraestrutura no período militar e sua queda a partir da década de 90, que se mantém mesmo após o fim dos desequilíbrios macroeconômicos dos anos 80 e início de 90. Em anos mais recentes, em particular a partir do lançamento do Programa para Aceleração

\footnotetext{
${ }^{6}$ Definição de acordo com Souza et al. (2010).

${ }^{7}$ Segundo definição de Souza et al. (2010).
} 
do Crescimento (PAC) do Governo Federal, observa-se uma leve reversão dessa tendência de baixos investimentos sendo liderada, principalmente, pelos recursos investidos no setor de transportes (Figura 3).

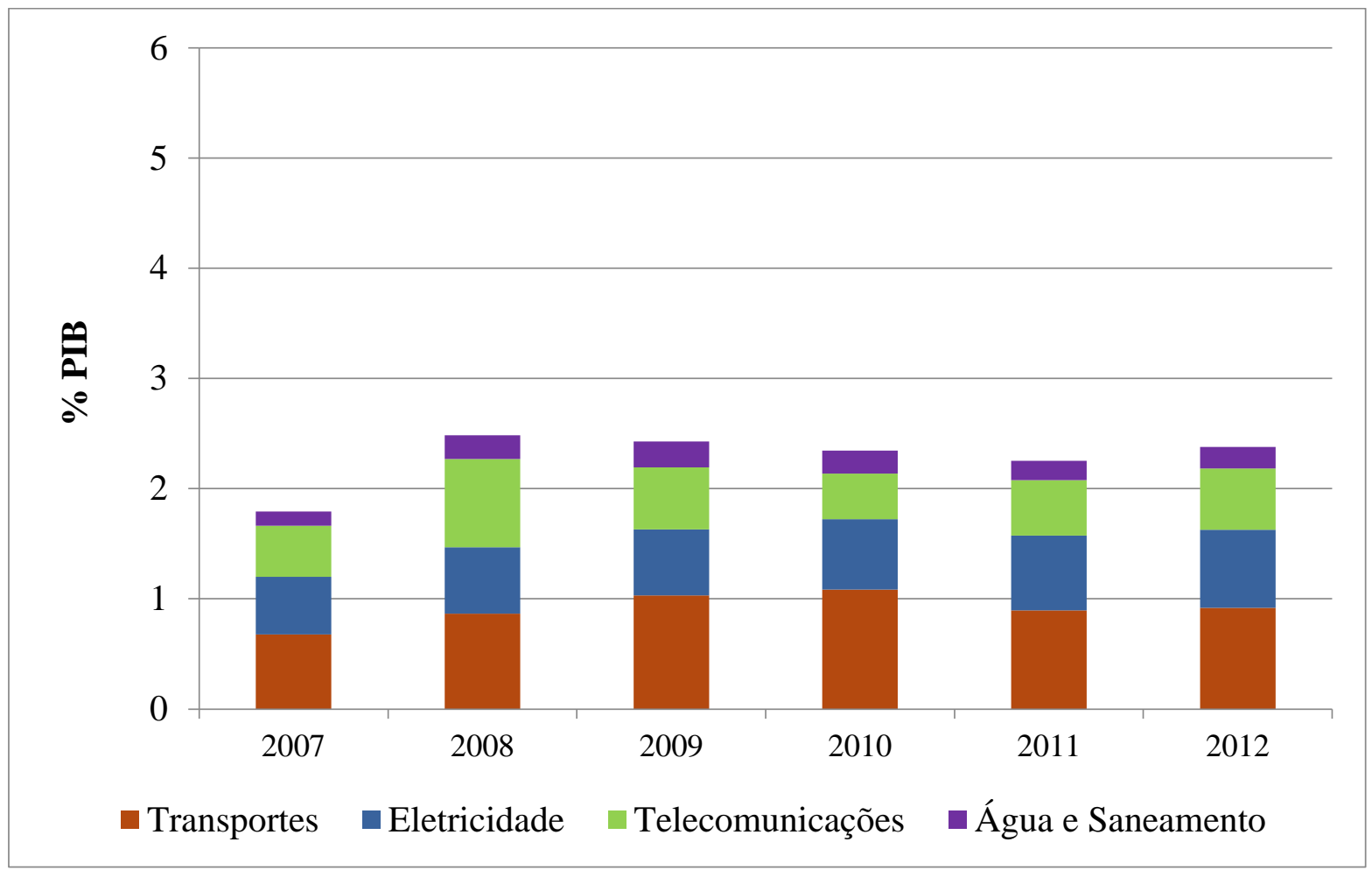

Figura 3 - Investimento recente anual por setor

Fonte: Frischtak e Davies (2014)

Para reverter o cenário de baixo investimento em projetos de infraestrutura e promover a eficiência setorial, o marco regulatório brasileiro tem evoluído no sentido de permitir uma interação cada vez maior entre o setor público e o privado para a execução de grandes obras, o que pode ser observado na evolução das modalidades contratuais permitidas no país que serão apresentadas a seguir.

\subsubsection{Empreitada comum}

Segundo Meirelles (2006), pelo contrato de empreitada "a administração compete ao empreiteiro a execução da obra, ou do serviço público, por sua conta e risco, mediante um preço fixo, ainda que reajustável”. Esses contratos são pautados na Lei Federal n o 8.666/1993, também conhecida como Lei de Licitações e Contratos Administrativos, que veio 
regulamentar o artigo 37 inciso XXI da Constituição Federal de $1988 .^{8}$ Além de determinar aspectos contratuais que devem ser atendidos pelas partes de um contrato público, esta lei define os procedimentos licitatórios, os quais são utilizados por diferentes regramentos contratuais, tais como a Lei das Concessões e a Lei das PPPs.

A Lei 8.666, em seu artigo 22, estabelece cinco modalidades licitatórias: concorrência, tomada de preços, convite, leilão e concurso. O artigo 23 da mesma lei determina que a concorrência deve ser obrigatoriamente a modalidade utilizada em serviços de engenharia ou de execução de obras acima de $\mathrm{R}$ \$ 1,5 milhão, ou para compra de materiais ou serviços acima R\$ 650 mil. Dessa forma, as grandes obras de que tratam o presente estudo são abarcadas pela modalidade concorrencial da licitação. $\mathrm{O}$ vencedor de um certame pode ser selecionado de acordo com: (i) menor preço; (ii) técnica e preço; (iii) melhor técnica; e (iv) maior lance ou oferta. Apesar dessas possibilidades, na prática, as grandes obras geralmente são contratadas pelo menor preço de proposta. Isso se deve à dificuldade do gestor público justificar, perante os órgãos de controle, o motivo de ter selecionado um empreendimento cuja proposta não foi a mais barata.

Na empreitada comum, o agente privado desliga-se do empreendimento tão logo este é entregue ao setor público, o que gera incentivos perversos para que o parceiro privado faça economias no curto prazo que não se refletem em economias no completo ciclo de vida do empreendimento. Essa economia pode se dar na escolha de materiais que se degradam rapidamente ou mesmo em projetos que não consideram o custo de operação e manutenção do objeto contratado.

É importante salientar que o artigo $7^{\circ}, \S 2^{\circ}$ inciso I da Lei no 8.666/93 determina que só se pode licitar obra mediante prévia disponibilidade de projeto básico aprovado pelas autoridades competentes, o que, na prática, implica na impossibilidade de contratação de projeto básico e construção sob o mesmo contrato. Apesar de inovadora por disciplinar as

\footnotetext{
8 “Art. 37. A administração pública direta e indireta de qualquer dos Poderes da União, dos Estados, do Distrito Federal e dos Municípios obedecerá aos princípios de legalidade, impessoalidade, moralidade, publicidade e eficiência e, também, ao seguinte:

XXI - ressalvados os casos especificados na legislação, as obras, serviços, compras e alienações serão contratados mediante processo de licitação pública que assegure igualdade de condições a todos os concorrentes, com cláusulas que estabeleçam obrigações de pagamento, mantidas as condições efetivas da proposta, nos termos da lei, o qual somente permitirá as exigências de qualificação técnica e econômica indispensáveis à garantia do cumprimento das obrigações" (BRASIL, 1988).
} 
compras e contratos públicos, Sá et al. (2013) apontam que a Lei 8.666/93 é muito criticada desde a sua criação por seu excesso de formalismo e burocracia, contando com poucos elementos que induzam a eficiência dos contratos.

Buscando atender ao princípio da eficiência, que norteia o artigo 37 da Constituição Federal, novas modalidades de contratação passaram a ser incluídas na legislação brasileira. ${ }^{9}$ Os novos regramentos buscam incentivar a eficiência do parceiro privado por meio de um alinhamento de objetivos com o Poder Concedente. Nesse sentido surgiram as Leis das Concessões, das Parcerias Público-Privadas e, mais recentemente, o Regime Diferenciado de Contratação, que serão apresentados em seguida.

\subsubsection{Concessão}

Para atualizar as contratações públicas e suprir uma demanda por recursos para investimentos, em 28 de setembro de 1995 o Governo Federal editou a Lei das Concessões (Lei Federal $n^{\circ}$ 8.987/95). Essa lei veio regulamentar o artigo 175 da Constituição Federal que "incumbe ao Poder Público, na forma da lei, diretamente ou sob regime de concessão ou permissão, sempre por meio de licitação, a prestação de serviços públicos”.

Conforme comentado, a modalidade licitatória para seleção de concessionárias é a concorrência regrada pela Lei das Licitações, mas os critérios de julgamento da Lei das Concessões tiveram redação dada pela Lei $n^{0}$ 9.648/1998 que prevê sete alternativas: (i) menor valor da tarifa do serviço público a ser prestado; (ii) maior oferta, nos casos de pagamento ao poder concedente pela outorga da concessão; (iii) a combinação, dois a dois, dos critérios i, ii e vii; (iv) melhor proposta técnica, com preço fixado no edital; (v) melhor proposta em razão da combinação dos critérios de menor valor da tarifa do serviço público a ser prestado com o de melhor técnica; (vi) melhor proposta em razão da combinação dos critérios de maior oferta pela outorga da concessão com o de melhor técnica; ou (vii) melhor oferta de pagamento pela outorga após qualificação de propostas técnicas. Importante destacar

\footnotetext{
${ }^{9}$ O princípio da eficiência passou a nortear explicitamente o artigo 37 da Constituição em junho de 1998 através de Emenda Constitucional $n^{\circ} 19$.
} 
a titularidade do núcleo dos serviços permanece com o poder público e é apenas delegada por prazo determinado ao parceiro privado (JUSTEN FILHO, 2003).

Os contratos sob a Lei $n^{0} 8.987 / 95$ são chamados de Concessão Comum, pois, a partir de 2004 a Lei das PPPs (que será apresentada a seguir) trouxe ao regramento brasileiro dois novos tipos de concessão, a administrativa e patrocinada. A Lei das Concessões permite contratos de longo prazo, o que possibilita alinhar os interesses do setor público e do privado por uma economia de custos ao longo do ciclo de vida do projeto, e não apenas no curto prazo como ocorria sob a empreitada comum. Após a edição dessa lei, diversos serviços foram concedidos para a exploração do setor privado, e, em particular no setor de infraestrutura rodoviária. Porém, diversos empreendimentos passíveis de serem administrados eficientemente pelo setor privado não se sustentavam como concessão comum, pois a tarifa não era suficiente para remunerar o investimento e o custo de capital do setor privado. Assim, novos modelos começaram a ser propostos, culminando na edição da Lei das PPPs.

\subsubsection{Parceria Público-Privada}

A Lei Federal $n^{0} 11.079$ de 30 de dezembro de 2004 veio estabelecer as regras para as Parecerias Público-Privadas no Brasil (sentido restrito do termo Parceria Público-Privada PPP). Esta evolução da Lei das Concessões era uma demanda setorial para viabilizar projetos em mercados onde a simples cobrança de tarifa dos usuários não era suficiente para cobrir os custos de operação, investimento e o custo de capital do setor privado. A complementação tarifária por parte do Estado surge na forma de uma contraprestação pecuniária paga periodicamente ao parceiro privado conforme condições firmadas em contrato. A Lei das PPPs normatiza dois distintos tipos de concessão: (i) Concessão Patrocinada, na qual uma tarifa do usuário é complementada por contraprestação do Poder Concedente; e (ii) Concessão Administrativa, em que toda a remuneração do parceiro privado provêm das contraprestações do Poder Concedente. Os procedimentos licitatórios na modalidade concorrencial são utilizados pelas PPPs e a seleção de proposta segue as mesmas regras das concessões comuns (aquelas definidas pela Lei $\mathrm{n}^{\mathrm{o}} 8.987 / 95$ ), acrescidas do julgamento de proposta com base na 
menor contraprestação. A Lei das PPPs permite também a inversão de fases no certame ${ }^{10}$, onde primeiramente julga-se a proposta apresentada e, em seguida, avalia-se a habilitação do proponente. Segundo Pinto e Rosilho (2008) a inversão de fases pode: (i) reduzir a duração do processo licitatório; (ii) economizar recursos da administração pública; (iii) diminuir a ocorrência de disputas judiciais; e (iv) evitar que licitantes capacitados deixem de ser avaliados por meros enganos de documentação.

A Lei das PPPs prevê que os contratos de concessão nas modalidades patrocinada ou administrativa são vedados para projetos cujo valor seja inferior a $\mathrm{R} \$ 20$ milhões de reais, cujo período de prestação dos serviços seja inferior a cinco e superior a trinta e cinco anos, ou ainda, para os projetos que tenham como objetivo único o fornecimento de mão-de-obra, fornecimento e instalação de equipamentos, ou a simples execução de obras públicas. O seu longo prazo de duração é compatível com a execução de investimentos iniciais, visto que permite a amortização do valor investido ao longo do tempo.

O parceiro privado que almeja firmar parceria com o Poder Concedente por meio da Lei das PPPs deve fazê-lo mediante a criação de uma Sociedade de Propósito Específico (SPE), entidade jurídica formada por empresa ou consórcio de empresas que tem como única finalidade a execução de um objeto sendo contratada pelo Estado.

Em 2012, a Lei Federal n ${ }^{\circ} 12.766$ traz uma evolução para a Lei das PPPs, apresentando a figura do aporte de recursos em favor do parceiro privado. Se de um lado o aporte representa um alívio físcal à SPE, que deixa de se responsabilizar pelo financiamento dos investimentos iniciais, do outro, esse valor desonera a contraprestação futura devida à SPE do custo de capital cobrado pelo parceiro privado, uma vez que tal custo está embutido na contraprestação. Mesmo que o Estado tenha que se financiar para pagar o aporte, essa estratégia ainda pode ser vantajosa, uma vez que o custo de captação do Estado é geralmente inferior ao da SPE.

\footnotetext{
10 A inversão de fases passou a ser permitida também nas concessões comuns a partir da Lei Federal $\mathrm{n}^{\circ}$ $11.196 / 1995$.
} 


\subsubsection{Regime Diferenciado de Contratação}

O Regime Diferenciado de Contratação (RDC) surgiu em 4 de agosto de 2011 com a sanção da Lei $n^{0}$ 12.462. Essa nova modalidade de contratação trouxe diversas inovações aos regramentos contratuais do Brasil permitindo que, através de um mesmo contrato denominado de empreitada integral (Art. $2^{\circ}$, inciso I), um parceiro privado seja selecionado para projetar e construir determinada obra. Essa lei surgiu com aplicações restritas a eventos desportivos que seriam sediados pelo país, a saber, Copa das Confederações, Copa do Mundo, Olimpíadas e Paraolimpíadas e almejava dar celeridade ao processo de contratação das obras.

Essa nova legislação prevê duas alternativas para remunerar o contratado: (i) uma remuneração variável vinculada ao desempenho do contratado prevista no artigo 10 onde, segundo Schwind (2012), o contratado percebe maior remuneração na medida em que logra atingir metas de qualidade pré-estabelecidos; e (ii) nos chamados contratos de eficiência, contemplado pelo artigo 23 da Lei do RDC, a remuneração do parceiro privado é uma proporção das economias que ele gera ao administrador público. Percebe-se que ambos os contratos buscam alinhar os interesses do setor privado aos do poder concedente, porém, como contrapartida, trazem um maior risco ao parceiro privado. Outro fator que traz riscos ao parceiro privado é que na contratação integrada é vedada a celebração de termos de aditamento contratual, exceto nos casos de recomposição do equilíbrio econômico-financeiro e da necessidade de alterações de projeto.

A contratação integrada, por concentrar projeto e obra sob um mesmo contrato, confere celeridade à contratação e, por esse motivo foi desenhada pensando-se especificamente nos eventos desportivos sediados pelo Brasil. Segundo o artigo $1^{\circ}$ da Lei do RDC, essa contratação é vedada para objetos outros que não: (i) obras dos Jogos Olímpicos e Paraolímpicos 2016; (ii) Copa das Confederações e Copa do Mundo; (iii) obras para aeroportos distantes em até $350 \mathrm{~km}$ de alguma cidade sede da Copa do Mundo; (iv) ações integradas do Programa de Aceleração do Crescimento (PAC); (v) obras no âmbito do SUS; e (vi) obras e serviços relativos à construção, ampliação e reforma prisional. O RDC ainda é um modelo de contrato muito recente e pouco explorado no país, de forma que ainda não se tem uma clara conclusão acerca de sua efetividade. 


\subsubsection{A infraestrutura rodoviária no Brasil}

O Brasil é um país que possui sua capacidade logística extremamente concentrada no modal rodoviário. Segundo dados do Ministério dos Transportes (BRASIL, 2012c) cerca de 52\% de toda a produção brasileira é escoada pelo modal rodoviário, enquanto nas ferrovias escoam apenas 30\%. Apesar da alta concentração de frete no modal rodoviário, o Brasil ainda apresenta uma baixa densidade de rodovias. ${ }^{11}$ Pesquisa da CNT (2014) aponta que o país possui $23,9 \mathrm{~km}$ de rodovia para cada $1.000 \mathrm{~km}^{2}$ enquanto na Rússia esse valor é de $54,3 \mathrm{~km}$, na China é 359,9 km e nos EUA 438,1 km. A infraestrutura logística brasileira, e sua alta dependência ao modal rodoviário, foi classificada em $65^{\circ}$ lugar de um total de 160 países de acordo com o Índice de Performance Logística calculado pelo Banco Mundial (ARVIS et al. 2014).

Essa dependência do modal rodoviário passou a ser instituída no Brasil a partir do governo de Juscelino Kubitscheck que, com seu Plano de Metas, passou a priorizar os investimentos em transporte rodoviário em detrimento de outros modais. Em 1950, as rodovias representavam apenas $38 \%$ do transporte de cargas no Brasil. Tal valor foi significativamente alterado no decorrer do desenvolvimento da infraestrutura do país (CAMPOS NETO et al., 2011). Grande parte da malha rodoviária construída na segunda metade do século XX foi financiada por meio de recursos direcionados especificamente para este propósito. Em 1945, criou-se o Fundo Rodoviário Nacional (FRN), com o objetivo de fomentar a implementação do Plano Rodoviário Nacional. As receitas do FRN provinham inicialmente de um imposto sobre combustíveis e lubrificantes (IUCLLG - Imposto Único sobre Combustíveis e Lubrificantes Líquidos e Gasosos), ao qual se somou um imposto sobre os serviços rodoviários de transporte de cargas e passageiros. A partir de 1974, o IUCLLG foi paulatinamente sendo transferido para o Fundo Nacional de Desenvolvimento (FND) até que, em 1982, extinguiu-se por completo a vinculação destes impostos ao setor rodoviário (LACERDA, 2005; FERREIRA, 2009).

\footnotetext{
11 Segundo dados do Sistema Nacional de Viação (SNV) em 2014 a extensão da malha rodoviária era de cerca de 1,7 milhões de quilômetros, sendo que apenas 12\% (203 mil km) eram pavimentados. Da malha pavimentada, apenas 66 mil km pertenciam ao Governo Federal sendo que as rodovias de pistas simples representam a grande maioria.
} 
O imposto sobre combustíveis e lubrificantes (IUCLLG) foi substituído pelo Imposto sobre a Circulação de Mercadorias e Serviços (ICMS) de competência Estadual, enquanto o imposto sobre os serviços rodoviários de transportes e cargas foi substituído pelo Imposto sobre a Propriedade de Veículos Automotores (IPVA), também de competência Estadual. Apesar de as duas bases do Fundo Rodoviário Nacional terem sido transferidos para os Estados, não houve uma proporcional transferência da malha rodoviária a essa esfera da administração, de forma que o Governo Federal passou a sustentar a infraestrutura rodoviária com recursos orçamentários.

A Constituição de 1988 impôs um veto à vinculação das receitas de impostos para um fim específico, porém, permitiu a criação da Contribuição de Intervenção no Domínio Econômico, a Cide. Sob este pretexto, em 2001, instituiu-se a Cide-Combustível que incidia sobre a comercialização de petróleo e seus derivados, gás natural e seus derivados e o álcool combustível. Esta contribuição destinava-se, entre outras coisas, ao financiamento de programas de investimentos em infraestrutura de transportes, porém, Lacerda (2005) argumenta que nem sempre essa arrecadação era efetivamente gasta com o propósito para o qual foi constituída. Em 2004, com a Emenda Constitucional 44, $29 \%$ do valor arrecadado pela Cide-Combustível passou a ser alocado a estados e municípios (BRASIL, 2012b), e, em 2012, um novo decreto governamental zerou esta alíquota, de forma que os investimentos públicos em rodovias voltaram a depender do orçamento da União. Em 2015, a CideCombustível foi novamente restaurada pelo Decreto 8.395/2015 segundo o qual será cobrado $\mathrm{R} \$ 100$ para cada metro cúbico de gasolina e R\$50 para o do óleo diesel. ${ }^{12}$

Outra alternativa para estimular o desenvolvimento do setor rodoviário foi possibilitada pelo artigo 175 da Constituição Federal que, conforme já abordado anteriormente, permite que serviços públicos sejam delegados a parceiros privados mediante a licitação para contratos de concessão ou permissão. As Leis das Concessões e das PPPs surgiram com o intuito de atrair o capital privado para o investimento na infraestrutura e o setor rodoviário foi um dos pioneiros a colocar os novos regramentos em prática. Uma vantagem para o setor público de conceder uma rodovia é a possibilidade de que todo investimento seja pago mediante tarifas de pedágio cobradas diretamente do usuário final dos serviços, desonerando recursos

\footnotetext{
${ }^{12}$ Vale salientar que em 2015 também foram elevadas as contribuições a título de PIS e Cofins sobre a gasolina e o óleo diesel nos valores de, respectivamente, R\$120 e R\$ 100 para cada metro cúbico vendido.
} 
orçamentários dos investimentos na ampliação, recuperação, manutenção e operação das rodovias. A possibilidade de desonerar o orçamento público das responsabilidades relativas ao serviço de transporte rodoviário, somado à rentabilidade de diversos investimentos no setor, tem levado os governos a adotarem cada vez mais este modelo para garantir a continuidade do desenvolvimento do setor.

Nas alternativas brasileiras para a participação do setor privado a concessionária aufere renda mediante a cobrança de pedágios diretamente do consumidor final com ou sem a complementação de renda por meio de contraprestação pública. ${ }^{13}$ Em alguns países, um mecanismo bastante comum de remunerar o parceiro privado é através da instalação de um pedágio sombra ("shadow toll"), em que, conforme mencionado anteriormente, o parceiro privado é remunerado pelo governo de acordo com a demanda na rodovia. Esse mecanismo já foi implementado com sucesso em países como a Inglaterra, a Finlândia e a Holanda.

Guasch (2004) aponta que a participação privada no setor de infraestrutura é geralmente precedida de uma reestruturação e uma regulamentação setorial. Isso porque, para atrair o investimento privado, é preciso proteger os investidores das motivações políticas que podem influenciar a tomada de decisão do poder público. A existência de altos custos irrecuperáveis pode levar o administrador público a um comportamento oportunista e politicamente dirigido. Um cenário típico é aquele em que um político, buscando um aumento em sua popularidade, reduz as tarifas depois que os custos irrecuperáveis já foram incorridos pelo parceiro privado, ou ainda, quando o cronograma de obras é alterado para atender a um determinado calendário político.

O Brasil passou por uma série de mudanças institucionais até chegar ao modelo vigente. Neste atual cenário, o Ministério dos Transportes é responsável por elaborar a estratégia de longo prazo no setor de logística do país, assim como elaborar políticas públicas setoriais e monitorar seu andamento. Em 2001, por meio da Lei Federal $\mathrm{n}^{\mathrm{o}} 10.233$, o Governo Federal buscou reestruturar o setor de transportes no Brasil. Foram criadas duas autarquias que interagem com o transporte rodoviário, quais sejam, a Agência Nacional de Transportes Terrestres (ANTT) e o Departamento Nacional de Infraestrutura de Transportes (DNIT). O

\footnotetext{
${ }^{13}$ Conforme visto, a figura da contraprestação existe apenas na concessão administrativa ou patrocinada, não estando presente na concessão comum.
} 
primeiro é o responsável pela regulação e fiscalização da malha rodoviária concedida à iniciativa privada mediante a concessão ou permissão de exploração (FERREIRA, 2009). A agência possui independência administrativa e autonomia financeira, de forma a coibir as pressões políticas que incidem sobre os reguladores. Já o DNIT tem por objetivo implementar a política de infraestrutura rodoviária do país, operando, fazendo a manutenção, ampliando a capacidade ou restaurando a infraestrutura existente. O recurso do DNIT provém diretamente da União fazendo do departamento um órgão gestor e executor da política setorial sob a jurisdição Ministério dos Transportes (BRASIL, 2012a).

O Programa de Concessões de Rodovias Federais (PROCROFE) foi oficialmente lançado pela a Portaria Ministerial $\mathrm{n}^{\mathrm{o}} 10$ de 1993, modificada posteriormente pelas portarias $\mathrm{n}^{\mathrm{o}}$ 246/1994, 824/1994 e 214/1995. O PROCROFE era inicialmente de responsabilidade do hoje extinto Departamento Nacional de Estradas de Rodagem (DNER) e já em 1993 lançou-se o primeiro edital de licitação para a concessão de cinco trechos que já eram pedagiados diretamente pelo Ministério dos Transportes. Concomitante a esta Primeira Etapa do PROCROFE, o DNER identificou $11.191,1 \mathrm{~km}$ de trechos rodoviários também passíveis de serem concedidos. Os contratos dos cinco trechos licitados foram assinados entre 1995 e 1997 com duração entre 20 e 25 anos. Gonze (2014) aponta que nessa primeira etapa de concessões, os contratos eram semelhantes ao modo tradicional de contratação, em que o setor público determinava quais obras deveriam ser executadas e quais as técnicas a serem adotadas. Vale notar que no lançamento dos primeiros editais de licitação para as concessões rodoviárias, ainda inexistia um aparato institucional consolidado para regular as concessionárias, uma vez que, apenas em 2001 instituiu-se a ANTT (Agência Nacional de Transportes Terrestres), a agência reguladora das concessões federais (GONZE, 2014; BRASIL, 2015a).

Em 1996 a Lei Federal n ${ }^{0} 9.277$ possibilitou que Estados e Municípios solicitassem ao Governo Federal a delegação de trechos sob a jurisdição federal para que fossem incluídos nos seus próprios programas estaduais de concessão. São Paulo, Rio Grande do Sul, Santa Catarina e Paraná concederam diversas rodovias à iniciativa privada, com destaque para o Estado de São Paulo que tem mais de 5 mil km concedidos.

Em 2008, cerca de doze anos após a primeira rodada de concessões federais, a ANTT deu início a Fase Um da Segunda Etapa do PROCROFE em que foram licitados mais de $2 \mathrm{mil} \mathrm{km}$ 
de rodovias à iniciativa privada. O critério de seleção foi exclusivamente a menor tarifa básica de pedágio ofertada a partir de um programa de execução de obras estabelecido pelo governo. Nesta nova etapa buscou-se transferir ao parceiro privado mais responsabilidades na gestão da concessão, trazendo no contrato uma matriz de riscos que alocava a cada uma das partes um risco que deveria ser por eles gerenciados. Essa definição de risco havia sido muito preliminar na Primeira Etapa do programa, de forma que cabia à concessionária simplesmente o risco de demanda e eventuais falhas na execução das obras, tornando aqueles contratos muito restritos para a atualização tecnológica do setor. Na Segunda Etapa, além da ideia de matriz de riscos, foram introduzidos parâmetros de desempenho para o acompanhamento da execução das obras, porém, o foco dos parâmetros de desempenho ainda era o processo construtivo, e não o nível de serviços prestados pelas concessionárias. A Fase Dois da Segunda Etapa do programa contempla somente um projeto de concessão situado na Bahia e teve seu contrato assinado em 2009 (GONZE, 2014).

Em 2012, houve o lançamento do Programa de Investimentos em Logística (PIL) e as concessões previstas pela Terceira Etapa do PROCROFE acabaram sendo inseridas no contexto do PIL. A Terceira Etapa Fase Um do PROCROFE foi iniciada com a publicação e posterior cancelamento do edital para a concessão, de forma que, cronologicamente, a Fase Dois desta Etapa precede a Fase Um. A Fase Dois consistiu de um único lote que, originalmente, fazia parte da Segunda Etapa do programa, a saber, trecho da BR-101 que atravessa o Espírito Santo. O contrato desta Fase Dois da Terceira Etapa do programa é bastante similar aos contratos da Segunda Etapa, porém traz novidades importantes como a utilização do Fator X para estimular a eficiência das concessionárias e compartilhar seus ganhos de produtividade com os usuários do Sistema Rodoviário e a inserção, no programa de obras, do conceito de obras condicionadas ao volume de tráfego, que definem um gatilho de demanda a partir do qual determinadas obras devem ser executadas.

Os lotes das Fases Um e Três foram leiloados no segundo semestre de 2013 e as concessões destas Fases iniciaram-se no primeiro semestre de 2014. Nessa nova rodada de concessões, o governo brasileiro adotou uma estratégia para estimular a expansão dos investimentos nas rodovias exigindo a duplicação de toda extensão dos trechos concedidos até o quinto ano da concessão e a cobrança de pedágio inicia-se apenas após a conclusão de $10 \%$ dessas duplicações. Assim como nos lotes da Fase Dois da Terceira Etapa, usa-se, nas Fases Um e Três, o Fator X para compartilhar ganhos de eficiência entre os agentes e parâmetros de 
desempenho para acompanhar a execução contratual. A Figura 4 e a Tabela 2, a seguir, apresentam um resumo das concessões do PROCROFE com informações básicas de cada uma delas, assim como sua localização.

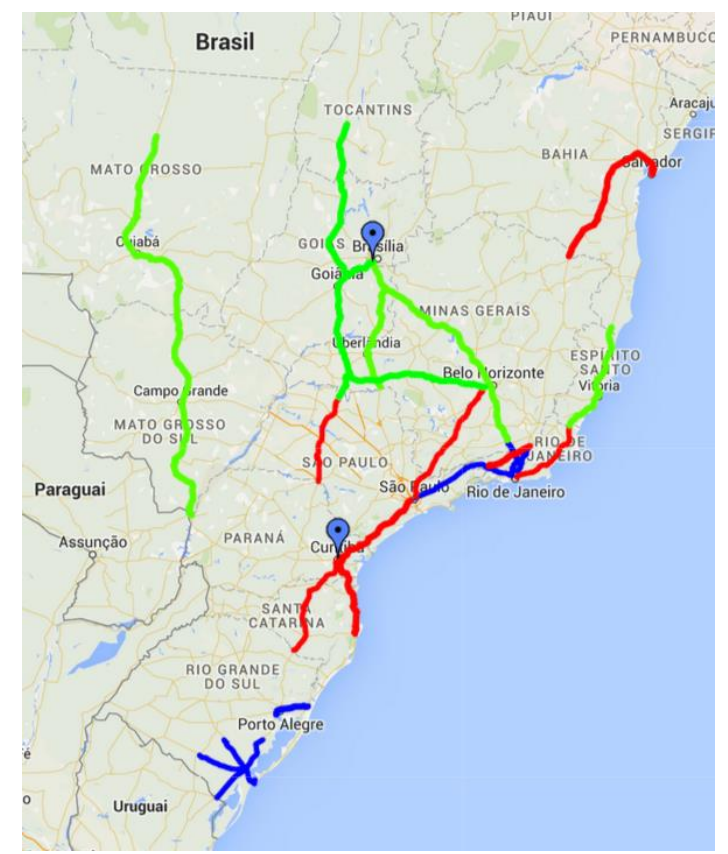

Figura 4 - Trechos concedidos pelo PROCROFE

Fonte: BRASIL (2015a)

Em 9 de junho de 2015, o Governo Federal lançou uma nova etapa de concessões em diversos setores da infraestrutura, incluindo novas concessões somando aproximadamente 7 mil km de rodovias com investimentos estimados de $\mathrm{R} \$ 66,1$ bilhões. O governo pretende leiloar quatro desses lotes ainda em 2015 e os 11 lotes restantes em 2016. Uma diferença anunciada para essa nova rodada de concessões é o incentivo às debêntures incentivadas com o intuito tornar o setor de infraestrutura menos dependente de financiamentos no BNDES (BRASIL, 2015b). 
Tabela 2 - Contratos de concessão do PROCROFE

\begin{tabular}{|c|c|c|c|c|c|}
\hline Rodovias & \begin{tabular}{|l|} 
BR-116/RJ/SP \\
(NOVADUTRA)
\end{tabular} & \begin{tabular}{|l}
$\mathrm{BR}-040 / \mathrm{MG} / \mathrm{RJ}$ \\
(CONCER)
\end{tabular} & BR-116/RJ (CRT) & \begin{tabular}{|l|} 
BR-290/RS \\
(CONCEPA)
\end{tabular} & $\begin{array}{l}\text { BR-116/293/392/RS } \\
\text { (ECOSUL) }\end{array}$ \\
\hline Data assinatura & $31 / 10 / 1995$ & $31 / 10 / 1995$ & $22 / 11 / 1995$ & 04/03/1997 & $18 / 07 / 1998$ \\
\hline Trecho & $\begin{array}{l}\text { Rio de Janeiro - São } \\
\text { Paulo }\end{array}$ & $\begin{array}{l}\text { Rio de Janeiro - Juiz } \\
\text { de Fora }\end{array}$ & $\begin{array}{l}\text { Rio de janeiro - } \\
\text { Teresópolis - Além } \\
\text { Paraíba } \\
\end{array}$ & Osório - Porto Alegre & Pólo de Pelotas \\
\hline Extensão (km) & 402 & 179,9 & 142,5 & 121 & 457,3 \\
\hline
\end{tabular}

\begin{tabular}{|c|c|c|c|c|c|c|c|c|}
\hline Rodovias & $\begin{array}{l}\text { BR-116/PR/SC } \\
\text { (AUTOPISTA } \\
\text { PLANALTO SUL) }\end{array}$ & \begin{tabular}{|l|} 
BR-116/PR - BR- \\
376/PR - BR 101/SC \\
(AUTOPISTA \\
LITORAL SUL) \\
\end{tabular} & $\begin{array}{l}\text { BR-116/SP/PR } \\
\text { (AUTOPISTA RÉGIS } \\
\text { BITTENCOURT) }\end{array}$ & $\begin{array}{l}\text { BR-381/MG/SP } \\
\text { (AUTOPISTA } \\
\text { FERNÃO DIAS) }\end{array}$ & $\begin{array}{l}\text { BR-101/RJ } \\
\text { (AUTOPISTA } \\
\text { FLUMINENSE) }\end{array}$ & $\begin{array}{l}\text { BR-153/SP } \\
\text { (TRANSBRASILIANA) }\end{array}$ & $\begin{array}{l}\text { BR-393/RJ } \\
\text { (RODOVIA DO AÇO) }\end{array}$ & $\begin{array}{l}\text { BR-116/324/BA e BA } \\
526 / 528 \text { (VIABAHIA) }\end{array}$ \\
\hline Data assinatura & $14 / 02 / 2008$ & $14 / 02 / 2008$ & $14 / 02 / 2008$ & $14 / 02 / 2008$ & $14 / 02 / 2008$ & $14 / 02 / 2008$ & $26 / 03 / 2008$ & $03 / 09 / 2009$ \\
\hline Trecho & Curitiba - Div. SC/RS & Curitiba - Palhoça & $\begin{array}{l}\text { São Paulo - Curitiba } \\
\text { (Régis Bitencourt) }\end{array}$ & \begin{tabular}{|} 
Belo Horizonte - São \\
Paulo (Fernão Dias)
\end{tabular} & $\begin{array}{l}\text { Ponte Rio-Niterói - } \\
\text { Div.RJ/ES }\end{array}$ & $\begin{array}{l}\text { Div.MG/SP - Div. } \\
\text { SP/PR }\end{array}$ & $\begin{array}{l}\text { Div. MG/RJ - Entr.BR- } \\
116 \text { (Dutra) }\end{array}$ & \begin{tabular}{|l|} 
Divisa BA/MG - \\
Salvador - Acesso à \\
Base Naval de Aratu \\
\end{tabular} \\
\hline Extensão (km) & 412,7 & 405,9 & 401,6 & 562,1 & 320,1 & 321,6 & 200,4 & 680,6 \\
\hline
\end{tabular}

\begin{tabular}{|c|c|c|c|c|c|c|c|c|c|}
\hline Rodovias & $\begin{array}{l}\text { BR-101/ES/BA (ECO- } \\
\text { 101) }\end{array}$ & $\begin{array}{l}\text { BR-050/GO/MG } \\
\text { (MGO Rodovias) }\end{array}$ & \begin{tabular}{|l|} 
BR- \\
060/153/262/DF/GO/ \\
MG (CONCEBRA) \\
\end{tabular} & BR-163/MS (MS VIA) & BR- 163/MT (CRO) & $\begin{array}{l}\text { BR-040/DF/GO/MG } \\
\text { (Via 040) }\end{array}$ & BR-153/TO/GO & \begin{tabular}{|l} 
BR-101/RJ \\
(ECOPONTE)
\end{tabular} & TOTAL \\
\hline Data assinatura & $17 / 04 / 2013$ & $05 / 12 / 2013$ & $31 / 01 / 2014$ & $12 / 03 / 2014$ & $12 / 03 / 2014$ & $12 / 03 / 2014$ & $12 / 09 / 2014$ & $18 / 05 / 2015$ & \\
\hline Trecho & $\begin{array}{l}\text { Entr. com a BA-698 } \\
\text { (acesso a Mucuri) - } \\
\text { Divisa ES/RJ }\end{array}$ & $\begin{array}{l}\text { Entr. com a BR-040 } \\
\text { (Cristalina/GO - } \\
\text { Divisa MG/SP) }\end{array}$ & \begin{tabular}{|l|}
$630,20 \mathrm{~km}$ da BR-060 \\
e BR-153, desde o \\
entr. com a BR-251, \\
no DF, até a divisa \\
MG/SP, e $546,30 \mathrm{~km}$ \\
da BR-262, do entr. \\
com a BR-153 ao \\
entr. com a BR-381, \\
em MG
\end{tabular} & $\begin{array}{l}\text { Trecho integralmente } \\
\text { inserido no estado do } \\
\text { MS (início na divisa } \\
\text { com o estado do MT } \\
\text { e término na divisa } \\
\text { com o PR) }\end{array}$ & \begin{tabular}{|l|} 
Trecho de $822,8 \mathrm{~km}$ \\
na BR-163 e 28,1 km \\
na MT-407 (início na \\
divisa com o estado \\
do MS e término no \\
km 855,0, no \\
entroncamento com a \\
MT-220)
\end{tabular} & $\begin{array}{l}\text { Trecho Brasília/DF - } \\
\text { Juiz de Fora/MG }\end{array}$ & $\begin{array}{l}\text { Trecho Anápolis/GO } \\
\text { (BR-060) até Aliança } \\
\text { do Tocantins/TO (TO- } \\
\text { 070) }\end{array}$ & Ponte Rio-Nlterói & 21 Trechos \\
\hline Extensão (km) & 475,9 & 436,6 & $1.176,50$ & 847,2 & 850,9 & 936,8 & 624,8 & 13,2 & $9.969,60$ \\
\hline
\end{tabular}

Fonte: BRASIL (2015a) 


\subsection{Seleção da modalidade de contratação}

Após apresentar algumas modalidades de contratação previstas pela teoria econômica e, em particular, suas regulamentações na legislação brasileira, a questão que se coloca é: como decidir qual o modelo mais apropriado para cada projeto? Deve-se tomar cuidado neste ponto, pois a discussão pode, muitas vezes, tender para um debate político sobre o papel do Estado e a conveniência de conceder ao setor privado serviços eminentemente públicos. Apesar de importante, estas questões fogem ao escopo desse trabalho, que busca concentrar-se nos prós e contras da participação privada na oferta e no financiamento de infraestrutura.

A partir de 1990, o setor privado tem participado cada vez mais ativamente na provisão de infraestrutura por meio de diferentes modelos de parcerias entre o setor público e privado. Tentando avaliar o impacto dessa participação privada na infraestrutura, Percoco (2012) acrescenta o montante de investimentos em infraestrutura por meio de PPPs como regressor em um modelo de crescimento. Utilizando dados de 81 países entre os anos de 1991 e 2008, o autor encontra que o montante de investimentos através de parcerias entre poder público e setor privado estimula o crescimento, porém, apenas em países considerados de alta renda, o que, segundo o autor, pode ser um indicativo de que as PPPs apenas induzem crescimento em países com boas instituições e arcabouço regulatório mais consolidado. ${ }^{14}$

Blanc-Brude et al. (2006) estimam que o custo de rodovias construídas por meio de concessões ${ }^{15}$ são em geral $24 \%$ mais caras que aquelas construídas através de métodos tradicionais de contratação. Porém, os autores argumentam que a construção por esse tipo de PPP torna-se mais cara no curto prazo, pois o parceiro privado considera os custos do projeto ao longo de todo seu ciclo de vida, enquanto na contratação tradicional avalia-se simplesmente o custo de implementação do projeto, atentando-se pouco para os custos operacionais e de manutenção futuros (nos modelos brasileiros tanto as concessões como as PPPs são contratos de longo prazo que permitem que o parceiro privado contabilize os custos de todo ciclo de vida do projeto). Além disso, o parceiro privado de uma parceria com o setor público deve precificar todos os riscos envolvidos no projeto que são a ele alocados, enquanto

\footnotetext{
${ }^{14} \mathrm{Na}$ regressão, o autor interage o volume de investimentos através de PPPs com um indicador de qualidade das instituições (fornecido também pelo Banco Mundial) e fortalece a tese de que as PPPs são mais efetivas quanto melhor a qualidade institucional do país.

${ }^{15}$ Em particular aqueles modelos de concessão em que o parceiro privado é responsável pelo projeto, construção, operação e financiamento do empreendimento (DBOF).
} 
na contratação tradicional, diversos riscos são absorvidos pelo poder público e pelo contribuinte, não sendo contabilizados nos custos.

Engel et al. (2010) avaliam a diferença entre a provisão pública ou por meio de Parceria Público-Privada (em seu sentido mais abrangente) da infraestrutura. Os autores também defendem que sob PPPs, o setor privado cobra pelo risco do projeto, enquanto o setor público é capaz de suprimir o fracasso de projetos à custa do contribuinte. Uma vantagem observada na provisão privada é que a empresa internaliza o custo de todo o ciclo de vida do projeto, suportando investimentos em qualidade mais elevados na construção para arcar com custos de operação e manutenção mais baixos no futuro. Na provisão pública, em geral tem-se um agente construindo e outro operando, o que, somado a um processo licitatório de menor custo, gera incentivos a subinvestimentos em qualidade. Além disso, parte dos riscos associados às PPPs reflete o emaranhado de contratos que cercam as Sociedades de Propósito Específico (SPE).

Aschauer (2000) levanta a questão do financiamento da infraestrutura, apontando que este é um ponto fundamental quando se discute seus os impactos. Este tópico tem sido bastante discutido na literatura. Pereira e Ferreira (2011) analisam quatro alternativas para reverter o cenário de baixo investimento em infraestrutura no Brasil:

i. Aumentar o investimento por meio de um aumento da dívida pública;

ii. Realocar parte dos gastos correntes do governo para este tipo de investimento;

iii. Aumentar a arrecadação de impostos do governo; e

iv. Financiar o investimento por meio de taxas cobradas dos usuários de serviços públicos.

Os autores elaboram um modelo de equilíbrio geral, calibrado com dados brasileiros, para avaliar ganhos de produto e de bem-estar de uma expansão desta última alternativa. Eles encontram um grande potencial de expansão do produto e do bem estar sob este cenário. Duas simulações são feitas. Na primeira, a arrecadação pela taxa cobrada do usuário é utilizada para reduzir os impostos sobre o investimento em capital privado. $\mathrm{Na}$ segunda, essa renda é utilizada para subsidiar o investimento privado em infraestrutura. Ambas alternativas apresentam potencial de melhoria de bem estar, porém, na segunda, este potencial é maior, visto que novos investimentos em infraestrutura possuem externalidades. 
Giesecke et al. (2008) buscavam entender um problema parecido ao estudado no presente trabalho. Naquela ocasião, os autores avaliaram o impacto de diferentes formas de financiamento da infraestrutura urbana. Foi utilizado um modelo dinâmico multi-regional de equilíbrio geral computável para estudar o impacto líquido sobre o emprego de New South Wales (NSW) de quatro formas alternativas de financiamento de um programa de investimentos, são elas: uma elevação dos impostos sobre os salários, financiamento por dívida (paga em 20 anos com imposto sobre salário), imposto sobre o investimento imobiliário e um imposto sobre a propriedade.

Com as simulações, o trabalho conclui que os maiores ganhos líquidos acontecem no financiamento por dívida ou pelo imposto sobre a propriedade, enquanto no imposto sobre os salários e sobre o investimento, os resultados são bem menos expressivos, tendo impacto líquido negativo sobre o emprego nos 12 e 19 primeiros anos, respectivamente. Os quatro cenários de simulação são construídos a partir da sobreposição de três choques exógenos distintos:

i. Choque de demanda no setor de construção civil representando a expansão dos gastos do governo para financiar o programa, cujo valor é de \$ 1 bilhão por ano;

ii. Choque ocasionado pelos benefícios advindos do investimento em infraestrutura. Os autores consideram que o investimento em infraestrutura aumenta a produtividade local; e

iii. Choque do financiamento que depende de qual cenário está sendo avaliado.

Os quatro cenários compartilham os choques (i) e (ii), porém, de acordo com o tipo de financiamento sendo estudado, soma-se a eles o choque (iii) específico.

Também avaliando um problema próximo ao que se pretende no presente trabalho, Kim et al. (2011) avaliam diferentes alternativas para financiar a construção de uma rodovia que passa por diferentes províncias da Coreia do Sul. Os autores simulam duas situações, uma em que todo o país financia as rodovias por meio de um imposto sobre a renda e outra em que cada região financia apenas a sua parcela da rodovia, utilizando também impostos sobre a renda. $\mathrm{O}$ estudo usa um modelo dinâmico multi-regional de equilíbrio geral computável integrado a um 
modelo de transportes para avaliar o impacto das novas rodovias. O modelo considera o país dividido em quatro regiões distintas além de uma região externa, e, além disso, especifica o comportamento de uma família representativa por região, quatro produtores por região produzindo um único produto cada, um governo local e um governo central. Os autores encontram que a cobrança localizada tem um maior impacto no crescimento da renda do país e na redução de desigualdades regionais.

Ainda estudando formas de financiamento, Boccanfuso et al. (2014) utilizam um modelo de equilíbrio geral com dinâmica recursiva para avaliar alternativas para a expansão da infraestrutura em Quebec. O programa em análise consiste em um investimento de $\$ 1$ bilhão por ano ao longo de cinco anos e são construídos quatro cenários com alternativas para o seu financiamento. Cada alternativa é comparada a um cenário base em que inexiste tal programa de investimento. As alternativas de financiamento são apresentadas a seguir:

i. $\quad 100 \%$ do valor financiado por meio da contração de dívida;

ii. Parte do investimento é financiado por meio da expansão da dívida enquanto a outra parte é financiada por meio de um incremento de um imposto sobre as vendas;

iii. Parte do financiamento é por meio de dívida e parte é por meio de um imposto sobre a renda das famílias;

iv. Parte do investimento financiado por meio de dívida e outra parte por imposto sobre a renda das firmas.

O modelo utilizado considera 24 setores produtores e quatro agentes, a saber, uma família representativa, uma firma privada, o governo e o setor externo. A função de produção das firmas é modelada por uma estrutura aninhada Leontieff/CES em que a externalidade provocada pela expansão da infraestrutura reflete-se em um parâmetro de eficiência na função CES que irá gerar o valor agregado por cada firma através de uma combinação entre capital e trabalho. Os autores concluem que existe pouca diferença em termos de crescimento agregado do PIB entre as alternativas, porém, entre os três tipos de impostos para complementar o financiamento, o imposto sobre a renda das famílias mostra-se a melhor opção, enquanto o imposto sobre as firmas parece a pior das opções. 
A diferença entre as várias modalidades de contratação de um projeto de infraestrutura pode ser estudada por diversas óticas, como por exemplo, a eficiência dos investimentos, a complexidade da contratação, a precificação e a alocação dos riscos, a velocidade de implementação do projeto, seu impacto no mercado de crédito para outros setores da economia, etc. Apesar dessa miríade de possibilidades, este estudo está primordialmente interessado nos impactos da decisão sobre quem irá pagar por determinado projeto de infraestrutura rodoviária, seu usuário direto ou o contribuinte mediante impostos pagos ao governo. Ao ignorar as diferenças existentes entre as modalidades de contratação, o exercício proposto neste trabalho compara duas situações: (i) concessão comum financiada mediante a cobrança de pedágio diretamente do usuário final; e (ii) concessão comum financiada por meio de um pedágio sombra, em que o governo é quem irá pagar uma tarifa de pedágio à concessionária por meio de um imposto arrecadado de todo o país. A segunda situação seria equivalente a uma empreitada comum executada diretamente pelo estado caso inexistissem fatores como a diferença de eficiência entre setor público e privado, a diferença na qualidade dos serviços prestados, custo de financiamento, a velocidade de execução da obra e etc. Nesse sentido, ao comparar a concessão comum com a situação de pedágio sombra, pode-se focar exclusivamente na matéria de interesse desta pesquisa, qual seja, o impacto econômico da decisão sobre quem financiará o projeto, o usuário final da rodovia, ou o governo.

$\mathrm{Na}$ próxima seção, apresenta-se a metodologia empregada para o desenvolvimento do presente estudo. Serão discutidas as principais características do modelo inter-regional de equilíbrio geral computável utilizado e serão apresentados alguns trabalhos que se valeram de tal ferramenta para analisar a questão dos transportes na economia. 


\section{METODOLOGIA}

Inspirado no paradigma de modelagem da Nova Geografia Econômica (KRUGMAN, 1998), este trabalho utiliza um modelo de equilíbrio geral para avaliar as diferentes formas de financiar a infraestrutura rodoviária. Porém, diferente de Pereira e Ferreira (2011), o modelo de equilíbrio geral utilizado no presente estudo considera as distintas regiões do país e a interação entre elas, caracterizando um modelo inter-regional de equilíbrio geral. Para tanto, será utilizado o B-MARIA (do inglês Brazilian Multisectoral And Regional-Interregional Analysis Model), primeiro modelo inter-regional de equilíbrio geral computável totalmente operacional para a economia brasileira (Haddad, 1999).

Os modelos de equilíbrio geral, em contraste com modelos de equilíbrio parcial, são desenhados para avaliar o equilíbrio da economia em um ambiente que todos agentes estão interagindo simultaneamente. Por muito tempo esta ferramenta foi considerada simplesmente uma possibilidade teórica, pois a inexistência de capacidade computacional impossibilitava o desenvolvimento de um sistema capaz de analisar a economia como um todo. Em 1960, Johansen iniciava os estudos práticos com modelos de equilíbrio geral, analisando o crescimento multi-setorial da economia da Noruega através da matriz de insumo-produto do país (DIXON e PARMENTER, 1996).

Com o avanço do poder computacional tornou-se possível analisar modelos de Equilíbrio Geral Computável (EGC) bastante complexos, popularizando esta ferramenta como instrumento de análise e avaliação de políticas. Este campo de estudos apresenta oportunidades para pesquisadores tanto teóricos quanto empíricos. Na parte teórica, permanece o constante desafio de incorporar aos modelos de EGC os mais novos avanços da teoria econômica, enquanto aos pesquisadores empíricos cabe a tarefa de validar os modelos e encontrar dados e parâmetros para alimentá-lo.

A abordagem mais comum para a resolução de problemas de equilíbrio geral segue a metodologia de Johansen/Euler. As características da economia são representadas por um vetor de variáveis $V$ de tamanho $n$ de forma que:

$$
\mathrm{F}(\mathrm{V})=0
$$


F é um vetor de $m$ funções que caracterizam as interações entre as variáveis da economia. Para que o sistema possua solução, ele deve possuir mais variáveis que equações, ou seja, n > m. Assume-se que existam: $(n-m)$ variáveis exógenas; $m$ variáveis endógenas; e um vetor de variáveis conhecidas $\mathrm{V}_{\mathrm{i}}$, tal que:

$$
\mathrm{F}\left(\mathrm{V}_{\mathrm{i}}\right)=0
$$

$\mathrm{O}$ vetor de variáveis iniciais $\left(\mathrm{V}_{\mathrm{i}}\right)$ pode ser dividido em duas partes, a saber, as variáveis exógenas $\left(\mathrm{V}_{1}\right)$ e as endógenas $\left(\mathrm{V}_{2}\right)$. Uma simulação com um modelo de equilíbrio geral consiste em aplicar um choque nas variáveis exógenas e encontrar qual o novo ponto de equilíbrio das variáveis endógenas do sistema. Para uma descrição mais detalhada sobre esse tipo de modelo e sua estrutura matemática, recomenda-se a leitura de Dixon e Parmenter (1996).

Após esta breve introdução sobre modelos de equilíbrio geral a próxima seção irá apresentar o modelo que é utilizado para as simulações desta pesquisa.

\subsection{Modelo Inter-regional de Equilíbrio Geral Computável para a economia brasileira}

O modelo Inter-regional de Equilíbrio Geral Computável (IEGC) aqui utilizado pertence à família B-MARIA (HADDAD, 1999), já bastante consolidada para a economia brasileira. Os modelos da família B-MARIA seguem a tradição australiana de modelagem de equilíbrio geral, em que as soluções surgem da forma linearizada das equações que descrevem a economia. ${ }^{16}$ A flexibilidade garantida pela modelagem permite aos pesquisadores utilizarem esta ferramenta para a avaliação de uma miríade de problemas econômicos apenas com pequenas adaptações.

Duas inovações desenvolvidas em Haddad (2004) expandiram o poder analítico dos modelos da família B-MARIA para a avaliação do impacto de políticas de transporte, são elas: retornos de escala nas funções de produção regional e as inovações no tratamento do custo de transporte, que possibilitaram acoplar ao IEGC um modelo externo de transportes. Neste

\footnotetext{
${ }^{16}$ Em contrapartida à tradição australiana, existe a tradição americana de equilíbrio geral, que utiliza algoritmos para solucionar as equações não lineares. O esforço computacional exigido por essa modelagem é muito maior, de forma que os modelos têm uma complexidade e um detalhamento ainda limitado.
} 
trabalho, a fim avaliar a potencialidade analítica da metodologia proposta, o autor realiza dois exercícios de especial interesse para o presente estudo: (i) simula uma redução generalizada nos custos de transportes entre e dentro das regiões brasileiras contempladas; e (ii) avalia os impactos econômicos da duplicação da rodovia Fernão Dias (BR-381), que liga São Paulo à capital mineira. São avaliados os impactos no PIB e variação equivalente tanto ao nível regional quanto nacional o que ressalta o poder da ferramenta em apoiar o planejamento de políticas públicas e, em particular, quando se trata de política de transportes.

A modelagem proposta tem sido colocada à prova tanto no mundo acadêmico quanto na efetiva elaboração de políticas públicas. No âmbito acadêmico, Haddad et al. (2008) avaliam duas rodovias de Minas Gerais e, fugindo do escopo da economia brasileira, Haddad et al. (2011) utilizam a metodologia proposta para uma avaliação da economia colombiana, estudando os impactos econômicos de uma melhoria generalizada na infraestrutura de transportes do país. No âmbito de planejamento de políticas públicas, variantes do modelo também foram utilizados para suportar a execução do já citado PNLT de 2007 do Ministério dos Transportes e dos planos de transporte do Estado de Minas Gerais, o PELT-MG, e também do estado do Pará, PELT-PA. ${ }^{17}$

\subsubsection{Aspectos teóricos do B-MARIA-MG}

O modelo que será utilizado é o mesmo utilizado em Haddad et al. (2008), uma extensão do modelo desenvolvido em Haddad (2004). A economia divide-se em 109 regiões, sendo 75 no Estado de Minas Gerais, 34 no restante do Brasil, e uma região externa. Os agentes da economia são modelados ao nível regional e o modelo segue uma abordagem bottom-up, ou seja, os agregados nacionais são construídos a partir dos resultados regionais dos choques em análise. Os agentes em cada região são: produtores, investidores, uma família representativa e um governo regional. Além disso, existe um governo central (federal) e o setor externo que interagem com cada uma das regiões. Consideram-se oito setores produtivos e de investimento, em que cada produtor utiliza capital, trabalho e terra como insumos primários. Os setores definidos são apresentados na Tabela 3 a seguir.

\footnotetext{
${ }^{17}$ PELT: Programa Estadual de Logística e Transportes.
} 
Tabela 3 - Setores da economia

\begin{tabular}{|l|}
\hline SETORES \\
\hline Agricultura \\
\hline Mineração \\
\hline Indústria de transformação \\
\hline Construção \\
\hline Transporte \\
\hline Comércio \\
\hline Administração pública \\
\hline Outros serviços \\
\hline Fonte: Elaboração própria
\end{tabular}

Conforme salientado em Haddad et al. (2008), alguns elementos estruturais assinalam as características inter-regionais do modelo. Define-se o fluxo inter-regional de bens e serviços; no longo prazo permite-se a movimentação inter-regional de fatores primários (trabalho e capital); mercadorias transportadas entre regiões são acometidas por um custo de transporte baseado em pares de Origem-Destino (O-D); e os agentes são localmente definidos. O núcleo do modelo é composto por equações que determinam oferta e demanda de agentes otimizadores, além de definirem as condições de equilíbrio dos mercados. Outros blocos de equações podem ser acrescidos ao núcleo do modelo para representar outras características de interesse da economia, entre eles destaca-se: o módulo de acumulação de capital e investimento, bloco de migração e mercado de trabalho, módulo de finanças públicas, etc. (HADDAD, 2004).

\subsubsection{O núcleo do B-MARIA-MG}

O núcleo do modelo é definido pelas equações básicas de comportamento dos agentes otimizadores da economia, além de garantir o equilíbrio de mercado entre oferta e demanda de cada bem e serviço (market clearing). Nesta seção do modelo, também são calculados diversos agregados nacionais e o nível de equilíbrio de preços. 


\subsection{Produtores}

Assume-se no modelo que existe uma firma representativa em cada setor de cada região da economia e que cada uma delas produz apenas um tipo de produto. As firmas minimizam seus custos através de uma estrutura aninhada de tecnologia de produção modelada em três estágios (Figura 5). No primeiro estágio, adota-se a hipótese de proporções fixas dos insumos intermediários e fatores primários através de uma função de Leontief. No segundo, os insumos intermediários importados são considerados substitutos imperfeitos daqueles produzidos domesticamente. No lado dos fatores primários, uma função CES (Constant Elasticity of Substitution) determina a quantidade de cada um dos três tipos de fatores da economia (capital, trabalho e terra) podendo esta função ser acometida ou não por efeitos de escala, a depender da configuração dos parâmetros. No terceiro estágio, os insumos domésticos são divididos entre as diferentes regiões produtoras do país. ${ }^{18}$ É importante salientar que a substituição de um bem produzido localmente por um produzido externamente é captada pela elasticidade de Armington, que mede a propensão de um consumidor alterar a origem dos bens por ele consumidos como resposta a uma alteração da relação entre o preço desse bem produzido no local e de seu preço de importação (de outras regiões ou países, o que inclui não só o preço de produção, como também o de transporte).

\footnotetext{
${ }^{18}$ Em determinadas especificações, o fator trabalho pode estar dividido em diferentes ocupações, porém, no modelo utilizado neste estudo, não se faz esta distinção.
} 


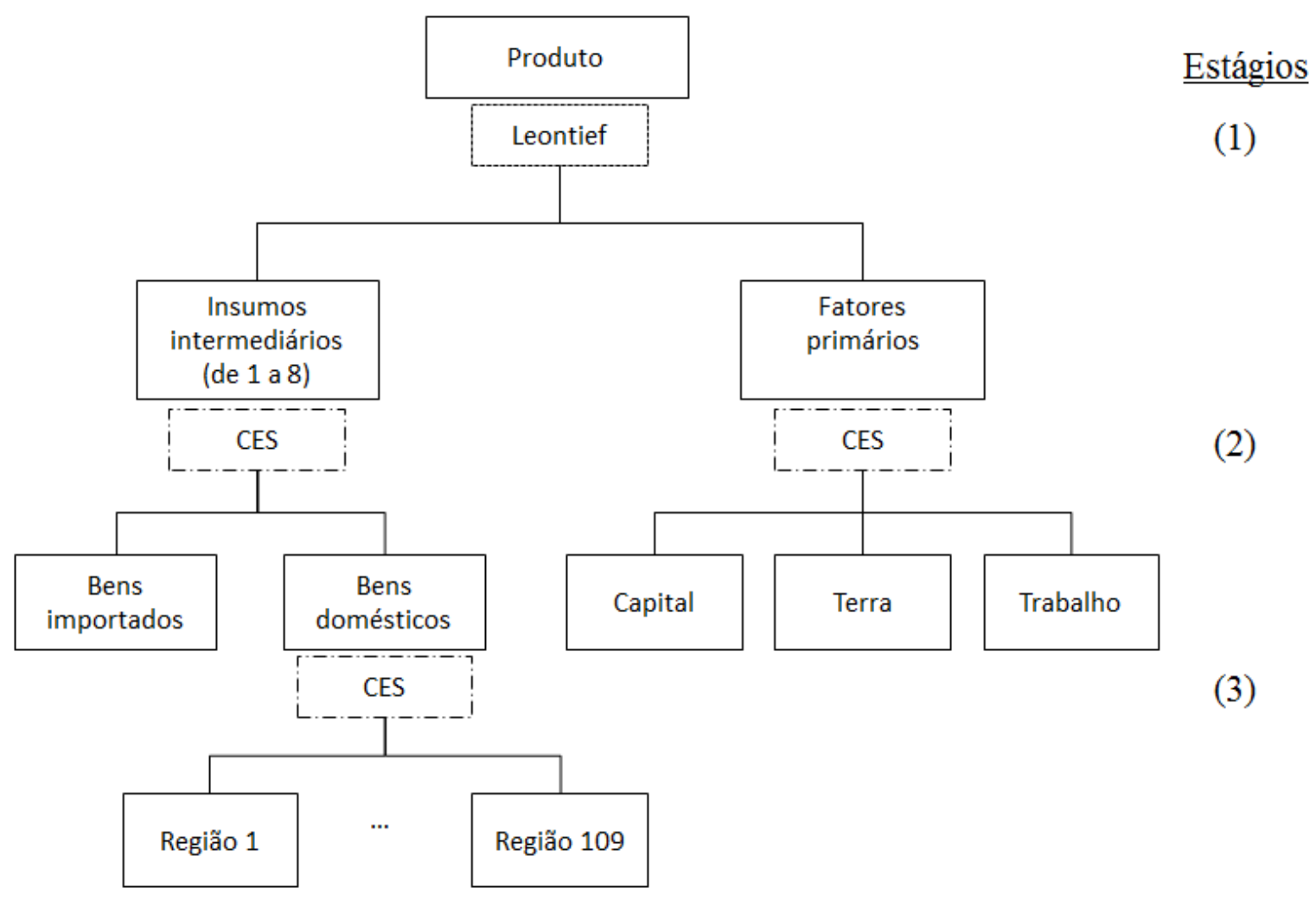

Figura 5 - Estrutura aninhada de produção

Fonte: Elaboração própria baseada em Haddad (1999)

\subsection{Família representativa}

A demanda das famílias segue uma função de utilidade aninhada do tipo Stone-Geary/CES que é maximizada para a renda disponível do consumidor (Figura 6). No primeiro estágio, a escolha é feita entre os distintos bens disponíveis por meio da função de Stone-Geary. ${ }^{19}$ No segundo estágio, cada bem é selecionado dentre opções de bens domésticos ou importados. No último estágio, os bens domésticos são selecionados dentre as firmas das distintas regiões produtoras.

\footnotetext{
${ }^{19} \mathrm{Na}$ função de utilidade Stone-Geary a família representativa aufere utilidade apenas a partir de um determinado nível de consumo de subsistência.
} 


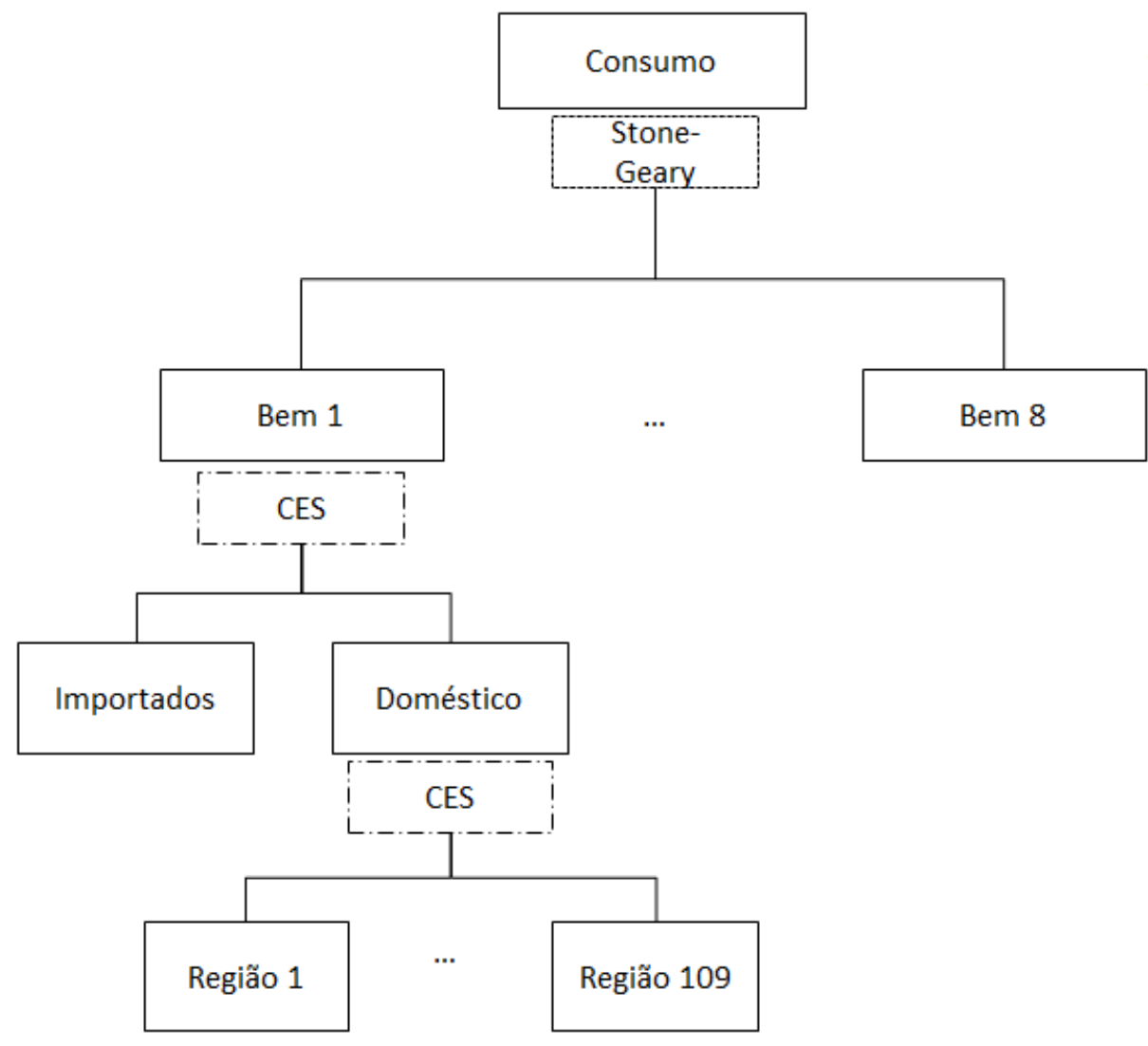

$\underline{\text { Estágios }}$

(1)

(2)

Figura 6 - Função de utilidade aninhada das famílias

Fonte: Elaboração própria baseada em Haddad (1999)

\subsection{Investidores}

Para a criação de novas unidades de capital, os investidores da economia têm uma modelagem análoga àquela dos produtores. O primeiro nível da sua função também é uma função Leontief de proporções fixas, porém, ao contrário das firmas, nesse estágio não são utilizados fatores primários, apenas bens intermediários (Figura 7). No segundo estágio da função, os bens intermediários são selecionados, através de uma CES, de produtores domésticos ou importados. No terceiro estágio, os bens domésticos das diversas regiões produtoras são considerados substitutos imperfeitos e uma CES seleciona quanto será utilizado de cada região. Vale observar que a demanda dos investimentos gera pressão sobre os fatores primários apenas indiretamente, uma vez que eles não são diretamente usados pela função de produção dos investimentos, mas sim para produzir os bens intermediários utilizados no investimento. 


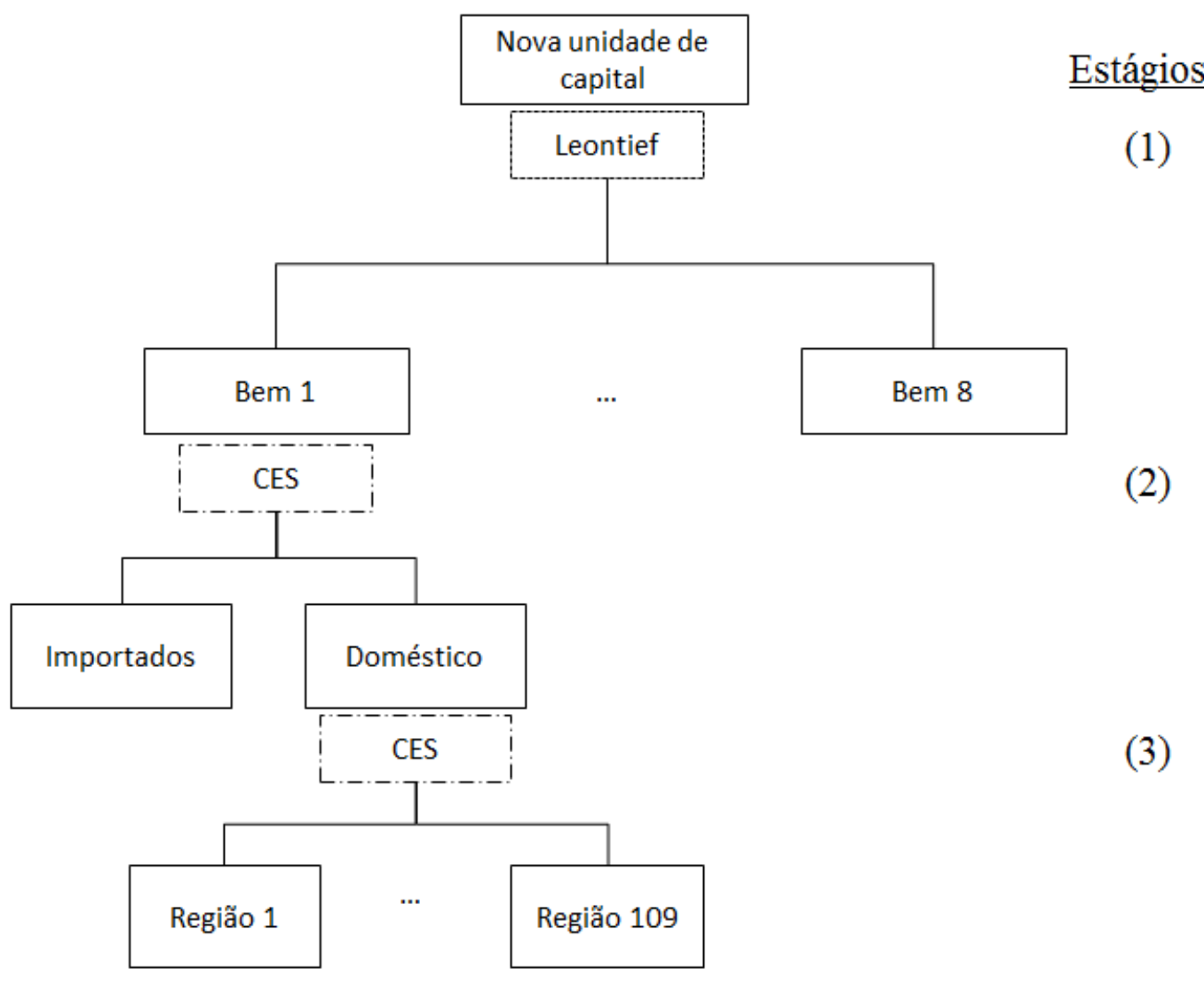

Figura 7 - Estrutura de otimização dos investidores

Fonte: Elaboração própria baseado em Haddad (1999)

\subsection{Demais usuários do modelo}

Os oito produtos da economia classificam-se em tradables (bens de tradição de exportação) e non-tradables (bens que não são exportados). A demanda externa por cada bem doméstico tradicionalmente exportado é definida por uma curva negativamente inclinada no preço internacional do próprio bem. Definem-se elasticidades da demanda externa por cada bem para alterações no preço F. O. B. (Free on Board) de cada produto de exportação regional. As elasticidades são diferentes entre cada bem, porém, são constantes entre as regiões, o que assume que um consumidor externo não tem preferências entre as diferentes regiões do Brasil. Os bens não exportados tradicionalmente são agrupados em uma cesta cuja demanda internacional está negativamente inclinada no seu preço do mercado internacional..

Cada região estará ainda sobre a influência das demandas de dois níveis de governo, o central (Federal) e o regional. O consumo desses agentes mantém uma relação constante com o 
consumo privado em suas respectivas esferas de atuação, assim, o consumo do governo regional varia conforme variações no consumo de sua região, enquanto o consumo do Governo Federal varia conforme alterações no consumo agregado do país.

\subsubsection{Acumulação de capital e investimento}

Neste bloco do modelo estão definidas as relações entre o investimento e o estoque de capital em determinado setor e região. As simulações em estática comparativa que serão utilizadas buscam avaliar o novo equilíbrio do modelo para um dado choque exógeno, de forma que a dinâmica de transição entre um e outro equilíbrio não é explicitamente modelada.

Define-se, porém, que existe uma relação entre a criação de capital em determinado setor e região e a taxa de retorno por ele proporcionada. Tal taxa de retorno mede a relação entre o aluguel do capital e seu custo de produção, de tal forma, que, uma expansão no retorno do capital em determinado setor e região acima do retorno sobre o capital da economia irá atrair mais investimentos para o setor e região em questão.

\subsubsection{Os custos de transporte e a demanda por bens margem}

O transporte é considerado como bem margem na economia, ou seja, ele existe para auxiliar no fluxo de outros bens. Um produto produzido em determinada região e consumido em outra deverá ser transportado da região produtora à consumidora, e é neste ponto que o bem margem, ou margem de transporte, torna-se importante. Considera-se que a margem é produzida no local de consumo do produto, exceto nos casos de exportação, quando então, a região produtora deverá produzir a margem de transporte. A demanda por margem entre um par de O-D é proporcional ao fluxo de bens percorrendo essa rota. Além disso, na sua função de demanda inclui-se um componente de mudança técnica que será essencial na ligação entre o IEGC e um modelo de transportes georreferenciado externo ao modelo de equilíbrio geral. A equação da demanda por margem segue abaixo:

$$
X \operatorname{MARG}(i, s, q)=\operatorname{AMARG}(i, s, q) *\left[\eta(i, s, q) * X(i, s, q)^{\theta(i, s, q)}\right]
$$


onde XMARG(i,s,q) é a demanda por margem de transporte gerada pelo transporte do produto $i$ entre a região produtora $s$ e a consumidora $q$. AMARG(i,s,q) é a variável tecnológica relacionada ao transporte entre as regiões $s$ e $q . \eta(\mathrm{i}, \mathrm{s}, \mathrm{q})$ é o coeficiente de margem sobre o fluxo de produto $\mathrm{X}(\mathrm{i}, \mathrm{s}, \mathrm{q})$, ou seja, faz a ligação entre a quantidade de produto sendo transportado e a necessidade de margem que ela gera. $\theta(\mathrm{i}, \mathrm{s}, \mathrm{q})$ é um parâmetro de escala do setor de transportes.

O custo do transporte surge na produção de XMARG(i,s,q), uma vez que este setor deve consumir tanto bens intermediários, quanto fatores primários (capital e trabalho) da economia, concorrendo com o resto da sociedade por estes recursos. Reescrever a equação da margem de transportes de outra forma traz boas intuições sobre este bem:

$$
\frac{X M A R G(i, s, q)}{X(i, s, q)^{\theta(i, s, q)}}=\operatorname{AMARG}(i, s, q) * \eta(i, s, q)
$$

As variáveis XMARG(i,s,q) e X(i,s,q) pertencem ao conjunto de dados iniciais do problema. No processo de calibragem do modelo, calcula-se $\eta(i, s, q)$ que irá representar, para cada fluxo de bens, quanto de margem é necessário. Percebe-se também o funcionamento da variável tecnológica exógena AMARG que muda a relação entre margem e fluxo de bens. Um choque positivo de tecnologia (que no modelo deve ser inserido como uma variação negativa de AMARG) irá diminuir a quantidade de margem necessária para transportar um determinado fluxo de bens, tornando o setor mais eficiente e o transporte menos custoso.

A variável AMARG faz a ponte entre o modelo de externo de transportes e o IEGC, traduzindo variações no tempo de deslocamento entre pares de origem-destino, em variações nos custos de transporte. O modelo de transporte mapeia o tempo mínimo de deslocamento entre cada par de O-D antes e depois de uma intervenção na estrutura rodoviária. Com dados de custos de transportes, estima-se uma função que transforme o tempo de viagem entre dois pontos em custo de transporte entre eles e, com isso, encontra-se a matriz de custo de transporte entre cada par da matriz O-D para um momento anterior e um posterior a intervenção na estrutura rodoviária. Calcula-se a variação nos custos de transporte para cada par da matriz O-D e define-se tal variação como o choque exógeno da variável AMARG do 
IEGC. Assim, variações nos custos de transportes calculados pelo modelo de transportes são traduzidas para o modelo IEGC como variações exógenas da variável AMARG (este procedimento será melhor detalhado na apresentação do estudo de caso na seção 4.2).

\subsubsection{Dados}

Uma etapa desafiadora das simulações de equilíbrio geral consiste na calibragem do modelo, que deve garantir a consistência dos dados. As informações contidas nos bancos de dados devem representar um equilíbrio inicial do sistema, o qual será perturbado pelos choques exógenos que levarão o sistema para outro equilíbrio. Os coeficientes das equações devem ser ajustados para garantir que os dados iniciais estejam em equilíbrio.

Os dados utilizados para calibrar o modelo aqui utilizado representam a economia brasileira no ano de 2002 e provêm de dados nacionais como matriz insumo-produto, comércio exterior, impostos, margens e tarifas disponíveis no IBGE que foram agrupados em uma matriz de contabilidade social inter-regional cuja estruturação foi elaborada pela FIPE (2007, apud HADDAD et al. 2008) como subsídio a execução do PELT-MG. Adams et al. (1994) argumentam que, desde que mantida a estrutura básica da economia, a defasagem dos dados não representa um problema para os exercícios de estática comparativa, uma vez que o equilíbrio final é comparado com um cenário base inicial.

\subsubsection{Medida de bem estar}

Assim como em outros modelos da família B-MARIA, no intuito de captar variações de bem estar advindas das intervenções na economia é possível avaliar a Variação Equivalente dos consumidores de cada região, assim como esse valor agregado nacionalmente. Segundo MasColell et al. (1995), essa medida de bem-estar pode ser compreendida como o valor monetário que deveria ser entregue a um consumidor para deixa-lo indiferente entre receber o dinheiro sem que a política em análise seja implementada, ou não recebe-lo com a política sendo implementada. Em outras palavras, é a variação na sua dotação orçamentária de um consumidor que lhe traz a mesma variação de utilidade causada pela implementação da política sendo estudada. Dessa forma, uma alteração nos preços que impacta negativamente o consumidor será equivalente a uma retirada de sua situação orçamentária inicial, de forma que a variação equivalente será negativa. 


\subsubsection{Fechamento}

Para realizar uma simulação em um modelo de EGC, deve-se estruturar o ambiente de simulação de acordo com os objetivos que se pretende observar na simulação. A literatura de EGC convencionou denominar esta etapa de preparação do modelo de fechamento. Em geral, dois tipos de fechamentos são mais usuais, a saber, o fechamento de curto e de longo prazo. $\mathrm{O}$ presente estudo está avaliando um projeto de 30 anos de duração em que o grande interesse reside tanto em uma análise da realocação de fatores da economia, quanto na distribuição geográfica de indicadores econômicos, provocados pela alteração das fontes de recursos financiadores de determinada obra de investimento em infraestrutura rodoviária. Desta forma, para captar o efeito desejado, focar-se-á no fechamento de longo prazo, que permite a realocação de capital e trabalho tanto no espaço quanto entre os distintos setores da economia.

Na próxima seção apresenta-se como o modelo IEGC é estruturado para avaliar o problema proposto por este trabalho assim como os principais resultados encontrados pelas simulações. A seção se inicia apresentando o estudo de caso que será avaliado. 


\section{SIMULAÇÃO E RESULTADOS}

Para avaliar os diferentes impactos de uma intervenção rodoviária financiada pela cobrança de pedágio vis-à-vis seu financiamento por meio de uma expansão na alíquota de impostos, será estudado o caso de um trecho da BR-040, com extensão de 936,8 quilômetros que liga Brasília (DF) a Juiz de Fora (MG) passando pela capital mineira e que foi recentemente concedida à iniciativa privada na Fase Um da Terceira Etapa do Programa Federal de Concessões Rodoviárias. Serão simulados três cenários: (i) um em que, assim como na concessão, os custos são arcados pelo usuário mediante a cobrança de uma tarifa de pedágio; (ii) outro em que os custos da rodovia são pagos pelo Governo Federal mediante arrecadação via imposto sobre os salários; e (iii) outro em que os custos também são pagos pelo governo, porém, mediante a expansão da alíquota de imposto sobre as vendas do setor de transportes. Além disso, para avaliar o impacto da simples redução dos custos de transportes, ignorando seu financiamento, outro cenário será simulado (cenário 0).

A primeira etapa desta seção apresenta a rodovia BR-040, objeto de estudo das simulações, destacando informações relativas à sua concessão. Em seguida, apresenta-se a estrutura das simulações, mostrando como cada um dos cenários foi construído no âmbito do modelo que será utilizado. Por fim, apresentam-se e discutem-se os resultados encontrados.

\subsection{Objeto de estudo, a Rodovia BR-040}

Os trechos da BR-040 que foram concedidos nesta última rodada de concessões são classificados em três tipos: pista simples, pista dupla e pista em multifaixas. Os trechos deste último tipo são aqueles com mais de uma pista em cada sentido, porém, que não atendem aos padrões mínimos de qualidade de uma pista dupla, não possuindo separação central ou acostamento. Dentre as obrigações contratadas, a concessionária deverá duplicar 557,2 quilômetros de rodovias, que hoje se encontram com pista simples, e fazer melhorias em outros 157,3 quilômetros de multifaixas (Programa de Exploração de Rodovias ${ }^{20}$ ). A Figura 8, a seguir, mostra os trechos da rodovia que serão duplicados (verde) e aqueles que serão adequados aos padrões de pista dupla (azul).

\footnotetext{
${ }^{20}$ Programa de Exploração da Rodovia é o Anexo II do edital de concessão da rodovia BR-040 (BRASIL, 2013).
} 


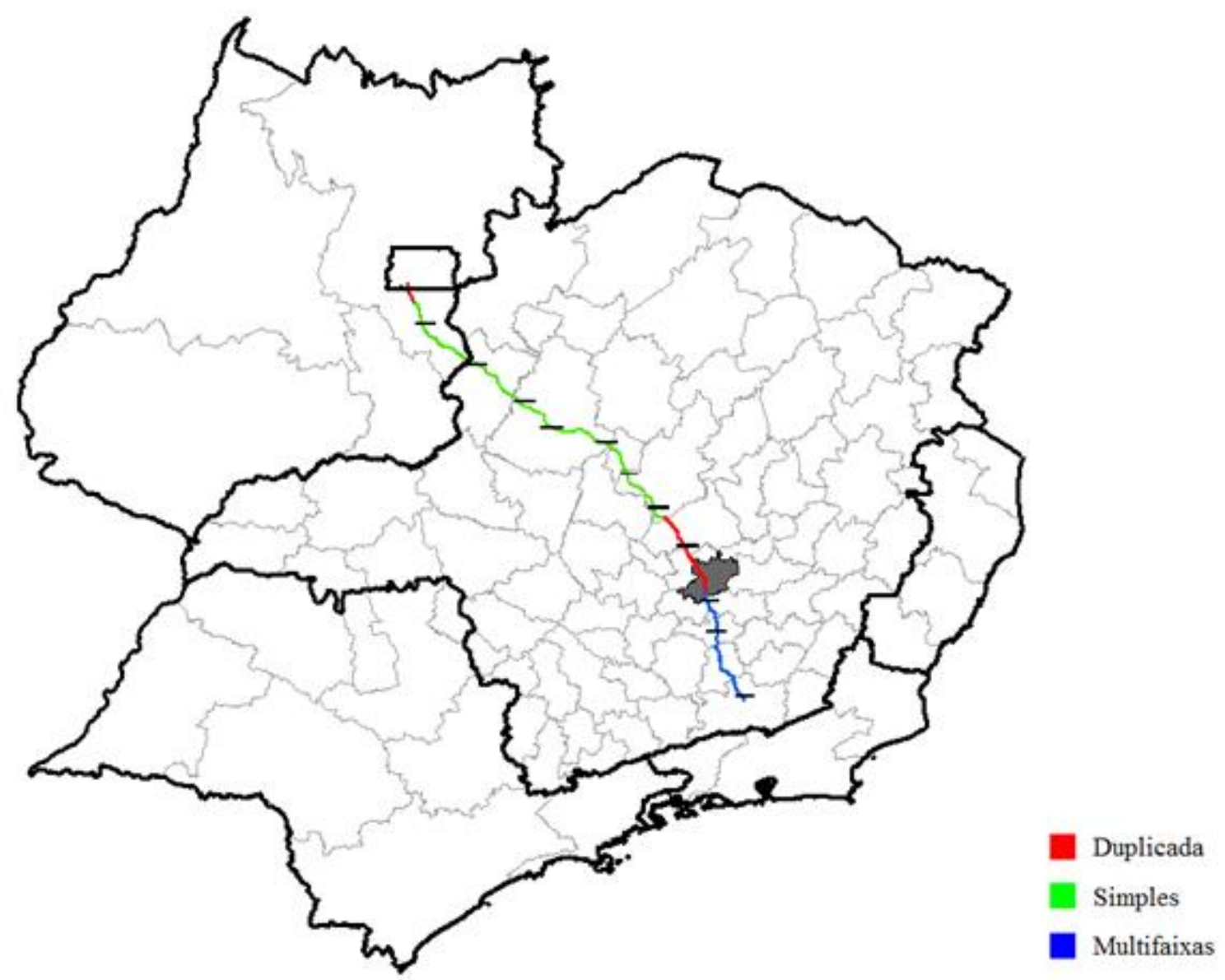

Figura 8 - Localização da rodovia BR-040 com as praças de pedágio e Belo Horizonte em destaque

Fonte: Elaboração própria com informações do Programa de Exploração da Rodovia ${ }^{21}$

A Tabela 4, a seguir, apresenta cada um dos trechos da rodovia concedida, apontando qual a sua extensão, a estimativa de sua velocidade antes da concessão, sua classificação conforme critérios apresentados anteriormente e a indicação de quais trechos possuem praça de pedágio.

\footnotetext{
${ }^{21}$ Informações contidas no apêndice B do Programa de Exploração da Rodovia (BRASIL, 2013).
} 
Tabela 4 - Trechos da Rodovia BR-040 entre Brasília (DF) e Juiz de Fora (MG)

\begin{tabular}{|c|c|c|c|c|}
\hline Código & Pedágios & $\begin{array}{c}\text { Extensão } \\
{[\mathrm{km}]}\end{array}$ & $\begin{array}{c}\text { Velocidade } \\
\text { inicial }[\mathrm{km} / \mathrm{h}]\end{array}$ & Pista \\
\hline 040BDF0010 & 0 & 2,2 & 75 & DUP \\
\hline 040BDF0012 & 0 & 2,8 & 75 & DUP \\
\hline 040BDF0015 & 0 & 0,6 & 75 & DUP \\
\hline 040BDF0017 & 0 & 2,6 & 75 & DUP \\
\hline 040BDF0020 & 0 & 0,2 & 75 & DUP \\
\hline 040BGO0030 & 0 & 24,1 & 75 & DUP \\
\hline 040BGO0050 & 0 & 71,6 & 65 & PAV \\
\hline 040BGO0070 & 1 & 61,6 & 65 & PAV \\
\hline 040BMG0090 & 1 & 40,7 & 65 & PAV \\
\hline 040BMG0093 & 0 & 3,4 & 65 & PAV \\
\hline 040BMG0097 & 0 & 6,5 & 65 & PAV \\
\hline 040BMG0100 & 0 & 17,9 & 65 & PAV \\
\hline 040BMG0110 & 0 & 19,3 & 65 & PAV \\
\hline 040BMG0120 & 1 & 31,1 & 65 & PAV \\
\hline 040BMG0130 & 0 & 26,3 & 65 & PAV \\
\hline 040BMG0150 & 1 & 79,5 & 65 & PAV \\
\hline 040BMG0170 & 1 & 61 & 65 & PAV \\
\hline 040BMG0190 & 0 & 25,2 & 65 & PAV \\
\hline 040BMG0195 & 1 & 28,8 & 65 & PAV \\
\hline 040BMG0200 & 0 & 21 & 65 & PAV \\
\hline 040BMG0210 & 0 & 24,2 & 65 & PAV \\
\hline 040BMG0217 & 1 & 28,9 & 65 & PAV \\
\hline 040BMG0230 & 0 & 9,9 & 65 & PAV \\
\hline 040BMG0250 & 0 & 19,6 & 65 & PAV \\
\hline 040BMG0262 & 0 & 2,7 & 75 & DUP \\
\hline 040BMG0266 & 0 & 2 & 65 & PAV \\
\hline 040BMG0270 & 0 & 23,2 & 65 & PAV \\
\hline 040BMG0290 & 0 & 2 & 75 & DUP \\
\hline 040BMG0330 & 1 & 35,4 & 75 & DUP \\
\hline 040BMG0350 & 0 & 16,6 & 75 & DUP \\
\hline 040BMG0360 & 0 & 7,6 & 75 & DUP \\
\hline 040BMG0370 & 0 & 2,6 & 75 & DUP \\
\hline 040BMG0390 & 0 & 8,2 & 75 & DUP \\
\hline 040BMG0400 & 0 & 19,6 & 75 & DUP \\
\hline 040BMG0410 & 1 & 34,3 & 70 & MULT \\
\hline 040BMG0430 & 0 & 13,9 & 70 & MULT \\
\hline 040BMG0450 & 0 & 3,9 & 65 & MULT \\
\hline 040BMG0457 & 0 & 1,8 & 65 & MULT \\
\hline 040BMG0470 & 0 & 12,1 & 70 & MULT \\
\hline 040BMG0490 & 1 & 37,8 & 70 & MULT \\
\hline 040BMG0510 & 0 & 33,2 & 65 & MULT \\
\hline 040BMG0530 & 0 & 15,9 & 70 & MULT \\
\hline 040BMG0550 & 0 & 17,4 & 70 & MULT \\
\hline 040BMG0565 & 1 & 11,3 & 70 & MULT \\
\hline 040BMG0570 & 0 & 27,9 & 70 & MULT \\
\hline
\end{tabular}

Fonte: Elaboração própria com informações do Programa de Exploração da Rodovia ${ }^{22}$

${ }^{22}$ Apêndice B do Programa de Exploração da Rodovia (BRASIL, 2013). 
Para realizar todos os investimentos exigidos no contrato, além de arcar com os custos de operação e manutenção, a tarifa básica de pedágio estimada pela Estruturadora Brasileira de Projetos (EBP), considerando a demanda de cada tipo de veículo, foi de $\mathrm{R} \$ 4,41$ (data-base: 2002). Porém, assim como em outras etapas do programa federal de concessões, o leilão foi feito com base na menor tarifa proposta pelo proponente, e a empresa vencedora foi a Invepar apresentando um deságio de $61,13 \%$, de forma que a tarifa base de pedágio passou para o valor de R\$1,72 (data-base: 2002$)^{23}$

A concessionária Invepar foi criada em 2000 para assumir a concessão da via expressa Linha Amarela no Rio de Janeiro e de uma rodovia no litoral norte na Bahia, a BA-099. A empresa é formada por 14 concessionárias de serviços públicos nas áreas de rodovias, aeroportos e mobilidade urbana. Entre os acionistas da Invepar, a OAS S.A. é uma empresa de capital privado focada na construção e investimentos em obras de infraestrutura. Os outros acionistas são os três maiores fundos de pensão atuando no mercado nacional (FUNCEF, PETROS e PREVI). A Invepar é uma das maiores empresas concessionárias no país, administrando mais de $1.900 \mathrm{~km}$ de rodovia, além de serviços metroviários e o aeroporto internacional de Guarulhos. Na Figura 9, segue a estrutura acionária do grupo, assim como as empresas por ele administradas (INVEPAR, 2013).

\footnotetext{
${ }^{23} \mathrm{Na}$ licitação, os valores são todos de 2012, assim, o valor máximo de edital e a proposta feita pelo licitante vencedor são, respectivamente, $\mathrm{R}$ \$ 8,29 e R \$ 3,23. Como o modelo sendo utilizado está na data-base de 2002, os valores das tarifas foram deflacionados pelo IPCA.
} 


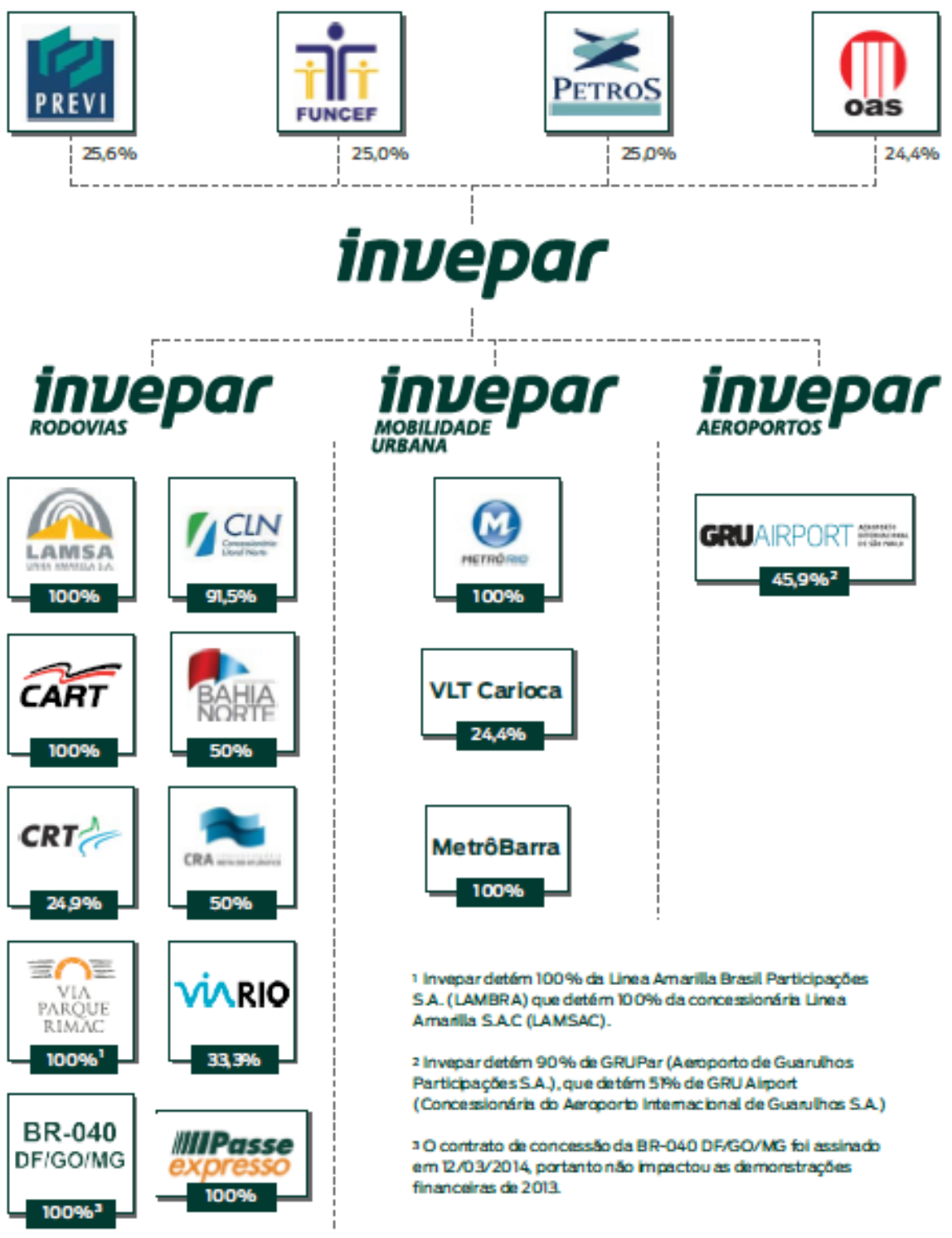

Figura 9 - Estrutura acionária e controladas da Invepar em 2013

Fonte: Invepar (2013)

\subsection{Estrutura da simulação}

Conforme salientado na Seção 3.1.1.3, o choque no modelo de equilíbrio geral é a variação nos custos de transporte entre os pares de origem-destino (O-D), que é traduzido em variação da variável AMARG_I do modelo IEGC. Tais custos são calculados com o auxílio de um modelo de transportes integrado sequencialmente ao modelo de equilíbrio geral. Nesse 
trabalho, o software Transcad ${ }^{24} 4.5$ será alimentado com a rede rodoviária do PNLT - Plano Nacional de Logística e Transportes (BRASIL, 2010) e, baseado num processo de otimização de trajetos, calculará qual o tempo mínimo de viagem entre cada par O-D. ${ }^{25}$ Como em Haddad (2004), para o transporte intra-regional, considera-se que a distância percorrida para qualquer transação equivale à metade do raio implícito relativo à área da região. ${ }^{26}$ Para encontrar o tempo de se percorrer esta distância, utiliza-se a velocidade média das rodovias da região. Para que a variação observada possa ser transformada em um choque exógeno a ser aplicado ao modelo de equilíbrio geral, a matriz de tempos mínimos deve ser criada para um período antes e um período depois dos investimentos.

Para gerar o choque na variável AMARG_I do modelo de equilíbrio geral, as variações nos tempos de viagem devem ser convertidas em variações de custos. Uma função de custos foi estimada com base em dados do PNLT de 2011. A base traz informações sobre o fluxo de comércio para diversos produtos e modais de transporte entre pares de O-D. As principais variáveis são:

- Região de origem das mercadorias;

- Região de destino;

- Tempo de viagem;

- Custo da transação;

- Volume;

- Modal de transporte;

- Tipo de produto.

Como neste trabalho o interesse reside exclusivamente no transporte rodoviário, as observações relativas aos outros modais foram descartadas. Além disso, os custos foram todos corrigidos pelo IPCA para o ano de 2002, uma vez que esta é a data de calibragem do modelo

\footnotetext{
${ }^{24}$ Software desenvolvido pela empresa americana Caliper especializada em tecnologia georreferenciada e software de transporte.

${ }^{25}$ A malha rodoviária inteira é dividida em mais de 18 mil trechos homogêneos que contêm informações sobre sua extensão e velocidade, sendo possível calcular o tempo de deslocamento em cada trecho. Dado um par de O$\mathrm{D}$, o software seleciona o conjunto de trechos que minimizam o tempo de viagem entre eles.

${ }^{26}$ Raio implícito de uma região é aquele que forma uma circunferência com a mesma área da região em análise.
} 
de equilíbrio geral. Tendo o tempo de viagem como argumento, estimou-se uma função loglog de custos (modelo de elasticidade constante), obtendo-se a fórmula abaixo:

$$
\widehat{\ln \left(c_{O D}\right)}=2,47+0,62 * \ln \left(t_{O D}\right)
$$

onde $c_{O D}$ e $t_{O D}$ representam, respectivamente, o custo e o tempo de viagem entre os pares de O-D. ${ }^{27}$ Os coeficientes estimados mostram que, em média, o aumento em $1 \%$ no tempo de viagem leva a um aumento de $0,62 \%$ nos custos.

Aplicou-se essa função nas matrizes de tempos mínimos calculada pelo TransCad antes e depois da intervenção na rodovia e a diferença percentual entre elas representa o choque exógeno nos custos de transporte (na variável AMARG_I). A intervenção na rodovia deve considerar a situação com e sem pedágio, e, para tanto, foram construídos três cenários de simulação. O cenário 1 é aquele que considera a existência de praças de pedágio para financiar os investimentos, operação e a manutenção da rodovia. Nos cenários 2 e 3, todo investimento, manutenção e operação são financiados pelo Poder Público por meio de tributos e contribuições de toda a sociedade, sendo que, no cenário 2, utiliza-se um incremento do imposto sobre os salários dos trabalhadores e, no 3, um imposto sobre as vendas do setor de transportes. A Figura 10, a seguir, ilustra como cada cenário foi construído.

Inicialmente, foi necessário transformar a velocidade e extensão de cada trecho em tempo de deslocamento, o qual, por meio do modelo de transportes gera uma matriz de tempo mínimo entre cada par O-D. Aplicando a função log-log estimada anteriormente (equação 6) em cada célula da matriz, tem-se nova matriz que representa o custo mínimo para o deslocamento entre os pares O-D. Este constitui o cenário base que representa o equilíbrio vigente do sistema. ${ }^{28}$

\footnotetext{
${ }^{27}$ Foram também estimadas outras três formas funcionais, a saber, uma função linear, uma log linear e uma quadrática. A função log-log utilizada foi aquela que apresentou o melhor ajuste (maior valor de R quadrado ajustado), com ambos coeficientes sendo significativos à $1 \%$.

${ }^{28}$ As margens de transporte devem estar inicialmente calibradas de forma a representar esta matriz de custos de transportes inicial.
} 


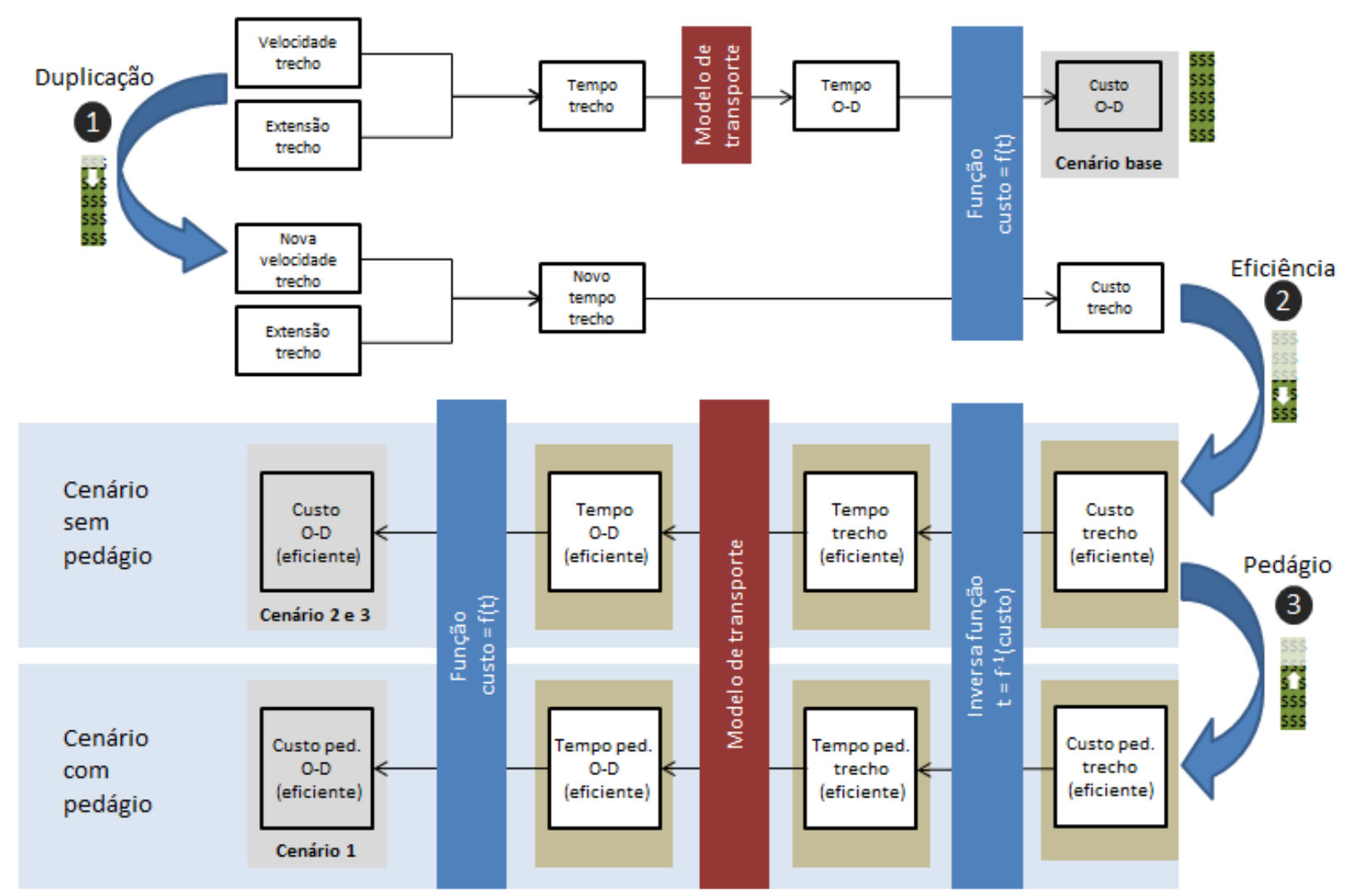

Figura 10 - Variação nos custos de transporte

Fonte: Elaboração própria

O primeiro passo para a construção dos cenários de comparação é aplicar a intervenção nos trechos com previsão de duplicação pelo contrato de concessão. Os trechos previstos para duplicação aparecem na base do PNLT com velocidade próxima a $60 \mathrm{~km} / \mathrm{h}$, enquanto nos trechos já duplicados da BR-040, tal velocidade é de cerca de $75 \mathrm{~km} / \mathrm{h}$. Assim, para avaliar os efeitos das intervenções construtivas na rodovia, igualou-se a velocidade de todos trechos pertencentes à rodovia ao seu valor teto de $75 \mathrm{~km} / \mathrm{h}$ (intervenção indicada pelo número 1 na Figura 10). Com a nova velocidade, calculou-se um novo tempo de deslocamento por trechos e, utilizando a função de custo, calculou-se o custo desse deslocamento para cada trecho. $\mathrm{O}$ efeito dessa intervenção no custo de se trafegar pela BR-040 atinge de forma heterogênea a matriz de custos mínimos, uma vez que nem todas as rotas de O-D usufruem dos benefícios da duplicação.

O segundo passo para gerar os cenários de interesse (indicado pelo número 2 na Figura 10) refere-se à maior eficiência permitida por uma rodovia em melhores condições de rodagem. 
Dados da Pesquisa CNT de Rodovias 2014 (CNT, 2014) dividem a malha brasileira em cinco classificações de qualidade, a saber, ótimo, bom, regular, ruim e péssimo. Esse estudo aponta que à medida que a qualidade da pavimentação vai caindo nessa graduação, maior é o custo de transporte (relativamente ao nível ótimo). A coluna "Incremento de custo" da Tabela 5 abaixo aponta qual o incremento de custo estimado para cada tipo de qualidade do pavimento.

Tabela 5 - Incremento de custo de rodagem por tipo de rodovia

\begin{tabular}{|l|c|c|c|}
\cline { 3 - 4 } \multicolumn{2}{c|}{} & \multicolumn{2}{c|}{ Tipo de rodovia } \\
\hline Ótimo & $\begin{array}{c}\text { Incremento } \\
\text { custo }\end{array}$ & Concedida & Pública \\
\hline Bom & $0 \%$ & $71 \%$ & $36 \%$ \\
\hline Regular & $19 \%$ & $9 \%$ & $8 \%$ \\
\hline Ruim & $61 \%$ & $17 \%$ & $41 \%$ \\
\hline Péssimo & $96 \%$ & $3 \%$ & $12 \%$ \\
\hline \multicolumn{2}{|c|}{$\begin{array}{r}\text { Soma ponderada do } \\
\text { incremento de custo por } \\
\text { tipo de rodovia }\end{array}$} & $11 \%$ & $\mathbf{3 0} \%$ \\
\hline \multicolumn{2}{|r|}{} & $1 \%$ & $4 \%$ \\
\hline
\end{tabular}

Fonte: Elaboração própria com dados de CNT (2014)

Além do incremento estimado de custo em relação à qualidade do pavimento, as duas colunas da direita da tabela (Tabela 5) demonstram qual a porcentagem das rodovias concedidas e públicas que se enquadram em cada classificação. Fazendo a soma do incremento de preço ponderado pela proporção de cada classificação por tipo de rodovia, estima-se que o sobrepreço médio em relação às rodovias ótimas de uma rodovia concedida é de cerca de $11 \%$, enquanto nas rodovias públicas, esse valor é de 30\%. Assim, trabalha-se com a hipótese de que, ao atribuir as responsabilidades de reparos, operação e manutenção de uma rodovia pública a um parceiro privado, seu custo de se transitar pela rodovia irá experimentar uma queda de cerca de $15 \% .{ }^{29}$ Vale ressaltar que esse ganho de eficiência é homogêneo ao longo

\footnotetext{
${ }^{29}$ O custo, inicialmente, é de $130 \%$ do custo das rodovias ótimas passando a $111 \%$ após a intervenção, o que representa um incremento de eficiência de cerca de $15 \%$.
} 
de toda rodovia sendo concedida, uma vez que não estão sendo feitas distinções de ganhos de eficiência específicos por trecho.

Por meio da inversa da função de custos, calculou-se o novo tempo de deslocamento por trecho (considerando os ganhos de eficiência) e, utilizando o modelo de transporte, calculouse uma nova matriz de tempos mínimos a partir da qual foi possível obter os custos de transportes entre O-D que irão compor os cenários dois e três. Ainda para a construção desses cenários, foi preciso calcular o montante a ser arrecadado anualmente pelo governo (seja com impostos sobre salários seja com imposto sobre as vendas no setor de transportes) para cobrir os custos da rodovia. Para tanto, utilizou-se a estimativa de demanda da EBP (2013) ao longo dos 30 anos de concessão e o valor da tarifa base a preços de 2002 para calcular a arrecadação tarifária estimada durante toda a vigência do contrato. Essa arrecadação cresce ao longo do tempo acompanhando o crescimento da demanda, porém, para simular um cenário de equilíbrio no longo prazo, foi preciso encontrar um valor de arrecadação constante no tempo. Para se calcular esse valor, encontrou-se uma arrecadação constante que resultasse no mesmo valor presente líquido da arrecadação calculada com os dados da EBP para um taxa de retorno de 7,2\% (valor referencial da Taxa Interna de Retorno utilizado na modelagem do projeto). Por essa metodologia, o valor uniforme que o governo deverá arrecadar para arcar com os custos do projeto ao longo dos 30 anos é de R 143 milhões por ano. Ainda, nos cenários 2 e 3, fixou-se o consumo do governo nos níveis pós investimento (cenário 0 a ser explicado abaixo), para garantir que esses recursos arrecadados com os impostos não serão utilizados para o consumo governamental, mas sim, para os investimentos na rodovia.

Para calcular o cenário 1 foi necessário realizar mais um passo (indicado pelo número 3 na Figura 10) que considerasse o preço de cada praça de pedágio nos custos de transportes. Para fins de simulação, foram considerados pedágios temporais, ou seja, é como se o motorista atravessando uma praça precisasse parado nela por um tempo. Esse tempo perdido terá o mesmo custo ao motorista que o valor da tarifa de pedágio por ele devida. A cada trecho homogêneo pedagiado, adicionou-se o preço equivalente de sua praça (preço que considera o número de eixos e peso médio dos veículos que transitam por cada praça, a valores de 2002) aos custos de deslocamento inicialmente estimados. Em seguida, calculou-se novamente, por meio da inversa da função de custo, o tempo de deslocamento por trecho e, por meio do modelo de transportes, o tempo mínimo de viagem entre os pares O-D, de onde se encontra o custo de deslocamento entre pares O-D. A inserção dos pedágios apenas nos trechos 
pedagiados gerou impacto heterogêneo ao longo da rodovia, uma vez que diferentes rotas trafegam por diferentes quantidades de praças de pedágio.

Além dos três cenários descritos, a título de comparação, será simulado um cenário inicial (doravante cenário 0) em que são aplicados apenas os choques nos custos de transporte, desconsiderando o valor das praças de pedágio e um incremento nas alíquotas tributárias, ou seja, neste cenário desconsidera-se a remuneração e o financiamento dos investimentos, da operação e da manutenção. Assim, os cenários simulados que serão comparados ao equilíbrio inicial são descritos na Tabela 6.

Tabela 6 - Cenários de simulação

\begin{tabular}{|l|l|}
\hline CENÁRIO & ESTRUTURA DA SIMULAÇÃO \\
\hline Cenário 0 & Choque nos custos de transporte sem considerar seus custos. \\
\hline Cenário 1 & Choque nos custos de transporte considerando o preço das praças de pedágio. \\
\hline Cenário 2 & $\begin{array}{l}\text { Choque nos custos de transporte sem custo de pedágio + choque no valor do } \\
\text { imposto de renda pago pelas famílias. }\end{array}$ \\
\hline Cenário 3 & $\begin{array}{l}\text { Choque nos custos de transporte sem custo de pedágio + choque no imposto } \\
\text { sobre as vendas do setor de transportes. }\end{array}$ \\
\hline
\end{tabular}

Fonte: Elaboração própria

\subsection{Resultados}

Esta seção apresenta os resultados das simulações, comparando as diferentes alternativas de financiamento dos investimentos na BR-040. ${ }^{30}$ Inicialmente, discute-se a relação causal entre as variáveis do modelo, em seguida são apresentados os resultados agregados e regionalizados das simulações. Por fim, avaliam-se as características de cada região que tornam seu PIB mais sensível a variações nos custos de transportes.

\footnotetext{
${ }^{30}$ Os quatro cenários sugeridos foram simulados com o software GEMPACK.
} 


\subsubsection{Relações advindas da estrutura teórica do modelo}

Os modelos de equilíbrio geral buscam captar não apenas a relação direta entre as variáveis, mas também os efeitos indiretos que os choques exógenos causam no sistema. A Figura 11 a seguir apresenta de que forma a variação no custo de transporte se propaga entre as diferentes variáveis do modelo. Tal análise é importante para compreender os efeitos observados nos resultados das simulações.

Uma vez que no modelo utilizado o custo de determinado bem é igual à soma de seu custo básico de produção incluindo tributos que deve pagar e o custo de seu deslocamento entre a região produtora e a consumidora, um choque de eficiência nos transporte reduz o preço tanto dos bens de consumo finais quanto dos insumos intermediários. Por outro lado, com mais eficiência, o setor de transporte precisa de menos insumos para transportar a mesma quantidade de bens, o que libera fatores primários para a economia, reduzindo seu custo, o que também gera uma redução no custo dos bens e serviços da região.

A redução de preço dos bens gera pressões para expandir a exportação e diminuir as importações, além de aumentar a demanda interna. A expansão da demanda interna e das exportações estimula a produção, o que aumenta a demanda por fatores primários e por bens intermediários, gerando pressões para aumentar o preço dos bens e serviços. 


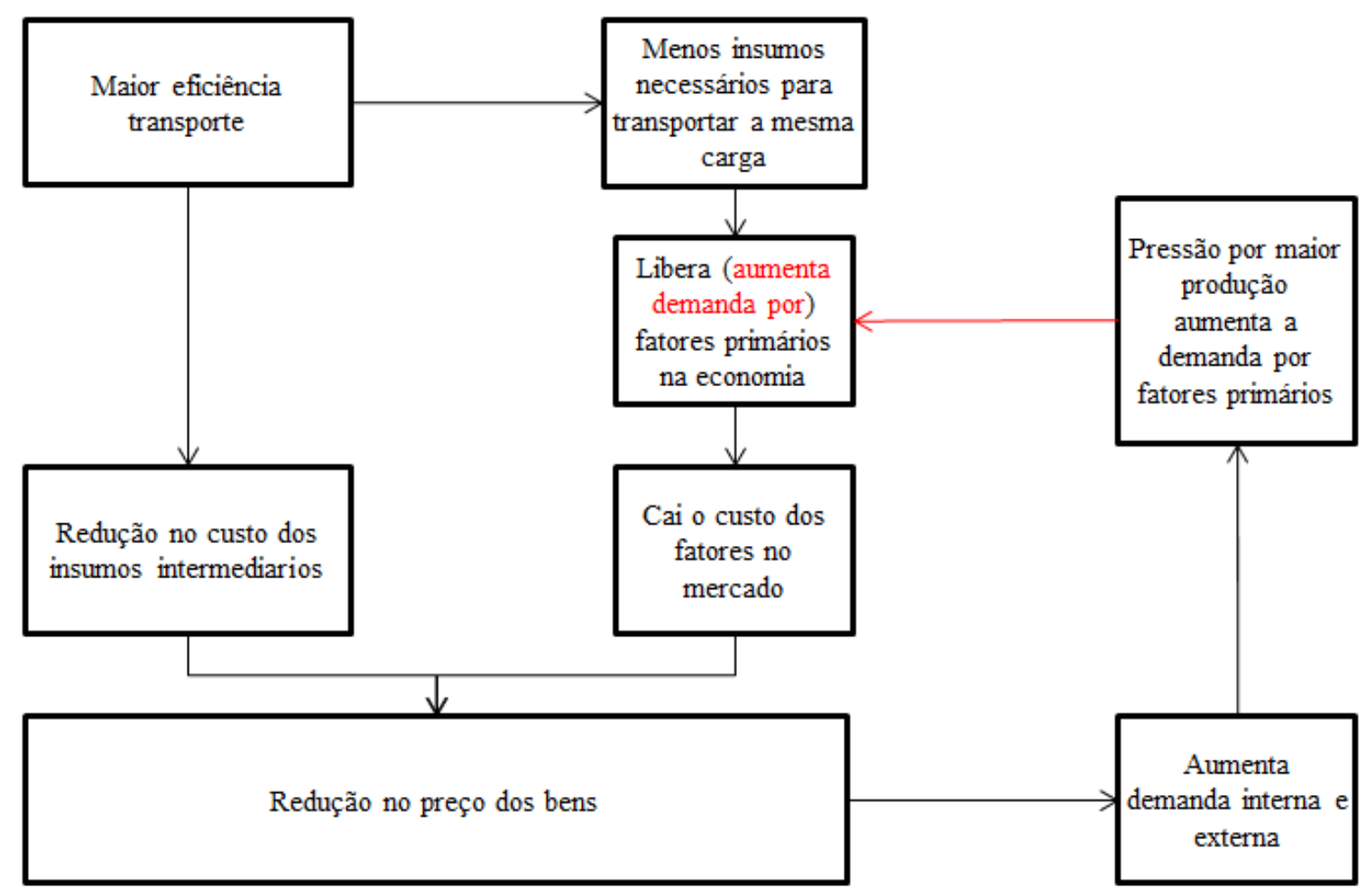

Figura 11 - Relações causais entre variáveis do modelo

Fonte: Elaboração própria

Este é o encadeamento básico do modelo pelo qual o custo de transporte afeta o estado de equilíbrio da economia. O efeito líquido desse choque exógeno será determinado pela intensidade relativa dessas forças opostas, que é determinada pelas informações contidas no modelo. A seguir apresentam-se os resultados encontrados para as variáveis agregadas da economia.

\subsubsection{Resultados agregados}

As melhorias da rodovia BR-040 têm, em geral, um efeito positivo para a economia. Como era de se esperar, o melhor cenário é aquele em que a forma de financiamento é desconsiderada (cenário 0), o que pode ser observado na Tabela 7, a seguir. Neste caso, o PIB do país experimenta um crescimento $0,014 \%$. Considerando qualquer forma de financiamento dos investimentos, o crescimento do PIB é atenuado, sendo que a inserção do pedágio (cenário 1) é levemente melhor que a expansão da alíquota de imposto sobre os salários 
(cenário 2). A superioridade do cenário 1 em relação ao cenário 2, pode ser comparável aos achados de Kim et al. (2011), uma vez que os autores concluíram, conforme discutido na seção 2.4, que o maior impacto na renda do país surge de uma cobrança localizada dos investimentos em rodovias, desonerando as outras regiões do país dos custos de tal investimento.

No caso de melhorias rodoviárias serem financiadas por imposto sobre o setor de transportes (cenário 3), o impacto no PIB torna-se negativo, fazendo deste o pior cenário sugerido, o que vai em linha com o achado de Boccanfuso et al. (2014), que avaliaram que o financiamento de infraestrutura por meio de um imposto sobre as firmas não era uma boa alternativa para estimular a economia.

Tabela 7 - Impacto nas variáveis macroeconômicas

\begin{tabular}{l|cccc} 
Variável & Cenário 0 & Cenário 1 & Cenário 2 & Cenário 3 \\
\hline PIB real [Variação \%] & 0,01451 & 0,01286 & 0,01221 & $-0,03638$ \\
$\quad$ PIB real - Minas Gerais [Variação \%] & 0,04775 & 0,03100 & 0,01874 & $-0,06673$ \\
Variação Equivalente [R\$] & 81 & 24 & 15 & -2150 \\
Emprego nacional [Variação \%] & 0,00594 & 0,00667 & 0,00495 & $-0,01234$ \\
Consumo real das familias [Variação \%] & 0,00773 & 0,00657 & 0,00099 & $-0,06591$ \\
Investimento agregado [Variação \%] & 0,01255 & 0,01043 & 0,00649 & $-0,03258$ \\
Volume de exportação [Variação \%] & 0,00305 & 0,00370 & $-0,00427$ & $-0,06054$ \\
Volume de importação [Variação \%] & 0,00172 & 0,00219 & $-0,00302$ & $-0,04245$ \\
Termos de troca da economia [Variação \%] & $-0,00076$ & $-0,00112$ & 0,00188 & 0,01927 \\
\hline \hline
\end{tabular}

Fonte: Elaboração própria

O investimento, a medida de bem-estar e o consumo real das famílias seguem a mesma tendência do PIB, qual seja, o cenário 0 (em que se desconsidera o financiamento) é a melhor situação, seguido da cobrança de pedágio dos usuários da rodovia (cenário 1), após o qual aparece o financiamento por meio de um imposto sobre os salários (cenário 2) e, por último, o pior cenário é aquele em que se aumenta o imposto sobre as vendas do setor de transportes (cenário 3).

O crescimento do PIB se reflete na expansão da atividade econômica, conforme apresentado na Tabela 8. Nos dois primeiros cenários, apenas o setor de transportes passa por uma 
contração, o que é esperado, uma vez que, com maior eficiência, usa-se menos margem e, consequentemente, menos insumos, para atender uma mesma demanda de deslocamento. No cenário 2, quando se aumenta o imposto sobre os salários, a atividade da agricultura, indústria e comércio caem, porém, são parcialmente compensados pela expansão da mineração. Neste segundo cenário, o setor de transportes tem uma queda mais abrupta que nos casos anteriores, o que ajuda a explicar a queda na atividade industrial, uma vez que a indústria é a maior fornecedora do setor de transportes (mais de 60\% dos insumos do setor de transporte provêm da indústria). Já no caso do terceiro cenário, o nível de atividade econômica cai em todos os setores, com exceção da administração pública.

Tabela 8 - Nível de atividade por setor

\begin{tabular}{l|cccc}
$\begin{array}{l}\text { Nível de atividade por } \\
\text { setor [Variação \%] }\end{array}$ & Cenário 0 & Cenário 1 & Cenário 2 & Cenário 3 \\
\hline 1 Agricultura & 0,00660 & 0,00698 & $-0,00465$ & $-0,05788$ \\
2 Mineração & 0,01501 & 0,00750 & 0,01934 & $-0,12155$ \\
3 Indústria & 0,00608 & 0,00600 & $-0,00076$ & $-0,04236$ \\
4 Construção & 0,00868 & 0,00751 & 0,00280 & $-0,03834$ \\
5 Transporte & $-0,04659$ & $-0,02990$ & $-0,05428$ & $-0,19904$ \\
6 Comério & 0,00613 & 0,00654 & $-0,00112$ & $-0,06629$ \\
7 Adm. Pública & 0,05874 & 0,04633 & 0,05845 & 0,05740 \\
8 Outros Serviços & 0,00993 & 0,00984 & 0,00590 & $-0,04772$ \\
\hline Agregado & $\mathbf{0 , 0 1 5 1 8}$ & $\mathbf{0 , 0 1 3 2 4}$ & $\mathbf{0 , 0 1 0 2 9}$ & $\mathbf{- 0 , 0 3 6 8 0}$
\end{tabular}

Fonte: Elaboração própria

\subsubsection{Resultados regionalizados}

Inicialmente, é importante avaliar qual o impacto do investimento na BR-040 nos custos de transporte de cada região. Para tanto, será construído um índice que busca captar a variação no custo de transportes de uma região com relação a todas as regiões com as quais ela transaciona, ponderando pelo fluxo de transações existente em cada elo. A fórmula do índice proposto é como segue: 


$$
\Delta c_{\text {transp_reg_i }}=-\sum_{\forall j \in \text { regiões }}\left[\left(\frac{c_{\boldsymbol{i}_{j} j}^{\text {final }}-c_{\boldsymbol{i}_{-} j}^{\text {inicial }}}{c_{\boldsymbol{i}_{-} j}^{\text {inicial }}}\right) \times\left(\frac{B A S_{\boldsymbol{i}_{-} j}}{\sum_{\forall x \in \text { regiões }} B A S_{\boldsymbol{i}_{-} x}}+\frac{B A S_{\boldsymbol{i}_{-} j}}{\sum_{\forall x \in \text { regiões }} B A S_{x_{-} \boldsymbol{i}}}\right)\right]
$$

Onde: $\Delta c_{\text {transp_reg_i }}$ é o índice de variação dos custos de transporte para a região $i$; $c_{i_{-} j}^{\text {final }}$ é o custo de transporte da região $i$ para a região $j$ após a realização dos investimentos e $\mathrm{BAS}_{\mathrm{i}_{j} j}$ é a soma dos fluxos de bens e serviços da região $i$ para a região $j$. O sinal negativo na frente da fórmula faz com que, quanto maior o índice, maior a redução dos custos de transportes para a região, assim, o índice está relacionado a um incremento da eficiência setorial.

As figuras abaixo (Figura 12 e Figura 13) apresentam o impacto dos investimentos no custo de transportes sem e com a inserção de praças de pedágio.

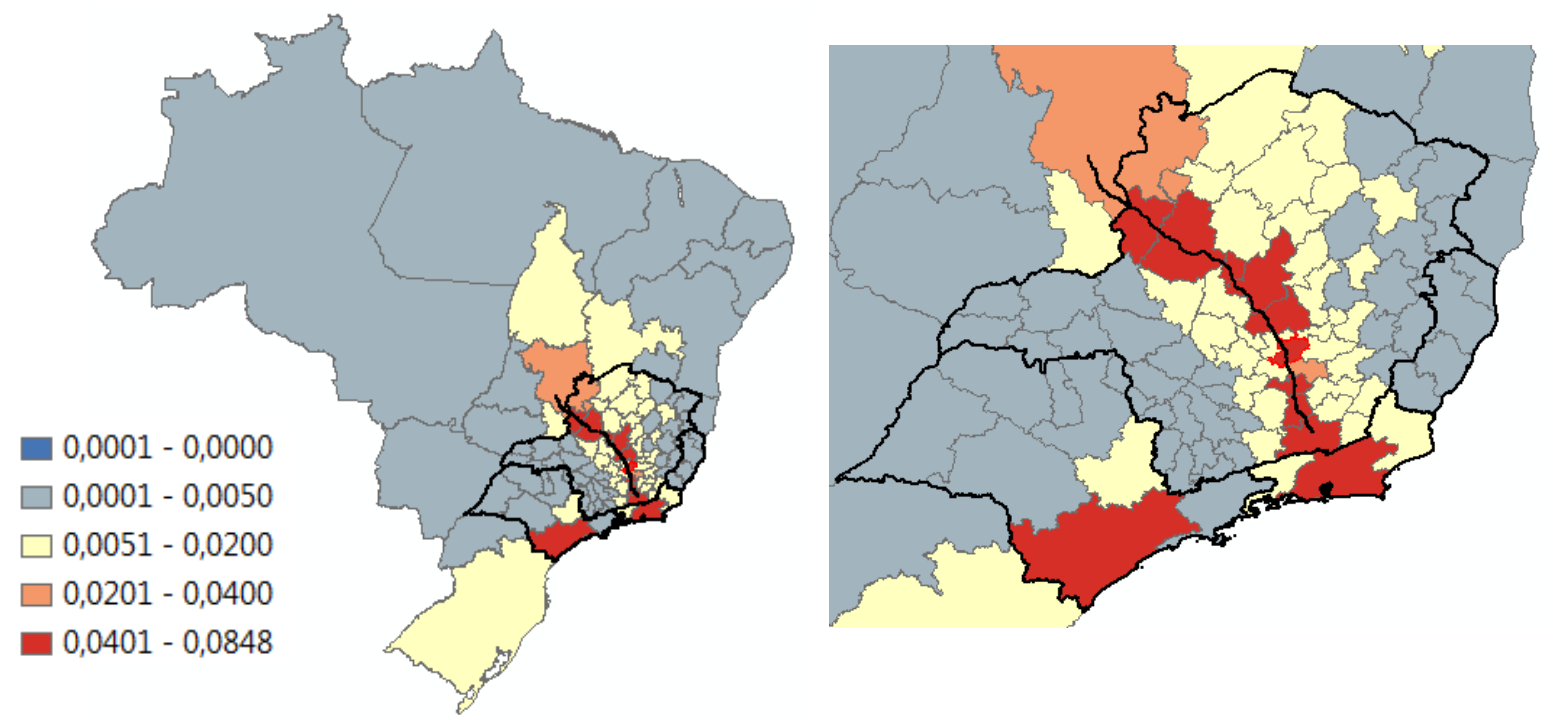

Figura 12 - Índice de variação na eficiência dos transportes sem considerar pedágio

Nota: As legendas encontram-se em variação percentual

Fonte: Elaboração própria 


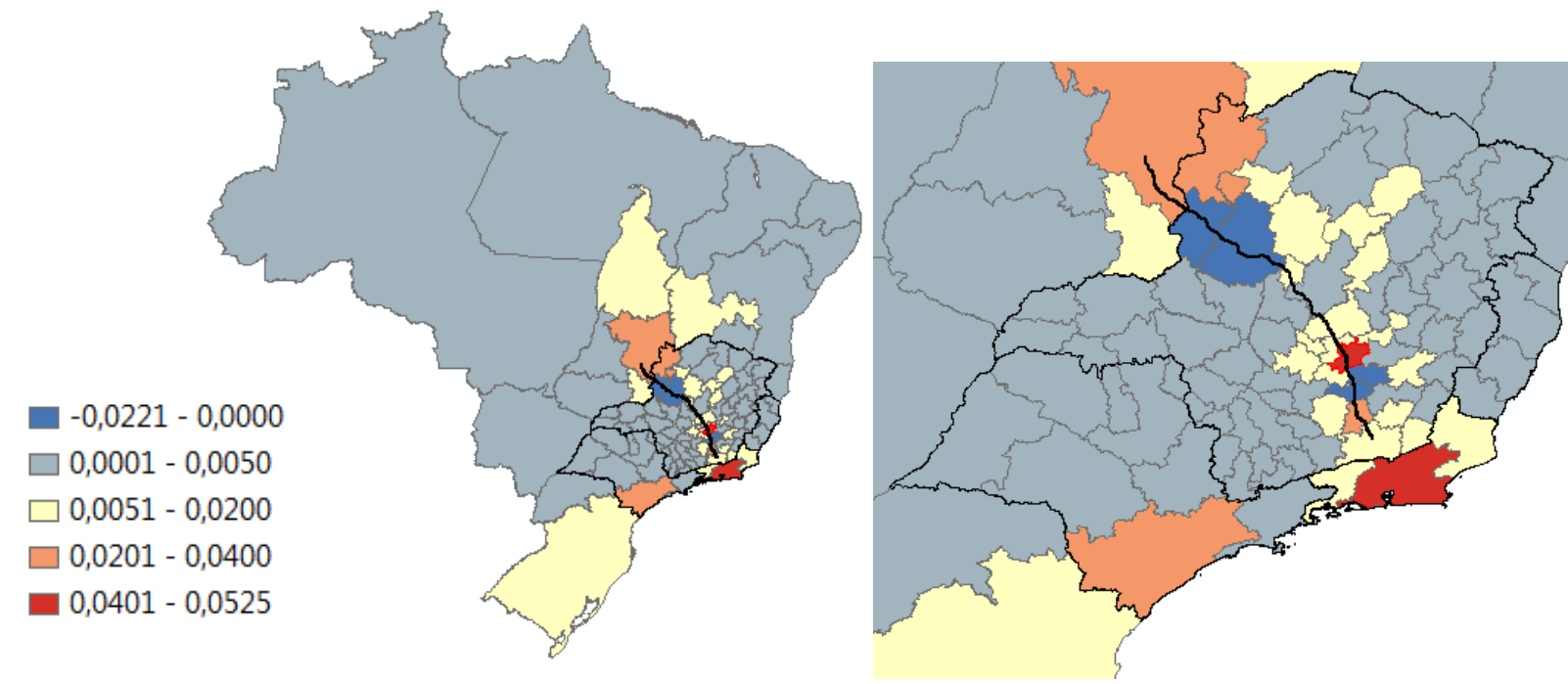

Figura 13 - Índice de variação na eficiência dos transportes considerando pedágio

Nota: As legendas encontram-se em variação percentual

Fonte: Elaboração própria

Como era de se esperar, a inserção dos pedágios tem o efeito de atenuar a redução do índice de variação dos custos de transporte e, no caso das regiões de Paracatu, João Pinheiro, Ouro Preto e Conselheiro Lafaiete, observa-se, inclusive, um aumento de tal índice, representando um maior custo de transportes advindo da inserção de pedágio. Como pode ser observado na Figura 14, uma simples melhoria na BR-040 ignorando seu financiamento (cenário 0), divide o país em: (i) uma faixa beneficiada, composta pelas regiões pertencentes ao eixo da rodovia, indo do Rio de Janeiro a Belém e passando pelo Distrito Federal e Tocantins; e (ii) regiões prejudicadas que se encontram fora dessa área de influência direta da rodovia. As regiões no eixo da rodovia são beneficiadas pelo maior acesso a grandes mercados consumidores e produtores. Isso aumenta a competitividade dessas regiões, antes menos acessíveis, com relação ao resto do Brasil, prejudicando as regiões menos atingidas pela melhoria da rodovia. Ainda, as regiões de São Paulo e Campinas, que poderiam ser beneficiadas pelos seus ganhos de escala somados ao maior acesso a mercados antes menos acessíveis, são grandes fornecedoras de insumos para o setor de transportes (responsáveis por cerca de $30 \%$ da produção desses insumos). Assim, quanto maior a eficiência do setor de transportes, menor a necessidade de utilização desse bem margem para um mesmo nível de deslocamento de mercadorias, o que diminui a demanda pelos insumos para o setor de transporte produzidos 
nas regiões de São Paulo e Campinas, impactando negativamente a atividade dessas duas regiões.

O financiamento do investimento através da criação de praças de pedágio (cenário 1) é análogo a uma redução mais amena dos custos de transporte. Neste cenário, as regiões paulistas na fronteira de MG com SP acabam sendo menos prejudicadas, pois seus produtos tornam-se, novamente, mais competitivos frente às regiões mais dependentes da rodovia BR040. Já as regiões mineiras próximas a essa fronteira passam a enfrentar maior concorrência das regiões afetadas pela estrada e observam uma redução em seu PIB. Também vale notar que, considerando a existência de praças de pedágio, a região de Brasília, que está entre as mais beneficiadas em quase todos os cenários, passa a observar um crescimento de PIB um pouco inferior (mas ainda positivo), o que é esperado uma vez que a queda nos custos de transporte é atenuada pela inserção das praças de pedágio ao longo da rodovia.

Considerar o financiamento do investimento mediante o imposto sobre a renda (cenário 2) traz um benefício ainda maior para as regiões no eixo da BR-040. Em particular, Brasília e as regiões ao seu redor, que já estavam sendo beneficiadas, agora compartilham os custos do investimento com o resto do país e acabam experimentando um crescimento econômico ainda maior. As regiões mineiras nas fronteiras com os estados de São Paulo e do Espírito Santo, que antes estavam sendo beneficiadas pelo projeto, passam a observar uma queda no PIB. Essas regiões, além de não compartilharem os benefícios da rodovia, agora devem arcar com seus custos, assim como acontece com as regiões fora do eixo da BR-040. O financiamento por meio de impostos sobre o setor de transportes é o pior cenário, em que regiões que antes eram beneficiadas passam a observar uma redução do seu PIB. 
Cenário 0

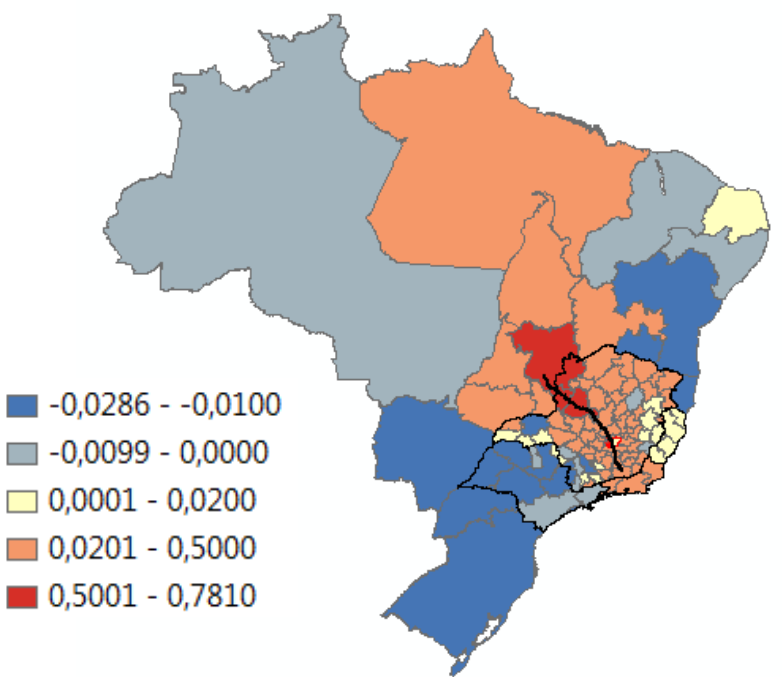

Cenário 2

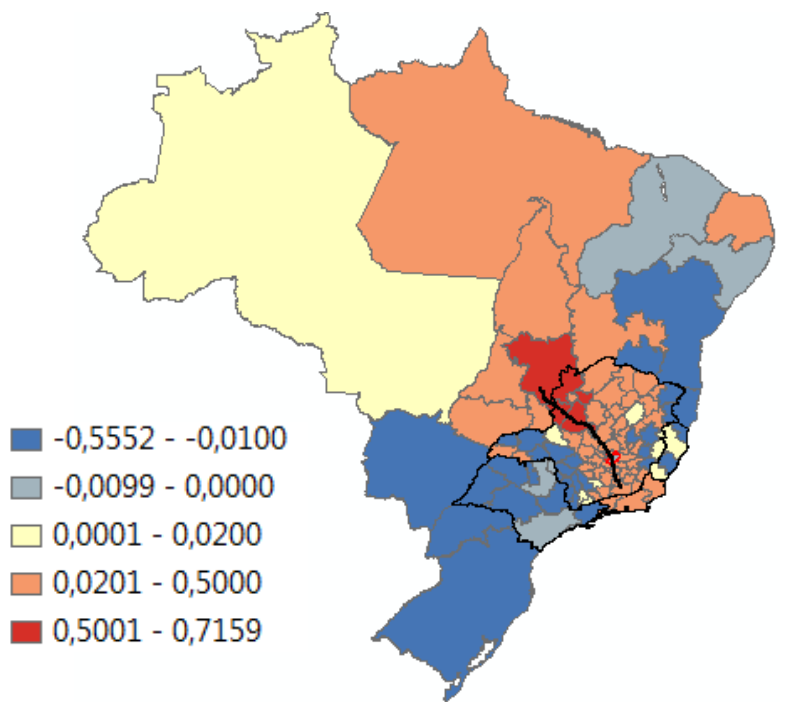

Cenário 1

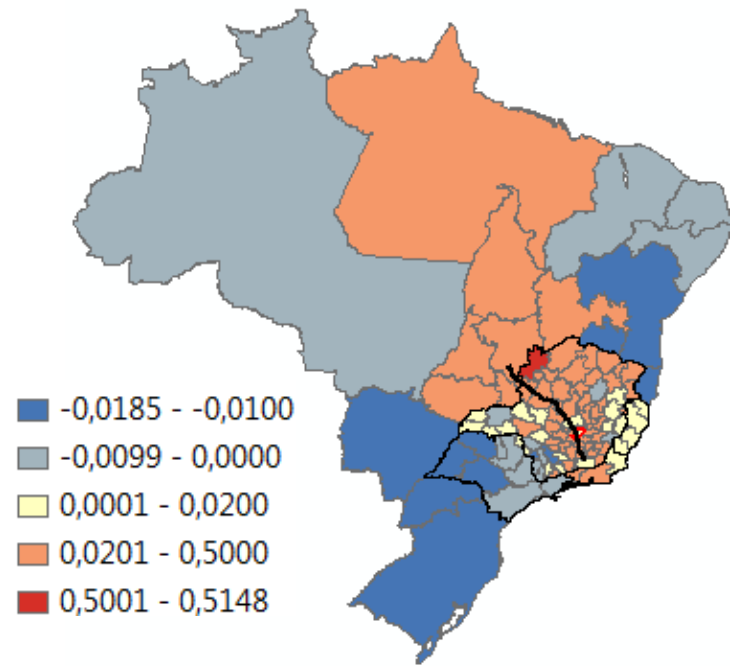

Cenário 3

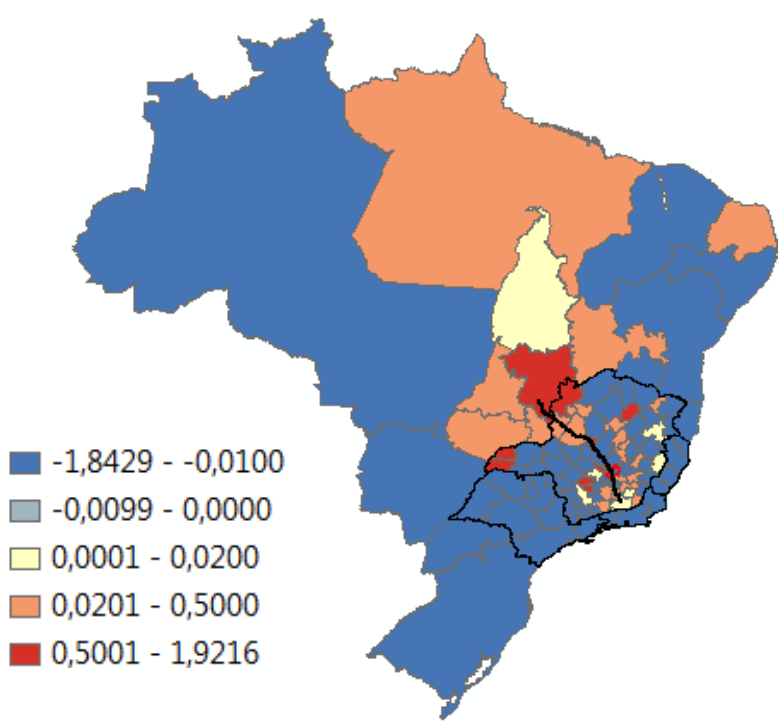

Figura 14 - Variação do PIB

Nota: As legendas encontram-se em variação percentual ${ }^{31}$

Fonte: Elaboração própria

Ao observar a Figura 15, que apresenta a distribuição dos impactos das melhorias da rodovia sobre consumo real das famílias, percebe-se um comportamento análogo ao da distribuição do

\footnotetext{
${ }^{31}$ A variação do PIB por região pode ser consultada no Apêndice A deste trabalho.
} 
PIB, com regiões beneficiadas encontrando-se na área de influência direta da rodovia BR-040 e regiões prejudicadas nos arredores desse eixo. Porém, para essa variável, existe uma maior heterogeneidade regional no interior de MG, uma vez que diversas regiões ao redor da rodovia acabam tendo o consumo de suas famílias reduzido.

\section{Cenário 0}

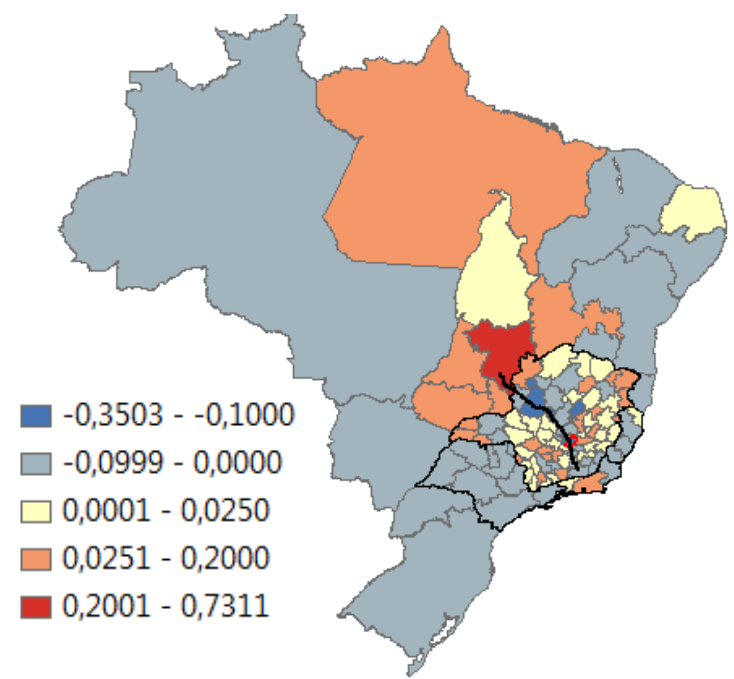

Cenário 2

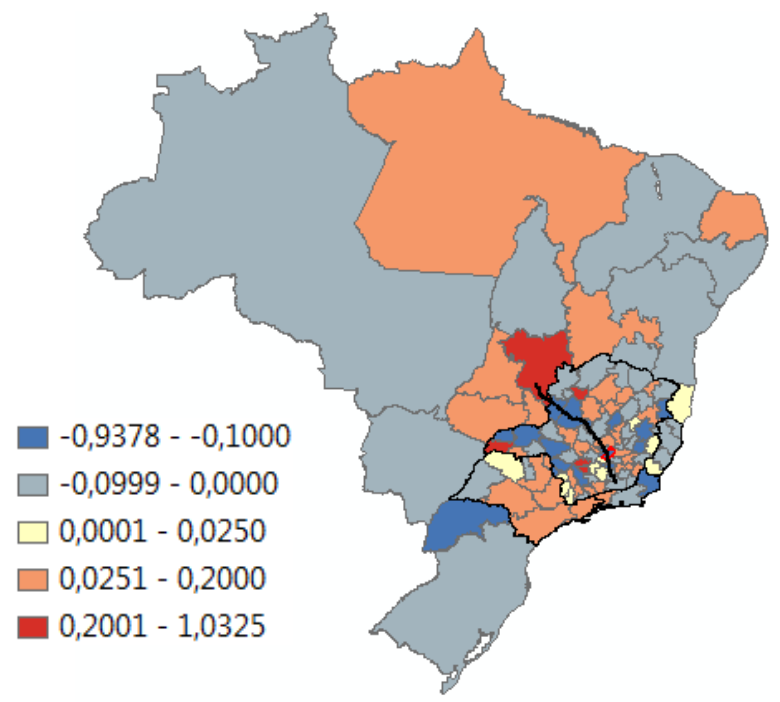

\section{Cenário 1}

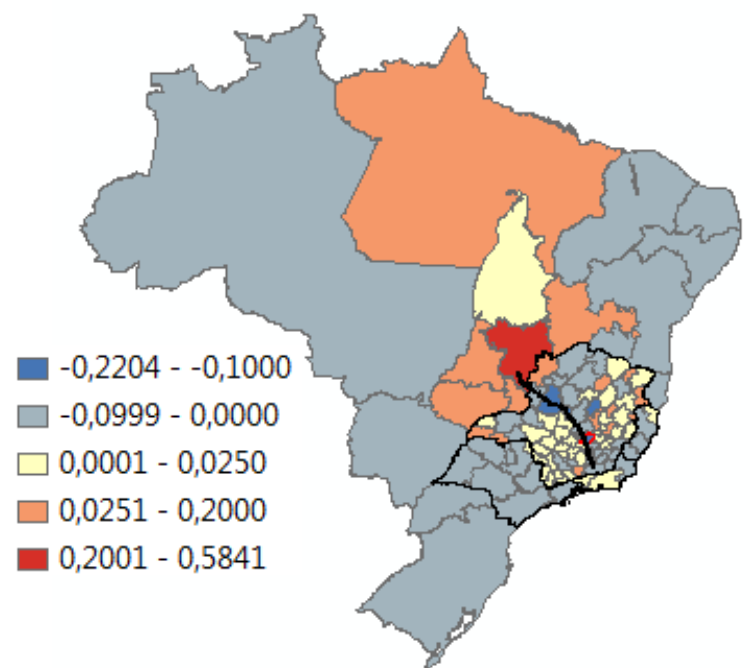

Cenário 3

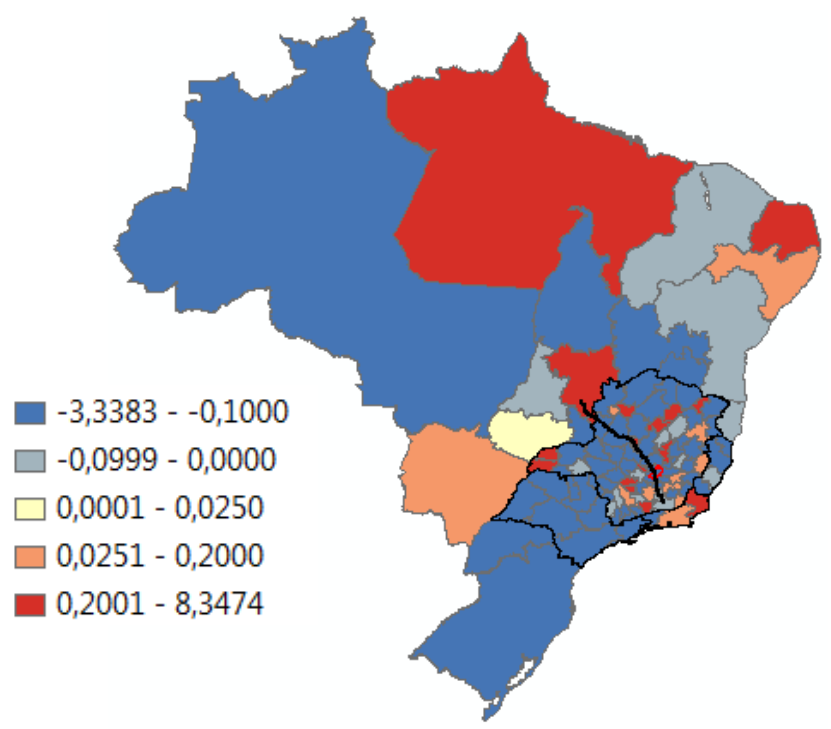

Figura 15 - Variação do consumo real das famílias

Nota: As legendas encontram-se em variação percentual

Fonte: Elaboração própria 
A seguir, serão avaliados os principais fatores estruturais que favorecem o crescimento do PIB das regiões nos cenários analisados.

\subsubsection{Análise estrutural do PIB regional}

Nesta seção serão avaliados quais os fatores estruturais que influenciam o PIB de determinada região a ser mais ou menos afetado pelas intervenções na rodovia BR-040. Tal análise é importante para entender por quais canais do modelo uma melhor eficiência do transporte afeta a economia. Na Tabela 9 a seguir, apresenta-se a estimativa dos principais fatores de impacto no PIB.

Tabela 9 - Análise estrutural dos resultados

\begin{tabular}{l|cccc} 
Variação do PIB & Cenário 0 & Cenário 1 & Cenário 2 & Cenário 3 \\
\hline $\begin{array}{l}\text { Índice de variação do custo de } \\
\text { transportes }\end{array}$ & 5,24 & 3,04 & 5,32 & 2,49 \\
& $(0,000)$ & $(0,000)$ & $(0,000)$ & $(0.069)$ \\
Compras de outras regiões & & & & \\
& $-0,349$ & $-0,183$ & $-0,279$ & $-0,323$ \\
& $(0,123)$ & $(0,301)$ & $(0,282)$ & $(0,446)$ \\
Vendas para outras regiões & 0,304 & 0,166 & 0,340 & 0,213 \\
& $(0,088)$ & $(0,155)$ & $(0,042)$ & $(0,482)$ \\
Participação do setor Outros & & & & $-0,480$ \\
Serviços na produção regional & $-1,169$ & $-0,695$ & $-1,270$ & $(0,368)$ \\
& $(0,002)$ & $(0,005)$ & $(0,003)$ & \\
Participação do setor Construção na \\
produção regional
\end{tabular}

Nota: p-valor em parênteses abaixo dos respectivos coeficientes

Fonte: Elaboração própria

Os resultados são relativamente estáveis em todos os cenários avaliados, sendo que o sinal é constante, mas, em algumas situações, os coeficientes perdem a significância estatística. $\mathrm{O}$ 
principal fator de influência na variação do PIB é a magnitude com que cada região é afetada pelas quedas nos custos de transportes, o que, neste trabalho, está sendo captado pelo índice de variação dos custos de transportes, explicado na seção 4.3.3 e exposto na Figura 12 e Figura 13. Esse resultado é esperado, uma vez que o principal choque que leva o sistema a mudar de equilíbrio é justamente o custo de transporte entre as distintas regiões. Outro fator que impacta positivamente a variação do PIB é a penetração dos produtos locais em outras regiões (vendas para outras regiões). Isso acontece, pois a redução no custo de transporte torna as firmas locais mais competitivas em outras regiões, tanto pelo acesso a insumos mais baratos, tornando-se mais produtivas, quanto pela redução do custo de levar seus produtos para outras regiões consumidoras. Devido à identidade das contas regionais, em que as exportações (inter-regionais ou internacionais) somam positivamente no PIB, o coeficiente da variável de venda para outras regiões é positivo. Já a variável que capta a parcela de compra de produtos de outras regiões, apesar de não apresentar significância estatística, possui um coeficiente negativo, o que também pode ser justificado pela identidade das contas regionais, onde a importação (de outras regiões ou do exterior) conta negativamente para o produto.

Com relação à produção regional, quanto maior a participação do setor de construção, menor o impacto das melhorias na BR-040 sobre o PIB, o que se deve ao fato de a elasticidade de Armington desse produto ser muito baixa, minimizando o efeito dos transportes interregionais no preço deste insumo. A participação do setor “outros serviços" também diminui o PIB para uma dada redução nos custos de transportes. Esses dois produtos pertencem à classe dos non-tradables, ou seja, produtos que são majoritariamente consumidos internamente à região produtora. Assim, quando sua participação na produção de determinada região é elevada, o local tem pouco a se beneficiar com a melhoria dos transportes inter-regionais, uma vez que são regiões que produzem muito para seus próprios consumidores. 


\section{CONSIDERAÇÕES FINAIS}

A infraestrutura de transporte, por influenciar diretamente o custo de deslocamento de mercadorias entre as distintas localidades do país, é um importante elemento para o desenvolvimento regional, sendo determinante para a decisão locacional das firmas da economia. Apesar dos indícios apontando para a importância desse tipo de ativo, o Brasil ainda é muito carente na oferta de infraestrutura de transportes e precisa tanto expandir, quanto melhorar a qualidade de sua malha rodoviária.

O marco regulatório recente do Brasil tem permitido uma participação cada vez maior do setor privado nos investimentos em infraestrutura, e, em particular, no setor rodoviário, o que se explica, entre outros fatores, pelas crescentes restrições orçamentárias enfrentadas pelo governo central. Nesse sentido, em 1995 e em 2004 foram editadas, respectivamente, a Lei das Concessões e a Lei das PPPs, regulamentando a atuação do setor privado como provedor de serviços públicos. Desde então, o setor de rodovias tem se valido dessa nova legislação e diversas estradas têm sido concedidas para a iniciativa privada, que custeiam os investimentos mediante a cobrança de pedágio dos usuários da rodovia.

Devido ao potencial de impacto econômico dos projetos de transporte é essencial avaliar $e x$ ante qual o efeito esperado para cada alternativa de projeto. Ainda, o investimento em rodovias financiado pelo usuário mediante o pagamento de pedágio gera um impacto nos custos de transporte entre os pares O-D distinto do impacto do mesmo investimento quando financiado por recursos orçamentários. Por esse motivo, a simples inserção de praças de pedágio pode gerar distorções na decisão locacional das firmas e na distribuição da atividade econômica. Esse aspecto ressalta a importância da avaliação ex-ante, não apenas dos impactos de um investimento em rodovias, mas também do impacto econômico esperado da forma como tal investimento será contratado e financiado.

Este trabalho buscou avaliar o impacto, de forma agregada e também regionalmente distribuído de se financiar o investimento, a operação e a manutenção de uma rodovia por meio da cobrança de pedágio dos seus usuários vis-à-vis seu financiamento pago pelas receitas orçamentárias do governo. De um lado, o usuário da rodovia, maior beneficiário de sua boa qualidade, é responsável por financiar seus custos, enquanto do outro, toda população se responsabiliza pelos custos das melhorias na rodovia. 
O foco do presente estudo centrou-se na origem dos recursos para o financiamento de rodovias (orçamento público contra financiamento pelos usuários da rodovia), de forma que outras variáveis importantes, dentre as quais se destacam a eficiência do setor público versus o setor privado, o custo de financiamento e a velocidade de execução das obras, não foram avaliadas. Dessa forma, a análise aproxima-se de uma comparação entre uma concessão comum com um modelo análogo ao "shadow toll", em que o setor privado opera a rodovia sendo remunerado por recursos orçamentários do governo.

Um trecho da rodovia BR-040, que liga Brasília a Juiz de Fora, foi selecionado para figurar como estudo de caso deste trabalho, uma vez que ele foi recentemente concedida à iniciativa privada para exploração por 30 anos. Para se avaliar a distribuição regional dos impactos de diferentes alternativas de financiamento de rodovias, utilizou-se o B-MARIA, um modelo inter-regional de equilíbrio geral computável operacional para a economia do Brasil, em conjunto com um modelo georreferenciado de transportes, por meio do qual se simulou uma melhora na qualidade da rodovia em análise. Foram feitas simulações tanto das melhorias sendo financiadas mediante a cobrança de pedágio dos usuários, quanto do cenário em que o governo financia o projeto por meio da elevação do imposto sobre os salários ou sobre as vendas do setor de transportes de toda a população.

Buscou-se avaliar qual o impacto das alternativas de financiamento da rodovia no PIB das 109 regiões do modelo e também seu valor de maneira agregada para o Brasil. Na análise agregada, a situação em que as melhorias na rodovia são financiadas pelos seus usuários mediante tarifas de pedágio mostrou-se a mais adequada, gerando um crescimento de PIB do país de $0,0128 \%$, valor levemente superior ao do cenário em que as melhorias são financiadas por uma elevação do imposto sobre os salários dos trabalhadores $(0,0122 \%)$. A situação de financiamento mediante a cobrança de tarifa das vendas de transporte mostrou-se pouco vantajoso para o país, causando uma queda de 0,0363\% de seu PIB.

Nos resultados regionalizados, percebe-se uma clara faixa de influências da BR-040 que vai de Belém (PA) até o Rio de Janeiro (RJ), passando pelo Tocantins, por Brasília (DF) e pelas regiões mineiras nos arredores da rodovia. A maioria das regiões dessa faixa de influência observou uma expansão de seu PIB, enquanto as regiões além das fronteiras dessa faixa tiveram seu PIB diminuído. Quando se passa de uma situação de financiamento das melhorias por meio de pedágio para uma de financiamento pela elevação de imposto sobre os salários, 
acontecem dois efeitos: (i) observa-se um estreitamento da faixa de regiões beneficiadas pelas melhorias na rodovia, pois as regiões mineiras nas fronteiras com São Paulo e com o Espírito Santo, que antes eram beneficiadas pelo projeto, passam a observar uma variação negativa do seu PIB; e (ii) acentua-se a diferença de crescimento entre as regiões beneficiadas e as prejudicadas, sendo que as primeiras são mais beneficiadas do que antes e as últimas acabam sendo ainda mais prejudicadas. O motivo dessa intensificação das diferenças regionais é que, após a inserção de um imposto sobre os salários, mesmo as regiões que não usufruem da rodovia acabam sendo parcialmente responsabilizadas pelo seu financiamento.

Este trabalho representa um primeiro passo no sentido de realizar uma avaliação ex-ante dos impactos econômicos regionalizados de um projeto de infraestrutura rodoviária levando em consideração questões contratuais e de financiamento. Foi delineada uma linha de análise que pode ser utilizada na comparação entre diferentes alternativas de financiamento de projetos de infraestrutura rodoviária, porém, a depender do interesse de cada pesquisador, tal linha de análise deve ser aprofundada para englobar questões mais específicas que se deseja explorar. Para pesquisas futuras sugere-se agregar à análise pontos ignorados nesta pesquisa, distanciando-se do cenário de "shadow toll" para levar em consideração as diferenças de eficiência na provisão dos serviços pelo setor público e pela iniciativa privada. Para tanto, é preciso primeiramente quantificar as diferenças de eficiência entre a gestão pública e privada dos ativos rodoviários, avaliando, por exemplo, alguns pontos que foram meramente mencionados no presente estudo, dentre os quais, a velocidade de execução das obras, a qualidade final da rodovia e seus impactos nos custos de transporte, o custo de financiamento de cada um dos agentes, entre outros. Quantificando cada um desses fatores, eles devem ser devidamente inseridos em seus respectivos cenários das simulações do modelo inter-regional de equilíbrio geral computável, para que novas simulações possam apontar os resultados esperados das diferentes alternativas de políticas. 


\section{REFERÊNCIA BIBLIOGRÁFICA}

ADAMS, Philip D. et al. Forecasts for the Australian economy using the MONASH model. International Journal of Forecasting, Australia 10(4), 557-571, 1994.

ALEXANDER, Ian; IRWIN, Timothy. Price Caps, Rate-of-Return Regulation, Risk and the Cost of Capital. The Private Sector on Infrastructure: Strategy, Regulation, and Risk. volume 1, 33-34, 1997.

ARGY, Fred et al. Infrastructure and Economic Development. CEDA Information Paper No 60, Melbourne: Committee for Economic Development of Australia, 1999.

ARROW, Kenneth J. The role of securities in the optimal allocation of risk-bearing. The Review of Economic Studies, p. 91-96, 1964.

ARVIS, Jean-François et al. Connecting to Compete 2014. Trade Logistics in the Global Economy: the Logistics Performance Index and Its Indicators. Washington DC, The World Bank, 2014.

ASCHAUER, David Alan. Is Public Expenditure Productive? Journal of Monetary Economics 23, 177-200, 1989.

ASCHAUER, David Alan. Public capital and economic growth: issues of quantity, finance, and efficiency. Economic Development and Cultural Change, 48(2), 391-406, 2000.

BERECHMAN, Joseph et al. Empirical analysis of transportation investment and economic development at state, county and municipality levels. Transportation, v. 33, n. 6, p. 537-551, 2006.

BLANC-BRUDE, Frédéric et al. Ex ante construction costs in the European road sector: a comparison of public-private partnerships and traditional public procurement. Economic and financial reports / European Investment Bank, No. 2006/01, 2006.

BOARNET, Marlon G. Spillovers and the locational effects of public infrastructure. Journal of Regional Science, v. 38, n. 3, p. 381-400, 1998. 
BOCCANFUSO, Dorothée et al. A comparative analysis of funding schemes for public infrastructure spending in Quebec. Applied Economics, v. 46, n. 22, p. 2653-2664, 2014.

BOLTON, Patrick; DEWATRIPONT, Mathias. Contract theory. MIT press, 2005.

BRASIL. Constituição da República Federativa do Brasil. Brasília, DF: Senado Federal, 1988.

. Ministério dos Transportes. Plano Nacional de Logística e Transporte. Brasília, 2010.

. Departamento Nacional de Infraestrutura de Transportes - DNIT. Apresentação institucional. Brasília, 2012a. Disponível em: <http://189.9.128.64/acesso-ainformacao/insitucional>. Acesso em: 02/04/2015.

Secretaria do Tesouro Nacional. O que você precisa saber sobre transferências constitucionais e legais: Cide - Combustíveis. Brasília, 2012b.

Ministério dos Transportes. Projeto de Reavaliação de Estimativas e Metas do PNLT: Relatório Final. Brasília, 2012c. Disponível em < http://www.transportes.gov.br/images/2014/11/PNLT/2011.pdf>. Acesso em: 11/08/2015.

Agência Nacional de Transportes Terrestres - ANTT. Programa de Exploração de Rodovias (PER). Anexo 2 do Edital de Concessão nº 006/2013. Brasília, 2013. Disponível em: < http://www.antt.gov.br/html/objects/_downloadblob.php?cod_blob=11775 >. Acesso em: 04/10/2015

Agência Nacional de Transportes Terrestres - ANTT. Histórico. Brasília, 2015a. Disponível em: < http://www.antt.gov.br/index.php/content/view/4978/Historico.html >. Acesso em: 29/04/2015.

Ministério do Planejamento. Brasília, 2015b. Disponível em < http://www.planejamento.gov.br/apresentacoes/apresentacoes-2015/rodovias-pil2015 >. Acesso em: 07/09/2015. 
BRAUETINGAM, Ronald R. Optimal Policies for Monopolies. In: SCHAMALENSE, Richard; WILlIG, Robert. (Org.). Handbook of Industrial Organization. Volume 2. Amsterdam: Elsevier Science Publishing Company, 1989.

CAMPOS NETO, Carlos Alvares da Silva; et al. Gargalos e demandas da infraestrutura rodoviária e os investimentos do PAC: Mapeamento Ipea de obras rodoviárias. Texto para Discussão, Instituto de Pesquisa Econômica Aplicada (IPEA), No. 1592, 2011.

CALDERÓN, César; SERVÉN, Luis. Infrastructure in Latin America. World Bank Policy Research Working Paper Series, Vol, 2010a.

The Effects of Infrastructure Development on Growth and Income Distribution in sub-Saharan Africa. Journal of African Economies, 19: i13-i187, $2010 \mathrm{~b}$.

CARDOSO, Adriana Bortolon Carvalho et al. Dinâmica dos ajustes contratuais em concessão de rodovias no estado de São Paulo. Revista de Administração Pública-RAP, v. 46, n. 5, p. 1295-1315, 2012.

CNT - Confederação Nacional dos Transportes. Pesquisa CNT de Rodovias 2014: relatório gerencial. Brasília, 2014.

DEMSETZ, Harold. Why regulate utilities? Chicago, EUA: Journal of Law and Economics, 11:55-65, 1968.

DE RUS, Gines; ROMERO, Manuel. Private financing of roads and optimal pricing: Is it possible to get both? The Annals of Regional Science, v. 38, n. 3, p. 485-497, 2004.

DEBREU, Gerard. The Theory of Value: An Axiomatic Analysis of Economic Equilibrium. New York: Wiley, 1959.

DIXON, Peter B.; PARMENTER, Brian R. Computable general equilibrium modelling for policy analysis and forecasting. In: AMMAN, Hans M. et al. .Handbook of computational economics. v. 1, p. 3-85. Amsterdam: Elsevier, 1996.

EBP - Empresa Brasileira de Projetos. Novas Projeções de tráfego: atualização da avaliação econômico-financeira. Produto 24 da $3^{\text {a }}$ etapa de concessões rodoviárias - fase 1 . Novembro, 2013. 
<http://www.ebpbrasil.com/ebp2014/web/download_arquivos.asp?id_arquivo=A1714FAA30CD-447A-83E5-1D67E52FF487> . Acesso em: 03/10/2015.

ENGEL, Eduardo et al. The economics of infrastructure finance: Public-private partnerships versus public provision. European Investment Bank Papers, 15(1), 40-69, 2010.

FAY, Marianne; MORRISON, Mary. Infrastructure in Latin America \& the Caribbean: Recent Developments and Key Challenges. The World Bank Finance, Private Sector and Infrastructure Unit, Latin America \& the Caribbean Region, Report No. 32640-LCR, The World Bank, Washinton DC, USA, 2005.

FERREIRA, Pedro Cavalcanti; MALLIAGROS, Thomas Georges. Impactos produtivos da infra-estrutura no Brasil-1950/95. Pesquisa e Planejamento Econômico, v.28, n.2, p.315$338,1998$.

FERREIRA, Tiago Toledo. Arranjos institucionais e investimentos em infraestrutura no Brasil. São Paulo, 2009. Dissertação (Mestrado em Economia) - Programa de Pós-graduação em Economia, Departamento de Economia, Faculdade de Economia, Administração e Contabilidade da Universidade de São Paulo.

FIPE. Estudo com Vistas a Subsidiar o Programa Estadual de Logística de Transporte do Estado de Minas Gerais. Governo do Estado de Minas Gerais, Belo Horizonte, 2007.

FRISCHTAK, Cláudio Roberto; DAVIES, Katharina. O investimento privado em infraestrutura e seu financiamento. In: PINHEIROS, Armando Castelar; FRISCHTAK, Cláudio Roberto. Gargalos e soluções na infraestrutura de transportes. $1^{\mathrm{a}}$ ed. Rio de Janeiro: Editora FGV, 2014.

FUJITA, Masahisa; THISSE, Jacques-Francois. Economics of Agglomeration. Cambridge, University Press, 2002.

GIESECKE, James et al. Regional macroeconomic outcomes under alternative arrangements for the financing of public infrastructure. Papers in Regional Science, 87: 3$31,2008$.

GRIMSEY, Darrin; LEWIS, Mervyn. Public private partnerships: The worldwide revolution in infrastructure provision and project finance. Edward Elgar Publishing, 2004. 
GÓMEZ-ANTONIO, Miguel; FINGLETON, Bernard. Analyzing the impact of public capital stock using the NEG wage equation: A spatial panel data approach. Journal of Regional Science, 52(3), 486-502, 2012.

GONZE, Nilson Corrêa. Concessão em rodovias federais: uma análise da evolução dos modelos de regulação técnica. Rio de Janeiro, 2014. Dissertação (mestrado) - Programa de Engenharia de Transportes, Instituto Alberto Luiz Coimbra de Pós-Graduação e Pesquisa de Engenharia da Universidade Federal do Rio de Janeiro.

GUASCH, J. Luis. Granting and renegotiating infrastructure concessions: doing it right. Washington DC, USA: The World Bank, 2004.

HADDAD, Eduardo Amaral. Regional Inequality and Structural Changes: lessons from the Brazilian Economy. Aldershot: Ashgate, 1999.

Retornos crescentes, custos de transporte e crescimento regional. São Paulo, 2004. Tese (Livre-Docência). Faculdade de Economia, Administração e Contabilidade da Universidade de São Paulo.

HADDAD, Eduardo Amaral et al. Avaliação dos impactos econômicos das políticas de infra-estrutura de transporte no Brasil: uma aplicação a duas rodovias federais em Minas Gerais. Cadernos do Banco de Desenvolvimento de Minas Gerais. Belo Horizonte, v.16, p. 29-74. Abril, 2008.

Regional Integration in Colombia: A Spatial CGE Application. Scienze Regionali / Italian Journal of Regional Science, v. 10, p. 5-30, 2011.

INVEPAR. Relatório anual 2013. 2013. Disponível em: < http://invepar.temp.w3br.com/midias/conteudo/pdf/Invepar_RA2013_PT_29set.pdf>.Acesso em: 07/09/2015.

JUSTEN FILHO, Marçal. As diversas configurações da concessão de serviço público. Revista de direito público da economia, p. 95-136, 2003.

KIM, Euijune et al. An Application of the Integrated Transport Network-Multi-regional CGE Model: An Impact Analysis of Government-Financed Highway Projects. Journal of Transport Economics and Policy, 223-245, 2011. 
KRUGMAN, Paul. What's new about the new economic geography? Oxford review of economic policy, 14(2), 7-17, 1998.

LACERDA, Sander Magalhães. O financiamento da infra-estrutura rodoviária através de contribuintes e usuários. BNDES Setorial, Rio de Janeiro, n. 21, p. 141-159, 2005.

MAS-COLELL, Andreu et al. Microeconomic theory (Vol. 1). New York: Oxford University Press, 1995.

MEIRELLES, Hely Lopes. Licitação e Contratos Administrativos. 14a Edição - Editora Malheiros, 2006.

MELO, Patricia C. et al. The productivity of transport infrastructure investment: A metaanalysis of empirical evidence. Regional Science and Urban Economics, 43(5), 695-706, 2013.

MOUGEOT, Michel; NAEGELEN, Florence. Franchise bidding, regulation and investment costs. Review of Economic Design, v. 15, n. 1, p. 37-58, 2011.

MUSSOLINI, Caio Cesar; TELES, Vladimir Kühl. Infraestrutura e produtividade no Brasil. Revista de Economia Política, vol. 30, no 4 (120), pp. 645-662, outubro-dezembro, 2010 .

NEWBERY, David M. Road pricing and road finance. In: PRESTON John et al. Integrated transport policy: Implications for regulation and competition. Aldersho. Ashgate, 2000.

NEWBERY, David M. Road user and congestion charges. Theory and Practice of Excise Taxation: Smoking, Drinking, Gambling, Polluting, and Driving. Oxford University Press, Oxford, 193-229, 2005.

NICHOLSON, Walter; SNYDER, Christopher. Microeconomic Theory. South Western/Thomson, Tenth Edition, 2005.

OTTAVIANO, Gianmarco. Infrastructure and economic geography: An overview of theory and evidence. European Investment Bank Papers, ISSN 0257-7755, Vol. 13, Iss. 2, pp. 8-35, 2008. 
PERCOCO, Marco. Infrastructure Investment and Growth in Developing Countries: Does the Type of Contract Matter?. Journal of Infrastructure Development, 4(2), 139-152, 2012.

PEREIRA, Ricardo A. de Castro; FERREIRA, Pedro Cavalcanti. Impactos macroeconômicos da cobrança pelo uso da infraestrutura pública no Brasil. Pesquisa e Planejamento Econômico, v. 41, n. 2, p. 183-212, 2011.

PINTO, Henrique Motta; ROSILHO, André Janjácomo. Reforma da Administração Pública. Mudanças nas licitações: a inversão de fases e o saneamento de falhas no STF. 2008. Disponível em: <http://www.sbdp.org.br/observatorio_ver.php?idConteudo=13>. Acesso em: 12/05/2015.

PUGA, Diego. The rise and fall of regional inequalities. European Economic Review 43(2):303-334, 1999.

PUGA, Diego. European Regional Policies in Light of Recent Location Theories. Journal of Economic Geography 2, 373-406, 2002.

RIBAULT, Anne. Lessons from the French experience in public and private partnership. Irish Banking Review, p. 49-60, 2001.

ROBERTS, Mark et al. On the Road to Prosperity? The Economic Geography of China's National Expressway Network. World Bank Policy Research Series WPS5479, 2010.

SÁ, Adolfo Luiz Souza et al. Contratos de eficiência no regime diferenciado de contratações públicas: uma inovação a ser aplicada na gestão das infraestruturas de transportes. In: XXVII Congresso de Pesquisa e Ensino em Transportes. Belém, 2013.

SALA-I-MARTÍN, Xavier et al. The Global Competitiveness Index 2014-2015: Accelerating a Robust Recovery to Create Productive Jobs and Support Inclusive Growth The Global Competitiveness Report 2014-2015 (Editor: Klaus Schwab). World Economic Forum Publication, Geneva, 2014.

SCHWIND, Rafael Wallbach. Remuneração variável e contratos de eficiência no Regime Diferenciado de Contratações Públicas. In: JUSTEN FILHO, Marçal; PEREIRA, Cesar A. Guimarães. (coordenadores). O Regime Diferenciado de Contratações Públicas (RDC): comentários à Lei n 12.462 e ao Decreto nº 7.581. Fórum, Belo Horizonte, 2012. 
SOUZA, Gedir Silva et al. Política fiscal e crescimento de longo prazo no Brasil: evidências para dados do orçamento função. Pesquisa e Planejamento Econômico, v. 40, n. 1, p. 41-84, abr. 2010.

VON NEUMANN, John; MORGENSTERN, Oskar. Theory of Games and Economic Behaviour. Princeton, NJ: Princeton University Press, 1944.

WILLIAMSON, Oliver E. Franchise bidding for natural monopolies-in general and with respect to CATV. The Bell Journal of Economics, p. 73-104, 1976. 


\section{APÊNDICE A - CRESCIMENTO POR REGIÃO}

Tabela 10 - Crescimento do PIB por região

\begin{tabular}{|c|c|c|c|c|}
\hline & Cenário 0 & Cenário 1 & Cenário 2 & Cenário 3 \\
\hline |Unaí & 0,70519 & 0,51477 & \begin{tabular}{|l|l|}
0,65204 \\
\end{tabular} & 0,5706 \\
\hline $\begin{array}{l}2 \text { Paracatu } \\
\end{array}$ & 0,65215 & 0,36772 & 0,53737 & 0,27943 \\
\hline 3 Januaria & 0,07112 & 0,04555 & 0,02546 & $-0,07929$ \\
\hline \begin{tabular}{l|l} 
Janauba \\
\end{tabular} & 0,09665 & 0,06463 & 0,07667 & $-0,05628$ \\
\hline${ }_{5}$ Salinas & 0,09794 & 0,06523 & 0,06168 & $-0,13221$ \\
\hline \begin{tabular}{|l|l|}
6 & Pirapora \\
\end{tabular} & 0,30823 & 0,20919 & 0,34179 & $-0,08854$ \\
\hline Montes Claros & 0,03277 & 0,02018 & 0,04952 & $-0,03156$ \\
\hline \begin{tabular}{l|l}
8 Grão Mogol \\
\end{tabular} & 0,34962 & 0,23315 & 0,39039 & 1,16877 \\
\hline Bocaiuva & 0,12757 & 0,08499 & 0,23033 & 0,40303 \\
\hline${ }_{10}$ Diamantina & 24744 & 0,17395 & 0,21282 & 0,24338 \\
\hline "Capelinha & $-0,00742$ & $-0,00253$ & 0,0183 & $-0,1271$ \\
\hline 12. Aracuai & 0,09105 & 0,06114 & 0,08166 & $-0,05425$ \\
\hline $\begin{array}{l}13 \text { Pedra Az } \\
\end{array}$ & 0,06545 & 0,0447 & 0,05483 & $0,09 c$ \\
\hline \begin{tabular}{l|l|} 
Af Almenara \\
\end{tabular} & 0,04283 & 0,02605 & $-0,02281$ & $-0,13494$ \\
\hline \begin{tabular}{l|l|l}
15 & Teofilo Otoni
\end{tabular} & 0,01506 & 0,00428 & 0,04141 & 0,01676 \\
\hline \begin{tabular}{l|l|}
16 & Nanuqu \\
\end{tabular} & 0,04319 & 0,02838 & $-0,5054$ & $-1,84292$ \\
\hline$\pi \mid$ Ittuiutaba & 0,02819 & 0,01676 & $-0,14642$ & 1,92156 \\
\hline \begin{tabular}{l|l|l|}
18 & Uberlândia \\
\end{tabular} & $-0,01162$ & $-0,00735$ & $-0,07698$ & $-0,19285$ \\
\hline 19 Patrocínio & 0,02039 & 0,01201 & \begin{tabular}{ll|}
0,01027 \\
\end{tabular} & $-0,08878$ \\
\hline${ }_{20}$ Patos de Min & 0,11044 & 0,01462 & 0,12755 & $-0,01033$ \\
\hline 21. Frutal & 0,01838 & 0,01255 & 0,03318 & $-0,67788$ \\
\hline $\begin{array}{ll}22 & \text { Uberaba } \\
\end{array}$ & 0,0004 & 0,00108 & $-0,04219$ & $-0,04915$ \\
\hline 23 Araxa & 0,06268 & 0,0362 & $-0,24921$ & $-0,93284$ \\
\hline${ }_{24}$ Três Marias & 0,78099 & 0,48888 & 0,68175 & 1,16625 \\
\hline \begin{tabular}{l|l|l|}
${ }_{25} 5$ & Curvelo \\
\end{tabular} & 0,16547 & 0,07454 & 0,16795 & $-0,48482$ \\
\hline \begin{tabular}{l|l|}
26 & Bom Despacho
\end{tabular} & 0,04142 & 0,02501 & 0,06938 & $-0,099$ \\
\hline \begin{tabular}{|l|l}
27 & Sete Lagoas
\end{tabular} & 0,05421 & 0,01845 & 0,08015 & $-0,03673$ \\
\hline \begin{tabular}{l|l}
${ }_{28} 8$ Conceiçãa \\
\end{tabular} & 0,08274 & 0,05328 & \begin{tabular}{|l|l|l|}
0,14413 \\
\end{tabular} & \\
\hline${ }_{29}$ Pará de Mir & 0,13156 & 0,08359 & 0,19986 & 0,540 \\
\hline \begin{tabular}{l|l}
30 & Belo Hor
\end{tabular} & 0,00593 & 0,0158 & $-0,0089$ & $-0,048$ \\
\hline 3| Itabira & 0,14107 & 0,09329 & 0,17259 & $-0,120$ \\
\hline $\begin{array}{l}32 \\
32 \text { Itaguai } \\
\end{array}$ & 0,10374 & 0,06905 & 0,09724 & $-0,10389$ \\
\hline \begin{tabular}{l|l}
${ }_{35}$ & Ouro Preto \\
\end{tabular} & 0,22745 & 0,02504 & 0,2687 & \\
\hline \begin{tabular}{l|l}
${ }_{34}$ Conselheiro Lafaiete \\
\end{tabular} & 0,20562 & 0,05482 & 0,18056 & $-0,28$ \\
\hline \begin{tabular}{l|l}
35 & Guanhaes \\
\end{tabular} & 0,0488 & 0,03145 & $-0,01595$ & $-0,27018$ \\
\hline $\begin{array}{l}36 \\
36\end{array}$ & 0,09833 & 0,06493 & 0,07082 & $-0,104$ \\
\hline \begin{tabular}{l|l}
$3 r$ Governador Valadares \\
3
\end{tabular} & 0,00858 & 0,00131 & $-0,40225$ & \\
\hline $\begin{array}{l}38 \\
38 \text { Mantena } \\
\end{array}$ & 0,05529 & 0,03847 & 0,00504 & -0, \\
\hline 39|lpating & 0,04948 & 0,03839 & 0,05741 & 0,049 \\
\hline
\end{tabular}

\begin{tabular}{|c|c|c|c|c|}
\hline & Cenário 0 & Cenário 1 & Cenário 2 & Cenário 3 \\
\hline${ }_{40}$ Caratinga & 0,01001 & 0,00574 & $-0,26128$ & $-1,05443$ \\
\hline \$1 Aimores & 0,01693 & 0,01208 & 0,01548 & 0,00531 \\
\hline${ }_{42}$ Piui & 0,02193 & 0,01428 & $-0,0519$ & $-0,91911$ \\
\hline \begin{tabular}{l|l|}
${ }_{43}$ & Divinópolis \\
\end{tabular} & 0,08335 & 0,05126 & 0,07576 & 0,01658 \\
\hline $\begin{array}{l}44 \text { Formiga } \\
\end{array}$ & 0,03128 & 0,02129 & 0,17073 & 1,39674 \\
\hline \begin{tabular}{l|l}
45 & Campo Belo \\
\end{tabular} & 0,03604 & 0,0225 & 0,28336 & 0,79078 \\
\hline $\begin{array}{ll}46 & \text { Oliveira } \\
\end{array}$ & 0,04917 & 0,03324 & 0,04079 & $-0,27684$ \\
\hline $\begin{array}{ll}47 & \text { Passos } \\
\end{array}$ & $-0,00862$ & $-0,0053$ & $-0,10512$ & $-0,57185$ \\
\hline${ }_{44}^{4} \mid$ São Sebastião do Paraíso & 0,00675 & 0,00288 & $-0,55524$ & $-1,20886$ \\
\hline $\begin{array}{lll}49 & \text { Alfenas } \\
\end{array}$ & $-0,00765$ & $-0,00448$ & $-0,0103$ & $-0,05314$ \\
\hline sol Varginha & $-0,02859$ & $-0,01853$ & $-0,10435$ & 0,00027 \\
\hline sil Poços de Caldas & $-0,01558$ & $-0,00897$ & $-0,02794$ & $-0,12069$ \\
\hline \begin{tabular}{|l|l|}
522 & Pouso Alegre \\
\end{tabular} & $-0,00174$ & $-0,00164$ & $-0,01529$ & $-0,09351$ \\
\hline 53 Santa Rita do Sapucaí & 0,01617 & 0,01192 & 0,0025 & $-0,09129$ \\
\hline \begin{tabular}{l|l} 
s44 $^{4}$ São Lourenço \\
\end{tabular} & 0,01816 & 0,01287 & 0,03063 & $-0,07818$ \\
\hline 55. Andrelândia & 0,08913 & 0,05531 & 0,1109 & 0,497 \\
\hline $\begin{array}{l}56 \\
56\end{array}$ & 0,05083 & 0,03707 & 0,00287 & $-0,07462$ \\
\hline $\begin{array}{ll}77 & \text { Lavras } \\
\end{array}$ & 0,00886 & 0,0009 & 0,01039 & $-0,04364$ \\
\hline s8 São João del Rei & 0,05141 & 0,02666 & 0,04664 & 0,05011 \\
\hline $\begin{array}{l}59 \\
59 a r b a c e n a \\
\end{array}$ & 0,05075 & 0,04029 & 0,04027 & 0,05807 \\
\hline \begin{tabular}{l|l|}
${ }_{60}$ & Ponte Nova \\
\end{tabular} & 0,08223 & 0,03876 & 0,09073 & 0,11424 \\
\hline 6il Manhuçu & $-0,00466$ & $-0,00184$ & $-0,01366$ & $-0,08724$ \\
\hline \begin{tabular}{l|l}
62 & Viscosa \\
\end{tabular} & 0,061 & 0,03206 & 0,08007 & 0,06427 \\
\hline${ }_{63}$ Muriae & 0,05989 & 0,0361 & 0,07964 & $-0,06884$ \\
\hline \begin{tabular}{ll|l}
64 & Uba \\
\end{tabular} & 0,05483 & 0,03621 & 0,05334 & 0,01685 \\
\hline \begin{tabular}{l|l|}
65 & Juiz de Fora \\
\end{tabular} & 0,05394 & 0,01578 & 0,04233 & 0,01231 \\
\hline \begin{tabular}{l|l|}
${ }_{66} 6$ & Cataguases \\
\end{tabular} & 0,0765 & 0,04865 & 0,05989 & 0,0804 \\
\hline \begin{tabular}{l|l}
67 Iturama \\
\end{tabular} & 0,01807 & 0,01326 & 0,27916 & 1,90771 \\
\hline \begin{tabular}{l|l|}
68 Abaete \\
\end{tabular} & 0,07722 & 0,04886 & 0,08974 & $-0,083$ \\
\hline 69 Jão Pinheiro & 0,73129 & 0 & 0,71585 & 0,33719 \\
\hline ro|Bonfinópolis de Minas & 0,31833 & 0,22824 & 0,3381 & 0,4479 \\
\hline "1|São Romão & 0,11708 & 0,07857 & 0,52417 & 0,30588 \\
\hline Ta Betim & 0,52367 & 0,34652 & 0,52296 & 0,51211 \\
\hline \begin{tabular}{l|l|}
73 & Vespasiano \\
\end{tabular} & 0,10224 & 0,07073 & 0,10688 & $-0,0317$ \\
\hline $7_{74}$ João Monlevade & 0,05926 & 0,0372 & 0,08244 & $-0,37241$ \\
\hline $\begin{aligned} 75 \\
\text { Guaxupe }\end{aligned}$ & $-0,02269$ & $-0,01359$ & $-0,04165$ & 0,12825 \\
\hline 76 Barreiras & 0,164 & 0,13165 & 0,15521 & 0,08654 \\
\hline$m$ Brumado & $-0,01758$ & $-0,01212$ & $-0,01503$ & $-0,28728$ \\
\hline Ts Salvador & $-0,01677$ & $-0,0110$ & & \\
\hline
\end{tabular}

\begin{tabular}{|c|c|c|c|c|}
\hline & Cenário 0 & nário 1 & Cenário 2 & enário 3 \\
\hline $\begin{array}{l}{ }_{79} \\
\text { Porto Seguro }\end{array}$ & $-0,0249$ & $-0,01469$ & $-0,03206$ & $-0,02905$ \\
\hline so Aracaju & $-0,00774$ & $-0,00807$ & $-0,00439$ & $\mid-0,01302$ \\
\hline 81 Natal & 0,00709 & $-0,00395$ & 0,08166 & 0,44728 \\
\hline \begin{tabular}{l|l|}
82 & Fortaleza \\
\end{tabular} & $-0,00731$ & $-0,00827$ & $-0,00686$ & $-0,02721$ \\
\hline \begin{tabular}{l|l|l|}
83 & Belém \\
\end{tabular} & 0,07773 & 0,05595 & 0,09789 & 0,20575 \\
\hline${ }_{84}$ Colatina & 0,00313 & 0,00357 & 0,00593 & $-0,26183$ \\
\hline $\begin{array}{l}85 \\
85 a ̃ o \\
\end{array}$ & 0,01672 & 0,01164 & $-0,02409$ & \begin{tabular}{|l|}
$-0,36842$ \\
\end{tabular} \\
\hline $\begin{array}{l}86 \\
8 \text { Vitória } \\
\end{array}$ & 0,00261 & 0,00366 & $-0,01863$ & $-0,05618$ \\
\hline $\begin{array}{l}87 \text { Cachoeira do Itapemirim } \\
\end{array}$ & 0,0078 & 0,00746 & 0,0175 & $-0,25445$ \\
\hline \begin{tabular}{l|l|}
88 & Compos de Goytacazes \\
8
\end{tabular} & 0,02107 & 0,01403 & 0,11534 & $\mid-0,22101$ \\
\hline $\begin{array}{l}9 \\
\text { Ryio de Janeiro }\end{array}$ & 0,03848 & 0,02398 & 0,02893 & $-0,02724$ \\
\hline${ }_{901} \mid$ Volta Redonda & 0,04135 & 0,02596 & 0,05281 & $-0,16572$ \\
\hline צn| São José do Rio Preto & $-0,02136$ & $-0,01176$ & $-0,02568$ & $-0,04984$ \\
\hline \begin{tabular}{l|l}
${ }_{92}$ & Ribeirão Preto \\
\end{tabular} & $-0,01619$ & $-0,00725$ & $-0,00357$ & $-0,06096$ \\
\hline${ }_{3 s}$ Barretos & $-0,00985$ & $-0,0027$ & $-0,01749$ & $-0,0478$ \\
\hline \begin{tabular}{l|l|}
94 & Franca \\
\end{tabular} & 0,00604 & 0,00869 & $-0,00631$ & $-0,02164$ \\
\hline $\begin{array}{l}{ }_{95} \\
\text { Araçatuba } \\
\end{array}$ & $-0,02161$ & $-0,0122$ & $-0,02756$ & \begin{tabular}{|l|}
$-0,05407$ \\
\end{tabular} \\
\hline \begin{tabular}{l|l|}
96 & Bauru \\
\end{tabular} & $-0,02688$ & $-0,01511$ & $-0,0285$ & $-0,05675$ \\
\hline $\begin{array}{ll}\text { gr } & \text { Campinas } \\
\end{array}$ & $-0,01443$ & $-0,00596$ & $-0,01773$ & $-0,05094$ \\
\hline $\begin{array}{ll}\text { So } & \text { São Paulo }\end{array}$ & $-0,00831$ & $-0,00225$ & $-0,0095$ & $-0,04219$ \\
\hline \begin{tabular}{l|l|l|}
99 & Santos \\
\end{tabular} & $-0,01028$ & $-0,00426$ & $-0,00961$ & $-0,05294$ \\
\hline 100 Taubaté & $-0,00975$ & $-0,00285$ & $-0,01363$ & $-0,04816$ \\
\hline 1011 Maringa & $-0,02659$ & \begin{tabular}{l|l}
$-0,01626$ \\
\end{tabular} & $-0,05797$ & $-0,11715$ \\
\hline $\begin{array}{ll}102 & \text { Curitiba } \\
\end{array}$ & $-0,02135$ & $-0,01218$ & $-0,03693$ & $-0,06304$ \\
\hline $\begin{array}{lll}103 & \text { Goiânia } \\
\end{array}$ & 0,17023 & 0,13573 & 0,1644 & 0,12835 \\
\hline \begin{tabular}{l|l}
${ }_{104}$ & Rio Verde \\
\end{tabular} & 0,10739 & \begin{tabular}{l|l}
0,08565 \\
\end{tabular} & 0,09782 & 0,06933 \\
\hline 105 Catalão & 0,14899 & 0,11959 & 0,14424 & \begin{tabular}{|l|}
0,08989 \\
\end{tabular} \\
\hline \begin{tabular}{l|l|l|}
106 & Brasilia \\
\end{tabular} & 0,52676 & 0,42301 & 0,5324 & 0,54545 \\
\hline 100 Campo Grande & $-0,0262$ & $-0,015$ & $-0,02671$ & $-0,07292$ \\
\hline \begin{tabular}{l|l|l|}
108 & Palmas \\
\end{tabular} & 0,10243 & 0,07856 & 0,09425 & 0,01106 \\
\hline $\begin{array}{ll}109 & \text { Cuiabá } \\
\end{array}$ & $-0,00284$ & $-0,00227$ & 0,00076 & $-0,05851$ \\
\hline
\end{tabular}

